\title{
Plants, animals and formulae : natural history in the light of Latour's Science in action and Foucault's The order of things
}

Citation for published version (APA):

Stemerding, D. (1991). Plants, animals and formulae : natural history in the light of Latour's Science in action and Foucault's The order of things. [Doctoral Thesis, Maastricht University]. Universiteit Twente. https://doi.org/10.26481/dis.19910117ds

Document status and date:

Published: 01/01/1991

DOI:

10.26481/dis.19910117ds

Document Version:

Publisher's PDF, also known as Version of record

Please check the document version of this publication:

- A submitted manuscript is the version of the article upon submission and before peer-review. There can be important differences between the submitted version and the official published version of record.

People interested in the research are advised to contact the author for the final version of the publication, or visit the DOI to the publisher's website.

- The final author version and the galley proof are versions of the publication after peer review.

- The final published version features the final layout of the paper including the volume, issue and page numbers.

Link to publication

\footnotetext{
General rights rights.

- You may freely distribute the URL identifying the publication in the public portal. please follow below link for the End User Agreement:

www.umlib.nl/taverne-license

Take down policy

If you believe that this document breaches copyright please contact us at:

repository@maastrichtuniversity.nl

providing details and we will investigate your claim.
}

Copyright and moral rights for the publications made accessible in the public portal are retained by the authors and/or other copyright owners and it is a condition of accessing publications that users recognise and abide by the legal requirements associated with these

- Users may download and print one copy of any publication from the public portal for the purpose of private study or research.

- You may not further distribute the material or use it for any profit-making activity or commercial gain

If the publication is distributed under the terms of Article $25 \mathrm{fa}$ of the Dutch Copyright Act, indicated by the "Taverne" license above, 


\section{PLANTS, ANIMALS AND FORMULAE}

Natural history in the light of Latour's Science in Action
and Foucault's The Order of Things

\section{Proefschrift}

ter verkrijging van de graad van doctor aan de Rijksuniversiteit Limburg te Maastricht, op gezag van de Rector Magnificus, Prof. Mr. M. J. Cohen, volgens het besluit van het College van Dekanen, in het openbaar te verdedigen op donderdag, 17 januari 1991, om 14.00 uur

door

Dirk Stemerding geboren te Amsterdam 


\section{Promotores}

Prof. Dr. L. Boon

Prof. Dr. Ir. G. H. de Vries

\section{Co-promotor}

Dr. R. P. W. Visser

\section{Beoordelingscommissie}

Prof. Dr. H. Philipsen

Prof. Dr. K. van Berkel

Dr. J. J. H. Dekker

Mw. Dr. A. Mol

Prof. Dr. A. Rip 


\section{(C) 1991 Dirk Stemerding}

School of Philosophy and Social Sciences, University of Twente, Enschede, The Netherlands.

All rights reserved. No part of this publication may be reproduced, stored in a retrieval system, or transmitted, in any form or by any means, electronic, mechanical, photocopying, recording, or otherwise, without the prior written permission of the publisher.

ISBN $\quad 90-365-0379-5$

Vormgeving en Productie: VIDEAC, Universiteit Twente Druk: Reproductiedienst, Universiteit Twente 

soms wat doelloos dobberen

- ont-roerd.

of gewoon zinloos zwabberen

lijht het

maar witeindelijk

"het roer recht"

en op koers

PREFACE

A.v.d.M.

In 1980, I started out at the "Boerderij", the Centre for Studies of Science, Technology and Society at the University of Twente, in a spirit of intellectual adventure. Now, looking back upon a long period of often intense work, I must admit that in some respects I got more than I bargained for. In the course of wandering around in the history of biology and at the same time struggling with the particulars of Piaget's genetic epistemology, a project emerged of which I increasingly felt that it was a bit too much of an adventure. Yet what remained was a fascination with an historical period in which those who studied plants and animals were called "naturalists" and in which "biology" was only just becoming a catchword, introduced by those who dreamed about a real science of "life". What further remained was a fascination with grand theoretical frames capable of ordering a multitude of historical events. Ultimately, I experienced the pleasure of finding a way to combine these fascinations into a single book. It is first of all this sense of pleasure which, through this dissertation, I would like to pass on to the reader.

Most important in seducing me to both the pleasures and dangers of intellectual adventure was my teacher and friend Peter Boskma. His unflagging trust in my ability to bring even difficult matters to an happy end was not always justified but nevertheless of incalculable value for my personal and intellectual development. After Peter's death in 1986, I found Louis Boon en Gerard de Vries willing to take over his mentorship and see the project through to completed manuscript. The fact that $I$ had to overcome their initial scepticism turned out to be a great help to me and I felt highly stimulated by their subsequent support. For advice on historical matters, I was always able to turn to Rob Visser and I am most grateful to him for his patience and for never discouraging me in the pursuit of my sometimes all too excessive ambitions. 
Intellectual adventure is often a lonely adventure. I think this dissertation would never have been written if at some of the moments of greatest loneliness I had not had the support of my colleagues and friends at the "Boerderij". I particularly remember one summer evening in 1985, when Wiebe Bijker and Jaap Jelsma gave me a crucial push in some (I can no longer remember which) direction. In the years that followed, Wim Smit, Ellen van Oost, Geert Vissers, and Jaap Jelsma often kept me going by reading and discussing what I was writing. Insofar as all this was not enough, Ellen van Oost helped me by simply enduring my grumbly moods.

The transformation of my story into a real and readable book has been greatly facilitated by Nil Disco and Arie Rip, who kept me from many "faux pas" in the use of the English language; by Marita Wesselink of Videac, who did a perfect job in composing the text; and by Ellen van Oost, who designed the cover.

Finally, I want to thank Mrs. Christiane Baradel for tracing and carefully copying some old memoirs on seemingly bizarre subjects like the classification

of worms, Maud Defay for her hospitality during the week which $I$ spent in Paris visiting the Bibliotheque nationale, and Lian Hylkema for her ever-cheerfull assistance when I tried to find my way in the library of the Biohistorisch Instituut in Utrecht. 


\section{CONTENTS}

Introduction. 11

part one

Chapter I Natural history. 23

Chapter II Linnaeus and Buffon. 43

Chapter III Sociologics or logic? 85

part two

Chapter IV Natural history transformed. 105

Chapter V Cuvier and Geoffroy. 133

Chapter VI The relativity of change. 171

Bibliography. 189

Samenvatting. 195 



\section{INTRODUCTION}

\section{Foucault and the history of biology}

In a discussion of the particular problems of the history of eighteenth-century life science, the French historian of science Jacques Roger has emphasized an intellectual revolution which, since the 1950's, has deeply affected the study of the history of science. ${ }^{1}$ According to the perspective which dominated the history of science in the first half of the twentieth century, eighteenth-century science was "modern science in the cradle". That is, science was supposed to progress continuously, from discovery to discovery, through a simple process of accumulation in which more and more facts were added to the fund of scientific knowledge. However, as Roger points out, progress is no longer the key-word in history. What actually appeared, in his view, was a new philosophy of history, in which continuity was replaced by discontinuity. To illustrate this point, Roger mentions two books, namely, Thomas Kuhn's The Structure of Scientific Revolutions and Michel Foucault's The Order of Things. In both works the history of science is considered as a discontinuous series of isolated periods, whereby each period is characterized by a particular framework - a "paradigm" or "episteme" - within which, as Roger puts it, "human thought had to work".

Foucault's work is especially interesting for the historian of biology, because a major theme in The Order of Things is a discussion of some fundamental discontinuities which characterize the history of our modern science of life. ${ }^{2}$ In Foucault's opinion any historian attempting to write a history of biology in the eighteenth century clearly attempts the impossible. Biology, in his view, did not exist then, simply because "life itself" did not exist. What existed in the eighteenth century was natural history as a science in which all natural objects plants, animals and stones - were described and classified. Indeed, natural history was not "biology in the cradle", but represented, in the eyes of Foucault, a radically different mode of thought, or what he calls, a classical episteme.

According to Foucault, this classical episteme characterized a distinct historical epoch, bounded by two great discontinuities in the history of Western culture, the first roughly half-way through the seventeenth century, the second at the beginning of the nineteenth century. In this epoch the multifarious and 
hidden bonds between words and things, which were typical for the knowledge of the Renaissance, had been broken. Instead, words could only represent the things and what made possible this representation was a system of signs which allowed things to be ordered, to be classified in terms of visible identities and differences. Thus, the classical episteme revealed itself in the appearance of a general science of classification and natural history was one of the manifestations of this science. However, natural history not only emerged half-way through the seventeenth century as a result of a radical transformation of the then prevalent forms of thought, it also made way for a biology at the end of the eighteenth century as a result of another, no less radical change of thought. That is, at the end of the eighteenth century, there emerged a new mode of thought, a modern episteme which, according to Foucault, was revealed by a sudden shift of the gaze from visible, outward identities and differences between forms to the hidden, internal, functional characteristics of living beings. So, early in the nineteenth century, biology was constituted as a new science of life.

Foucault is by no means the only one who has traced the origin of a modern science of life to the early nineteenth century. Authors on the history of biology generally tend to perceive the early nineteenth century as a crucial period, somehow relating it to themes like the "end of natural history", the origin of a "history of nature", or more in general, the emergence of "biology" as a true science of life. ${ }^{3}$ Moreover, some authors have attempted to expand Foucault's analysis of discontinuities in the history of thought to domains narrowly related to that of classical natural history. For example, in an analysis of the development of mineral studies from the Renaissance to the beginning of the nineteenth century, Albury and Oldroyd have pointed out some radicall shifts in the way minerals were studied which correspond with the scheme presented by Foucault. ${ }^{4}$ In another study, Albury has compared Bichat's physiology at the end of the eighteenth century to the physiology of Magendie in the first half of the nineteenth century. In his view, these physiologies too, reveal radically different "problematics", one characteristic of the episteme of the so-called classical period, the other of a new episteme of organic functions which, according to Foucault's analysis, became the foundation of biology as a science of life. ${ }^{5}$

Thus, the new philosophy of history to which Jacques Roger referred in his reflections upon the history of science, can indeed be sensed in the writings of many authors on the history of biology, and for some of these authors Foucault's work obviously has been a source of inspiration. ${ }^{6}$ A most typical reaction to Foucault's work is probably Burkhardt's observation that historians may debate the validity of Foucault's generalization, but that "it cannot be denied that the basic concern of the eighteenth-century naturalist differed from that of the nineteenth-century biologist" ${ }^{7}$ In other words, in the eyes of historians of 
biology, Foucault's analysis in The Order of Things is perhaps not altogether satisfactory, but its basic idea is certainly seen as revealing.

\section{Social studies of science: Latour}

To some extent, this book may be considered as a product of the historiographical revolution discussed above. It is a discussion of natural history in the eighteenth century and its transformation in the beginning of the nineteenth century. In other words, it is an attempt to capture that "basic concern of the eighteenthcentury naturalist" Burkhardt is talking about, and to see how, from the end of the eighteenth century, that concern was displaced by new approaches to the study of living beings. So, a substantial part of this book is devoted to a description of historical developments in eighteenth and early nineteenth-century natural history. Moreover, in the light of this description I will also discuss Foucault's analysis of these historical developments.

However, in writing this book, my intention has not been to contribute to the historiography of natural history. First of all, this book is the result of an attempt to consider the consequences of another intellectual revolution which by now has strongly affected the study of science. Whereas for a long time the history of science has been predominantly a history of ideas, we see since the 1970 's a rapidly growing interest in social studies of science. That is, to understand how ideas are shaped, accepted, maintained or rejected, historians and sociologists of seience have shifted the attention to the interactions within scientific communities and to the broader social and cultural contexts in which scientists are working. Thus, we now have a variety of studies in which historical developments in natural history are related to the eighteenth-century fashion of collecting, to explorations and colonialism, to the emergence of distinct communities of scientific practitioners, to social and political ideologies, etc. ${ }^{8}$

One may of course doubt if this is an intellectual revolution different from that which Jacques Roger is talking about. Indeed, historians of science who abandon the idea of progress and replace continuity by discontinuity also attempt to contextualize the development of scientific knowledge. That is, they no longer see the past from the vantage point of the present, but try to understand each form of knowledge in relation to a particular time and culture. Yet there remains an important difference between Roger's historiographical revolution and the radical attempts at contextualization which characterize social studies of science. In their attempts to understand how ideas are shaped by the practical, social and cultural experiences of scientists, authors in the field of social studies of science generally tend to emphasize the variety of local, ideosyncratic prac- 
tices and beliefs which characterize the work of individual scientists. From that perspective, the conception of history as a discontinuous series of lasting and all-embracing "frames of mind" often completely disappears from view, if indeed it is not outrightly rejected. ${ }^{9}$ How to relate, for example, eighteenth-century science to the "Enilightenment spirit", when the Enlightenment is more and more dissolved by social historians into a variety of intellectual themes rooted in many different social movements? ${ }^{10}$

The difference between the two "revolutions" distinguished above clearly comes to the fore when we contrast the Foucauldian history of epistemes with the conception of science in action recently propagated by another French author, Bruno Latour. " Latour is very clear on what he wishes to avoid in the study of science. In his view, all hypotheses about major changes, be it in the mind or human consiousness, "mentalites", social relations or the economic infrastructure, are simply "too grandiose" to explain the emergence of science or its present achievements. ${ }^{12}$ However, in seeking a more modest kind of explanation, Latour also wishes to avoid what he calls a simple relativism. Relativists conceive of scientific knowledge as being like any other form of knowledge. Their position towards claims to truth or rationality is called symmetric. That is, if we accept scientific knowledge as rational, a relativist will show us that there are no reasons to deny that claim to other forms of knowledge. Latour agrees that it is "too complicated a hypothesis" to base a distinction between non-scientific and scientific knowledge on the idea of a more rational mind. ${ }^{13}$ But this relativistic stance should not, in his view, seduce us into denying the enormous effects of scientific knowledge. Scientists continually strive to make their claims more credible than those of others, to create, in other words, an asymmetry between claims. How, then, do scientists succeed in making their claims stronger than those of others?

In essence, Latour's answer is the following. ${ }^{14}$ Scientists fortify their claims by tying statements to a variety of statements, things and phenomena, and the scale upon which they make these associations differs from what we do in everyday life. That is, to account for the difference between the scientific and the non-scientific, Latour points at the number of elements linked, the strength and length of the linkages, and the obstacles which stand in the way a modification of these links. For example, eighteenth-century naturalists who were preoccupied with classification, attempted to create a network in which plants, animals and minerals could be linked into one comprehensive system. How to account for the difference between their scientific classifications and those of a savage tribe in New Guinea? According to Latour, it is not that naturalists were more logical or rational in the way they made their associations. We can only understand the difference if we follow these naturalists in their journeys all over the world, bringing together more and more plants, animals and stones in herbariums and cabinets, and combining more and more descriptions 
in the abstract formulae of a classification system. In other words, it is not the logic, but the sociologics through which plants, animals and minerals were tied together, which makes up the difference between the classifications of eighteenth-century naturalists and those of savage tribes.

As Latour points out; sociologics does not imply "materialist" explanations of the sort that refer to large scale changes in modes of production or some general economic trend. ${ }^{15}$ What he is thinking about is something far more material and mundane, that is, the various practical means which enable people to tie together statements, things and phenomena into ever longer networks. In particular he refers to means of "inscription" through which things and phenomena are transformed into signs and images on paper. As we will see, it is, according to Latour, especially through the practice of inscription that scientists are able to mobilize more and more allies in favour of their statements. For Latour then the history of science is the history of all those little innovations which have enabled scientists to transform the most diverse things and phenomena into signs and images on paper which can be referred to, displayed and combined at will. As Latour sees it, the role of the mind has been vastly exaggerated. There is no "great divide" between minds that might explain the difference between prescientific and scientific knowledge. We need not refer to "high theories" or "differences in logic" to explain the abstractions of science. We should always first look at how observers move in space and time, how the mobility, stability and combinability of inscriptions are enhanced, how the networks are extended, how all the information is tied together in a cascade of re-representation, and only then, if there is something still unaccounted for, may we look for special cognitive abilities. ${ }^{16}$

\section{A confrontation}

In the foregoing I have introduced the views of Foucault and Latour against the background of two intellectual revolutions which, while not totally unrelated, have affected the study of science in very different ways. I have also indicated that the relation between these revolutions is an uneasy one. That becomes very clear indeed when we confront the two different accounts of natural history that are suggested to us by Foucault's The Order of Things and Latour's Science in Action. Whereas Foucault seeks to understand the particular features of eighteenth-century natural history by referring to the notion of epistemes, Latour explicitly rejects any attempt to explain the features of science in terms of particular states of mind or particular kinds of logic. In his view, we simply do not need explanations in terms of major cognitive changes to understand the history of science. 
However, the contrast between a Latourian and Foucauldian account of natural history is not at all a simple one. Both Latour and Foucault have attempted, in fascinating and highly original ways, to go beyond perspectives that focus either on ideas, institutions or interests. Both, however, have done so in very different ways. Latour especially emphasizes the heterogeneity of the elements which are tied together into networks of statements, things and phenomena. In his view, we shall never appreciate this heterogeneity if we start by making distinctions between science, technology, politics, and so on. Foucault; on the other hand, considers the histories of intellectual, institutional or political events as histories of surface phenomena. To appreciate the relations between these events, we have to identify on a deeper, archaeological level the "rules" or "regimes" which have made possible the establishment of certain kinds of knowledge and practice. Foucault, then, has attempted to establish in his work an archaeology of knowledge, uncovering the regularity of discursive practices, that is, the underlying rules that govern the way in which people have been speaking and acting with respect to certain domains of experience in certain periods of history. ${ }^{17}$ Thus, in The Order of Things, Foucault has analysed the classifying activities of eighteenth-century naturalists as a particular way of speaking and acting on plants, animals and minerals, revealing in his view the rules of a particular discursive practice, that is, the earlier mentioned classical episteme.

Foucault's descriptions of discursive practices are in fact, as Latour has pointed out, highly relevant for someone with a special interest in the practice of inscription. ${ }^{18}$ Yet, the implications of Foucault's work for the history of science contrast sharply with the views advanced by Latour. This is especially true for the archaeology underlying the Order of Things. Foucault rejects, as we have seen, a history of ideas in which the historian attempts to trace a continuous accumulation of knowledge. Indeed, in his archaeology of knowledge, he especially calls attention to the phenomena of rupture, of discontinuity in the history of discursive practices. ${ }^{19}$ Thus, Foucault has emphasized the very phenomenon which Latour so emphatically denies, that is, the occurrence of great divides in the way in which people name, speak and think. When Foucault discusses, in The Order of Things, what "enables thought to operate upon the entities of our world", he is referring, not to means of inscription, but to underlying systems of thought. ${ }^{20}$ In his view, then, the pivotal characteristic of eighteenth-century natural history was the particular logic of a classification scheme, whereas for Latour it is not the logic of classification that needs to be examined, but the sociologics through which plants, animals and stones were combined on an ever larger scale.

In this book I will pursue the confrontation between these two accounts by contrasting Foucault"s discussion of natural history with a Latourian analysis, which I have elaborated on the basis of my description of historical develop- 
ments in eighteenth and early nineteenth-century natural history. In developing this Latourian account, I have started from Latour's claim that all we need to do if we want to understand the history of science is to shift our attention from the mind to means. That is, I have followed Latour's methodological rule that we should always first look at how networks are extended through the mobilization, stabilization and combination of more and more statements, things and phenomena. But, what if we confront such a Latourian account with Foucault's analysis of natural history? Must we simply and solemn bury Foucault's analysis in line with Latour's plea for a ten-year moratorium on cognitive explanations? ${ }^{21} \mathrm{Or}$, is Foucault perhaps referring to phenomena unaccounted for in a Latourian explanation? If so, in what way and to what extent can we understand Foucauldian logic in terms of a Latourian sociologics?

In my view, Foucault's analysis remains very interesting because it clearly exposes some particular cognitive features of natural history which cannot simply be ignored by a Latourian observer. However, whereas these features remain rather enigmatic within the framework of Foucault's archaeological analysis, they become much more understandable, as I hope to show, when we analyse the development of natural history from a Latourian point of view. Thus, in a first confrontation, I will show that the abstractions of naturalists, which in Foucault's analysis appear as the manifestation of a particular episteme, can very well be understood as the result of an endless chain of heterogeneous activities in which plants and animals were mobilised, stabilised and combined. But what about Foucault's major claim that natural history was transformed at the end of the eighteenth century through a sudden and radical change on the underlying, epistemic level of forms of thought? This question will be the subject of a second confrontation in which I will show how it is possible to understand discontinuities in naturalists's conceptions of the world as the result of continual attempts to extend networks of statements, things and phenomena.

\section{A history of natural history}

In the foregoing I have already indicated that a large part of this book is devoted to a history of natural history in the eighteenth and early nineteenth century. It is a history in two parts. In the first part, I describe how, in the eighteenth century, plants and animals were being collected and classified and how these activities took shape in the work of the two most illustrious naturalists of the century: Linnaeus and Buffon. This history I take as a starting-point for a first confrontation between a Latourian and Foucauldian account of what happened in this period. In the second part, I focus on the practice of zoological classification in France at the end of the eight- 
eenth century, taking up the well-known theme of the transformation of natural history. A theme which, in the history of zoology, is especially bound up with the names of Cuvier and Geoffroy whose work I discuss in detail. Then, in a second confrontation, I make this typical Foucauldian theme of a transformation of natural history into a test-case for a Latourian observer.

Thus, in this book the reader will find three stories about natural history. The first story is a history of natural history in which I describe the experiences, practices, ambitions and conceptions of naturalists as they appear in the accounts of historians of science and in the accounts of these naturalists themselves. In addition there are the stories told by Foucault and by a Latourian observer in which the reader is asked to look beyond this history for a deeper understanding of what was going on. So, in this book I use an historical account of natural history as an empirical basis which allows me to juxtapose and compare two different perspectives on the history of science. Hence, in writing this account I have attempted not to privilege any particular perspective, but to move, instead, between different points of view. My aim was not an intellectual, institutional or political history, but a history in which these various aspects would go together.

The result of my attempts is a historical account of natural history in which the reader will find descriptions of: the way in which collections of plants, animals and minerals have been created in gardens, herbaria, cabinets and museums; collective practices and perceptions that were embodied in the activities of apothecaries, physicians, cabinet naturalists, field naturalists, etc.; epistemological ideals in terms of which naturalists have been justifying their activities; as well as systems, theories and concepts, appearing in the writings of individual naturalists. Moreover, in writing this history, I have also implicitly and sometimes explicitly sought to define relations between these different aspects. In doing so, I have interpreted the classifying activities of naturalists as constituting a process of abstraction, with collections, collective practices and epistemological ideals appearing as conditions that help us to understand the shaping of abstractions like "types" and "laws" in natural history. To show in more detail how this process of abstraction was being organized in the hands and heads of naturalists, I have combined chapters with general historical descriptions with chapters focused on the work of some prominent, and indeed, very different individuals. As such these individual histories also remind us of the fact that natural history has been created and transformed in what was often a battle between very different practices and conceptions.

For these historical descriptions I have in general had recourse to available histories, dealing with different events, persons and periods in eighteenth and nineteenth-century natural history. To examine in more detail how abstractions 
took shape in the work of those four naturalists who occupy a special place in my account, I also relied on some of the best-known publications of these naturalists themselves: But even then, I must first of all acknowledge the stories of historians of science without which it would have been difficult for me to understand what these primary sources were about. Here, 1 especially want to mention one of the most helpful of these secondary sources, namely Daudin"s elaborate history of classification from Linnaeus to Cuvier and Lamarck, which is now more than fifty years old but which is still very interesting and instructive. ${ }^{22}$ In Daudin's work we find not only extensive discussions of the methods, the contents and the transformations of botanical and zoological classifications in the eighteenth century, but also many suggestive observations on the intellectual, social and technical conditions which have shaped the classifying activities of eighteenth-century naturalists. Moreover, although the names of Linnaeus, Buffon and Cuvier figure prominently in Daudin's work, it is far more than a history of great naturalists. Like many historians and sociologists of science today, Daudin approaches the history of classification as the history of a collective endeavour in which many naturalists have taken part.

I have introduced natural history as the science in which plants, animals and stones were studied, described and classified. In fact, it is not so easy to define what eighteenth-century natural history was and what it was not. Plants and animals were studied by university professors, that is, professors of medicine, but also by amateurs: clergymen, merchants, those of independent means, leisure or both. Natural history thrived on the fashion of collecting, but also on minute and sophisticated observations of the living animal or plant. There were naturalists who mainly studied plants, animals or minerals gathered in a garden or a cabinet, but there were also those who passed long hours in the field or who travelled around in distant countries. In my account of natural history I have not attempted to write a comprehensive history of all those various activities. What follows is a story focused on problems of classification, problems which, as we will see, preoccupied many a naturalist in those days. 


\section{References}

1. Roger, 1980.

2. Foucault, 1970 a.

3. To mention a few examples: Coleman, 1977, chapter 1; Hoppe, 1978; Roger, 1980; Lyon and Sloan, 1981, Introduction. See also Lepenies, 1976, who discusses the theme of "the end of natural history" in a general, but rather elusive way. For a different account of what happened to natural history at the end of the eighteenth century see Farber, 1982 a. For a critical review of the extensive literature on a (new) "biology" see Caron, 1988.

4. Albury and Oldroyd, 1977.

5. Albury, 1977 .

6. I have already mentioned the names of Albuly and Oldroyd. Other authors who to a certain extent have followed Foucault's approach are: Jacob, 1973, Figlio, 1976; and Cross, 1981.

7. Burkhardt, $1977, \mathrm{p} .46$.

8. For a review of a number of these studies, see Secord, 1985. More recent examples are Appel, 1987; and Corsi, 1988.

9. Thus, Secord warns that such frames of mind easily "can take on a life of their own, independent of any social context or even any individual scientist". Ibid., p. 187.

10. See for an interesting discussion of this point: Golinski, 1986. See also Jordanova, 1982.

11. Latour, 1987.

12. Latour, $1986, \mathrm{p} .1$.

13. Ibid., p. 2.

14. Latour, 1987 , especially part III.

15. Latour, $1986, \mathrm{pp} .3-7$.

16. This is one of Latour"s so-called rules of method. See Latour, 1987, p. 258.

17. This attempt at an archaeology of knowledge is principally to be found in Foucault's èarly work. See for a general discussion Foucault, 1977.

18. In this context Latour in particular refers to the analysis in Foucault's Discipline and Punish. See Latour, 1986, p. 15.

19. See for this point especially the introduction in Foucault's The Archaeology of Knowledge.

20. See the preface in The Order of Things.

21. Latour, 1987, p. 247.

22. Daudin, $1926 \mathrm{a}$ and $1926 \mathrm{~b}$. 
PART I 
8 
CHAPTER I

\section{NATURAL HISTORY}

\section{A participant's view}

To see what natural history was in the eighteenth century in the eyes of its practitioners we may consult the article on Natural History in the French Encyclopédie of Diderot and d'Alembert, published in $1765^{1}$. The spokesman behind this article was Louis Daubenton, a well-known Parisian naturalist of whom we will hear more later. In his article it is stated that the object of natural history equals nature in its comprehensiveness:

il comprend tous les êtres qui vivent sur la terre, qui s'élevent dans l'air, ou qui restent dans la sein des eaux, tous les êtres qui couvrent la surface de la terre, \& tous ceux qui sont cachés dans ses entrailles.

Animals, plants and minerals constitute, according to the article, the three main divisions of natural history. The first knowledge of these objects was obviously acquired through agriculture and the domestication of animals. In the course of time, however, these activities gave rise to more systematic investigations leading to the birth of sciences like anatomy, medicine and botany, sciences which proceed from natural history like the branches of a tree from its trunk. How then, the author of the article wonders, does natural history give this scientific tree its strength?

The basis of natural history is the description of the productions of nature as the only means to get true knowledge of each form in particular. Equally important and preliminary to any science is a vocabulary which allows for the naming and description of objects in terms which are understood by every author. The naturalist, however, does not confine himself to description per se. On the contrary:

Le naturaliste ne considère une chose que pour la comparer aux autres; il observe par préférence dans chaque chose les caracteres qui la distinguent des autres, \& il fait tous ses efforts pour voir la marche de la nature dans ses productions. 
The article then compares the activities of the naturalist to those of the anatomist and the chemist. A comparison which perhaps owes its significance to the fact that at those times there were in the main centre of natural history in France, the Jardin du Roy in Paris, chairs for botany, anatomy and chemistry ${ }^{2}$. Whereas, according to the article, the anatomist studies every object by itself, it is the naturalist who compares and who, in contrast to the chemist, studies his objects as much as he can in their natural quality:

Le naturaliste recherche toutes les productions de la nature dans son propre sein; il leve avec précaution le voile quil les couvre; il les observe d'un oeil attentif sans oser y porter une main téméraire, s'il est obligé de les toucher, il est toujours dans la crainte de les déformer; s'il est forcé de pénétrer dans l'intérieur d'un corps, il ne le divise qu'à regret, il n'en rompt l'union que pour en mieux connoître les liens, \& pour avoir une idee complette de la structure intérieure aussi bien que de la forme extérieure.

If it is the task of the naturalist to describe and compare every animal, plant and mineral, how can he achieve this? The number of natural productions is immense and no one is able to go and search everywhere. Progress in natural history clearly is and cannot be the work of a single genius. Even all the inhabitants of a nation will not suffice. What is needed is the collective effort of many nations during a series of centuries. The author of the article thus rejoices at the popularity that natural history has gained in the eighteenth century. A popularity which has taken shape not only in a zeal to observe, but also to collect. The result is a growing number of naturall history cabinets and the article emphasizes the great value of this development for the progress of natural history. Now, more than ever, the naturalist can study the dispersed productions of nature within the walls of a cabinet:

...on a trouvé le moyen de racourcir \& d'applanir la surface de la terre en faveur des naturalistes; on a rassemble des individus de chaque espece d'animaux \& de plantes, \& des échantillons des minéraux dans les cabinets d'Histoire naturelle. On y voit des productions de tous les pays du monde, \& pour ainsi dire un abregé de la nature entiere.

So, natural history progresses as the cabinets fill up, although the author warns that the cabinets can never replace the study of the "living" and "active" nature ${ }^{3}$.

The article also contains some more critical remarks regarding current practice in natural history. First of all, it is observed that descriptions in natural history often are incomplete, that is, descriptions are made with the sole inten- 
tion at distinguishing an object from other objects and so are limited to a few distinctive characters taken only from a single part. What makes matters even worse is that on the basis of these incomplete descriptions objects are named and arranged into systems which are erroneously held to be the reflection of a natural order. Such a methodical arrangement may be reasonable as a means to relieve the task of memorizing the multiplicity of forms, but one may never forget that the resulting systems are only arbitrary conventions which do not correspond to the invariable laws of nature. The relations between the productions of nature are too numerous and subtle to be captured in a system based on a few distinctive characters. Thus we need complete descriptions relating all the parts of objects. Only then, on the basis of many of such descriptions, may we hope that a true, natural system can ever be achieved. Especially in botany, so the article continues, have naturalists overemphasized nomenclature at the cost of the study of the qualities of plants, based on the cooperation of all parts, that is, on the "vegetal economy". How many new properties of plants could have been discovered if botanists had spent their time in studying them instead of naming them! And how much more useful could their knowledge have been for the advancement of agriculture!

\section{Gardens, herbaria, menageries and cabinets}

The article in the Encyclopédie gives us an interesting picture of how work in eighteenth-century natural history was organized or how, in the view of the author, it ought to have been organized. Natural history was not only an endeavour of lonely naturalists wandering in the field at home or abroad, but was shaped, as the article clearly indicates, by institutions of various sort. In his book The Naturalist in Britain, David Allen has described how the organization of botany initially took shape in relation to professional interests, such as those of the Society of Apothecaries in London. ${ }^{4}$ This society maintained a botanic garden and organized special herbarizings in the field for instruction of the apprentices who had to learn how to recognize useful drug plants. The first records of these activities are from 1620. Later on in this century the organization of herbarizings and the instruction in the garden was entrusted to a special paid official, the demonstrator of plants.

In the course of time the activities of the Society inspired other forms of organization, as for example a botanical society, founded in 1721 , which held weekly meetings during which "every member in turn had to exhibit a specified number of plants, give their names and make observations on their uses" ${ }^{5}$. The twenty-three or so members of the society were mainly students almost all des- 
tined to become apothecaries, physicians or surgeons. Other branches of natural history also began to organize in the eighteenth century. Allen mentions the entomological Society of Aurelians of which it is unknown how it commenced, but which was probably founded by Joseph Daundridge who was an avid collector, not only of insects, but of shells, fossils, birds' eggs, bird skins and plants as well.

We have seen that making these collections was another conspicuous aspect of organization in eighteenth-century natural history. Towards the end of the seventeenth century, Allen observes, "a cabinet of natural (and artificial) curiosities had come to be regarded as one of the essential furnishings of every member of the leisured classes with claims to be considered cultivated". 6 In the eighteenth century the zeal to collect thus became a widespread fashion, whereby natural history objects often formed but a subsection of a larger general collection of "objects d'art", antiquities, and books. ${ }^{7}$ Sometimes these collections grew out to enormous proportions, as for example that of Lady Margaret Cavendish Bentinck, the wife of the second Duke of Portland. She managed to create a collection which was the largest in eighteenth-century Britain. In addition to her collection, contained in a private museum, she also kept a botanic garden and a considerable menagerie. She employed several naturalists for collecting, arranging and cataloguing, as well as artists for making illustrations. The sale of her collection by auction after her death required thirty-eight days!

In Britain, Emanuel Mendes Da Costa was another notable example. He owned a large collection of shells, minerals and fossils and, according to Allen, "had built up by the middle of the century ... a wide network of correspondents scattered around the country whom he regularly succeeded in persuading to explore their local quarries and to send him some at least of the spoils from these that resulted". ${ }^{8}$ Collections, however, were not the only way in which natural history materialized in the eighteenth century. Illustrated books became another popular form in which nature could be displayed and admired. So there appeared, often in series of volumes and in many editions, books like The Natural History of English Insects, The History of Birds, and many others.

What Allen describes for Britain, we find in other countries too. Botany, especially flourished in Holland, with botanical gardens in Amsterdam and Leiden which were in the beginning of the eighteenth century unsurpassed in the extent and quality of their collections. ${ }^{9}$ As such these gardens reflected another aspect of the growth of natural history. Exploration and colonial expansion had become an important source of "exotic" specimens which were grown in gardens and kept in herbaria. Thus, Stafleu writes, "the Amsterdam and Leiden gardens were centres for the receipt of new plants introduced mainly from the Cape of Good Hope but also from the Canary Islands, the West Indies 
and even, although in modest numbers, from Ceylon and the Indian peninsula. Dutch colonial and trade expansion was at its peak and Dutch ships sailed all over the world. The rising affluence of the Dutch Golden Age, the seventeenth and the early eighteenth century, had created a group of wealthy merchants and bankers who became interested in promoting science and in growing exotic plants themselves". ${ }^{10}$

In France there was the Jardin royale des herbes médicinales or simply Jardin du Roy, founded in Paris in 1635. From 1683 to 1708 the illustrious French botanist Joseph Pitton de Tournefort had taught there. ${ }^{11}$ In Versailles, under the French king Louis XIV, there was also established a menagerie, which not only created opportunities for direct observation of animals from distant climes, but also for dissection of their bodies. ${ }^{12}$ And, as the article in the Encyclopédie amply demonstrates, in France too, collecting became important in the eighteenth century. Farber quotes for example the comments of the eighteenth-century naturalist Pallas, who observed in 1763 on the Parisian collections:

Collecting natural Curiosities is now in vogue to that degree that no body is thought du bon ton, who has no collection. The decorations of some Cabinets are more expensive than the Curiosities themselves, and taste so much of that gout manque (or outré) ... that the Collections seem more like Raryshows, than anything of a Scientific nature. ${ }^{13}$

Especially famous was the cabinet of Rene-Antoine Ferchault de Reaumur, the "Prince of Naturalists" and member of the Académie Royale des sciences. ${ }^{14}$ Réaumur succeeded in solving some of the problems in preserving bird specimens, problems which were responsible for the generally small number of quadrupeds and birds represented in the cabinets of the day. Thanks to his preservation method and with help of his extensive network of correspondents throughout Europe and the colonies, Réaumur assembled the largest bird collection then extant in Europe. A collection which, after Réaumur's death in 1757, was transferred to the large natural history collection of the Cabinet du Roy which was connected to the Jardin du Roy.

\section{Problems of order}

The growth of natural history in terms of the number of specimens assembled from distant places, grown in gardens, collected in herbaria and in cabinets, created problems of order which were not new as such, but which acquired new 
dimensions. The naturalist who was in charge of a garden, herbarium or cabinet hardly could escape difficult questions of organization. How to arrange the growing number of objects in his collection: according to nature, to taste, to educational or scientific purposes, or what? So, it is not surprising to find in the Encyclopédie an article on the Natural History Cabinet, dominated by the question of order. ${ }^{15}$ The author (again it was Daubenton) comments with disgust on those naturalists who show their collections in a state of disorder and then exclaims:

Renvoyez toutes vos coquillies à la mer; rendez à la terre ses plantes \& son engrais, \& nettoyez vos appartemens de cette foule de cadavres, d'oiseaux, de poissons, \& d'insectes, si vous n'en pouvez faire qu'un chaos où j'apperçois rien de distinct, qu'un amas où les objets épars ou entassés ne me donnent aucune idée nette \& précise.

But which order must reign in a cabinet? It must be first of all instructive and so it cannot be the "sublime disorder" of nature. The article then approvingly quotes none other than Daubenton himself, in his function of "garde et démonstrateur" of the Cabinet du Roy, saying that the arrangement must be methodi$\mathrm{cal}$, that is, according to classes, genera and species, with animals, plants and minerals placed in different quarters. Such an arrangement will facilitate the study of natural history because it shows every object individually and in comparison with others:

Les ressemblances indiquent le genre, les différences marquent l'espece; ces caracteres plus ou moins ressemblans, plus ou moins différens, \& tous comparés ensemble, présentent à l'esprit \& gravent dans la mémoire l'image de la nature. En la suivant ainsi dans les variétés de ses productions, on passe insensiblement d'un regne à un autre; les dégradations nous préparent peu à peu à ce grand changement, qui n'est sensible dlans son entier que par la comparation des deux extrèmes.

However, from the rest of the quotation, it becomes clear that Daubenton considers such an arrangement neither natural nor wholly practicable. It is an illusion to think that we know the things through knowledge of their arrangement and sometimes it is more gratifying and instructive to show the objects in a less methodical manner.

The problems of order, however, had a much more far-reaching dimension yet. Naturalists in different countries and working with different collections often used different names and different systems in their attempts to arrange the increasing number of known species. Moreover, in the eighteenth century the 
number of systems tended to increase as the number of collections grew. Allen even suggests that "hardly any two persons observed the same system of classification 16 This situation not only raised practical problems of communication, but also raised the burning question of what would be a true or "natural" system of classification. Such problems of classification were indeed not new. Especially in botany naturalists had been occupied with them ever since the sixteenth century when the compilations of known plants steadily began to grow in size. So in the attempts of eighteenth-century naturalists to create order in the three "kingdoms" of nature, existing practices in botanical classification often served as a model. ${ }^{17}$ Before discussing the work of Linnaeus and Buffon in the next chapter, I will therefore briefly trace the history of these practices in botany as well as their significance for the attempts at classification in zoology.

\section{Problems of botanical classification}

Early attempts to establish groupings of plants can be found in the sixteenth century in the herbals of the so-called herbalists. ${ }^{18}$ These herbals were mainly compilations of descriptions of individual plants, but often the author juxtaposed the descriptions of those plants which in one way or another resembled each other. At first, these groupings were only intuited on the basis of general outward appearance. At the end of the sixteenth century, however, the herbals contained more deliberate attempts to arrange plant forms on the basis of an analysis of external resemblances and differences. As a result many smaller and more comprehensive groups of plants were established as natural "genera" and "families". Two circumstances promoted these early attempts at systematization, first, the description of a growing number of plants which evidently had not been known to the Ancients and second, the need of correct identification of these plants in view of their medicinal virtues. This need to manage a growing number of plant descriptions in such a way that any given plant could be readily identified, also explains, according to Daudin, the subsequent search for a "system" or a "method" of classification. This search characterized botany from the sixteenth century onwards, even to such an extent that naturalists came to see it as the very soul of the science. ${ }^{19}$

How to identify any given plant with ease and certainty? Information on the locality or use of plants, important as it clearly was, was seen by most naturalists as unsuited to identification purposes. To enable a plant to be identified without any prior knowledge, emphasis was laid on the use of external characteristics, especially those which were stable, easily seen and which could be distinguished on any plant. However, invocation of these characteristics all at once would suppose a capacity to 
recognize the correct species at a single glance. It would have been evidently insufficient, as Daudin observes, to have designated extemal characteristics, without explaining how to invoke them step by step, according to a system of classification. ${ }^{20}$ In such a system various external characteristics were used, one after the other, for successive divisions of the known plants into groups like, for example, plants with or without flowers, etc. But, which characteristics were considered useful in such a procedure and, more importantly, in which order? During the sixteenth and seventeenth century many classifications were created, based upon various aspects and combinations of roots, stems, leaves, fruits and flowers, whereby naturalists often chose those characteristics which seemed to be most convenient in practice. However, there were also naturalists who sought to base their choice of characteristics on more theoretical considerations.

An early example is the work of the Italian professor in medicine and botany Andrea Cesalpino in the latter half of the sixteenth century. According to Sloan, Cesalpino's concern, "unlike that of the herbalists, was in founding a science in the Aristotelian sense, an enterprise based not on utilitarian or medicinal concerns, but one founded on the search for knowledge of the essential structure of nature itself". ${ }^{21}$ In Cesalpino's words the study of plants had to be a science based on:

the collection of similar [things], and the distinction of dissimilars, and the distribution of these into genera and species like armies [classes], according to the differences indicated in the nature of things. ${ }^{22}$

As Sloan makes clear, this definition was composed of two elements. Classification had to be based on the traditional Scholastic method of logical division of groups into genera and species. A method, indeed, which concurred with systems of classification already used in practice whereby characteristics were utilized one after the other for successive divisions. However, when using logical division, the choice of characteristics on which divisions into genera and species were to be based was not at all arbitrary. These characteristics had to define the "nature" or the "essence" of things. Thus, for a scientific classification, a further element was deemed necessary in addition to a method, that is, a theoretical foundation permitting "genuine demonstrative knowledge of essences" ${ }^{23}$ Only this knowledge of essences would yield a correct choice of a "fundamentum divisionis" containing the characteristics on which natural divisions into genera and species could be based.

In accordance with Aristotelian theory, Cesalpino considered two functions as essential in plants, that is, nutrition and reproduction. Thus, he based the primary division in his botanical classification on the nutritive parts - the hard- 
ness of the root and the stem - and all subordinate divisions on the reproductive parts - the number, location, shape and structure of parts in the fruit and fructification. The choice of these latter parts also rested on practical considerations, as becomes clear from Cesalpino's argument that:

There is reason to establish many genera of plants on the production and structure of fruits, since nature employs for the production of no other part of the plant so great a number of different parts. ${ }^{24}$

The primary division of plants, then, differentiated "woody plants" and "herbaceous plants". In his first subdivisions Cesalpino divided his "trees" into plants with "one-seeded fruit cells" and plants with "several seeds in each cell", while the "herbea" were divided into four groups according to "the number of seeds produced by the flower or contained in a receptacle of some kind". ${ }^{25}$

Cesalpino's work proved to be very influentiall. In the course of the seventeenth century the selection of reproductive parts as the "fundamentum divisionis" for subordinate divisions of groups of plants was accepted by many. Yet, the victory was not complete. Cesalpino considered his classification "natural" precisely because his divisions were according to the nature or essences of things. But not every naturalist in the seventeenth century accepted this claim. John Ray, working in England in the second half of the seventeenth century, published botanical classifications in which he based his divisions not only on the parts of reproduction, but on other parts of the plant as well ${ }^{26}$ For example, he divided the "herbae", not on the basis of the number of seeds, but on the basis of the number of seed leaves surrounding the embryonic plant. Moreover, in his subsequent subdivisions he occasionally used characteristics like the location of leaves on the stem, or the shape and the odour of the root.

Like his contemporaries Ray accepted the necessity of a system, since the number and variety of plants, in his words:

inevitably produce a sense of confusion in the mind of the student, but nothing is more helpful to clear understanding, prompt recognition and sound memory than a well-ordered arrangement into classes, primary and subordinate. ${ }^{27}$

According to Ray, however, a system had to preserve apparently natural groups, that is, groups established on the basis of the general outward appearance of plants. So, he criticized the work of his German contemporary Rivinus for too strictly adhering to Cesalpino's principles, because it led to the splitting or lumping of groups which had been accepted as natural by most of the herbalists and horticulturists. ${ }^{28}$ Nature, Ray observed, resists being locked up in a system, be- 
cause there will always be anomalous species to which the criteria of system cannot be applied without ambiguity. Ray neither wished to contest the authority of Cesalpino, nor deny that a system based exclusively on parts of the fructification would be acceptable if splitting or lumping of natural groups could be avoided. In his view, however, such a perfect system was as yet impossible. Thus, other characteristics had to be invoked as a means to preserve natural groups.

Reactions to Ray's point of view came not only from Rivinus, but also from Tournefort, the famous demonstrator of plants at the Jardin du Roy in France. According to Tournefort:

To know plants is precisely to know the names one has given to them in relation to the structure of some of their parts. This structure makes the character which essentially distinguishes plants from one another. ${ }^{29}$

Since Tournefort considered the flower and the fruit as the only parts which were essential and also permitted a satisfactory classification, his system of classification was based on the presence or absence of flowers, on petaled or apetalous flowers, on simple and composite flowers, on the number of cells in fruits, etc. Thus, in the eyes of Tournefort, Ray's system found no favour on the argument that his designation of genera was by characters based on convenience rather than botanical insight. ${ }^{30}$

\section{A battle of systems}

From the foregoing we may conclude that in botany at the end of the seventeenth century the need for a system of classification was generally accepted. But at the same time the use of these systems was evidently a controversial matter. A controversy which continued well into the eighteenth century as is clearly indicated by the article in the Encyclopédie with which this chapter opened. What was involved in this battle of systems?

First, there was the question of the status of a system; was it merely a convenient method for memorizing plants, or had a system somehow to represent the order in nature? Opinions on this point varied. For example, Boerhaave, professor of medicine and botany at Leiden in the early eighteenth century, wrote in 1719:

The End and Design of Method is to help the Memory, and to range every thing distinctly in its proper Place. That System therefore is ever the best which is most easy; I do not say which is most natural, for we do not know what that is: But if you examine all Systems whatsoever, you will very easily find that of Tournefort to be preferable to all the rest. ${ }^{31}$ 
As we have seen, Tournefort himself wished to respect in his system the real relations which are found among the genera of plants, that is,

the relations drawn from the structure of their essential parts, which are the flower and the fruit. ${ }^{32}$

But, at the same time, Tournefort admitted that he preferred the flower as the basis of his classification because for his students in Paris it was most convenient to recognize, even when such a system sometimes led to unnatural results. ${ }^{33}$ Ray, on the other hand, evidently preferred to sacrifice the rigour of a system in order to preserve what he saw as natural groups, thus, searching for a method "as perfect as nature permits". ${ }^{34}$

Moreover, the case of Ray also demonstrates that naturalists who agreed in their claim that a system somehow had to represent nature, could wholly disagree on the justification of such a claim. On the one hand, there were naturalists like Rivinus and Tournefort who followed the principles of Cesalpino, according to which a system was natural as far as it revealed the essence of things. Divisions, then, had to be based on an essential part of the plant. Ray, on the other hand, freely used a variety of characteristics for his divisions just to prevent the splitting or lumping of apparently natural groups. In a reaction to the critical remarks of Tournefort he even went so far as to deny that we could know the essence of things and then concluded:

Therefore, since the essences of things are unknown to us, certainly the essential generic characters could not be known to us. However, it is probable that those plants which agree in several attributes, conform in their natures. Therefore, it cannot be properly saild that the flower or fruit in plants are essential parts. ${ }^{35}$

Thus, in his later work, Ray began to justify the use of a variety of characteristics in his classifications on the basis of a philosophical argument, implying a further departure from the accepted theoretical basis of systematic botany, probably, as Sloan suggests, under the influence of Locke's critique on classification in his famous Essay of $16900^{36}$

The variety of botanical classifications, however, not only revealed various practices and justifications, it also indicated a tension which was evident in the classifying activities of almost all naturalists. On the one hand, a system was perceived as something necessary, given the enormous and growing multiplicity of plants, whereby, as Larson observes, "the practical need for easy identification, especially at the higher systematic levels, led to a stress on parts which of- 
fered a fundamental principle in some complex structure of fairly constant characters", and "often coupled with speculation about "essential" or "perfect" parts, this practical necessity led directly to characterization by means of single parts...". ${ }^{37}$ On the other hand, naturalists often tended to accept as "natural" those groups of plants which showed multiple affinities in their general outward appearance. Even Cesalpino, in working out his classification practically, seems to have started from groups constituted on the basis of their general outward appearance which he then attempted to rationalize according to the criteria of his system. $^{38}$

Moreover, many naturalists agreed upon a conception of nature according to which the multiplicity of forms were related to each other in a continuous chain. A conception, indeed, with a long history, but one which often reverberated in the writings of seventeenth and eighteenth-century naturalists. So, Ray was no exception when he wrote:

Nature, as the saying goes, makes no jumps, and passes from extreme to extreme only through a mean. She always produces species intermediate between higher and lower types, species of doubtful classification linking one type with another and having something in common with both - as for example the so-called zoophytes between plants and animals. ${ }^{39}$

Indeed, a tension between conceptions of system and conceptions of nature was clearly felt and continued to be felt in the eighteenth century, when problems of order acquired new dimensions in botany as well as in zoology.

\section{Problems of zoological classification}

Daudin gives an interesting account of the historical circumstances in which classifications in zoology have taken shape. ${ }^{40}$ Historically, these circumstances have been different from those in botany. However, when, much later than in botany, a need for detailed zoological classifications began to arise, zoologists were faced with problems which were to a considerable extent the same as those in botany.

A circumstance which has traditionally favoured classification in botany has been the easy accessibility of plants compared to that of animals. The botanist could study plants by close inspection in the field, but he could also grow them in a garden or keep them in an herbarium in which their characteristics could be studied and compared again and again. Due to their locomotion, however, non-domesticated animals generally refused detailed study in the field and 
poor techniques of preservation limited the possibilities for study and comparison at home. Moreover, the medicinal concerns which demanded the exact determination of plants and so stimulated classification were missing in zoology. As a consequence, classification in zoology relied, until the eighteenth century, far more than in botany on conceptions adopted from ancient traditions. Thus, the ancient division of animals into a number of comprehensive classes, like Quadrupeds (oviparous or viviparous), Birds, Snakes, Fishes, etc. was taken for granted by naturalists well into the eighteenth century.

But the situation in zoology differed from that in botany in another respect as well. In botany, naturalists had traditionally been satisfied with a description of the external characteristics of their objects as the basis for a classification. There was no need to refer to the internal organization of plants and, from what naturalists knew of it, there was also no reason to believe that it would be very distinctive. In zoology, on the other hand, knowledge of the anatomy of animals was a source of important distinctions some of which were already manifest in ancient classifications. Common observations on slaughtered animals as well as more systematic anatomical investigations related to medical interests suggested some striking resemblances and differences in the internal organization of animals, for example with regard to the arterial system. Such observations further suggested some general criteria according to which animals could be classified. Thus, in his zoological classification Ray distinguished animals with and without blood (as did Aristotle), where he subdivided the first group into animals with pulmonary respiration and animals with bronchial respiration (fishes). The animals with pulmonary respiration were further divided according to the number of ventricles of the heart (like snakes with only one, and terrestrial quadrupeds with two); etc.

We have seen that from the end of the seventeenth century botanical and zoological collections increased in number and in scale and it was precisely this circumstance which created in zoology, as it did in botany much earlier, the need as well as the possibility for more exact determinations of the multiplicity of forms in view of their methodical arrangement. Most important in this development were the cabinets, confronting naturalists with problems of organization like those which were so extensively discussed in the article on the Natural History Cabinet in the Encyclopédie. As Daudin points out, the intentions of those naturalists who faced these problems of organization often extended beyond the walls of a cabinet. What they aimed at was more than just a convenient arrangement of this or that collection; it had to be an arrangement according to general principles applicable to the animal world as a whole. The work of Jacques Brisson, "garde et démonstrateur" of the earlier mentioned cabinet of Réaumur, is a conspicuous example of this search for system inspired by, what Farber calls, "a 
museum curator's perspective". ${ }^{41}$ In 1756 Brisson published a Règne Animal divisé en IX classes and he introduced this work with the following observations:

The position that I have had the good fortune to occupy for several years, which has put me in daily contact with the richest collection of nature's objects that has ever been made, has allowed me to make a great number of observations on the animal kingdom; to compare them and to examine the closest and most distant relations. I have been led to think of arranging the animal kingdom into an order different from those used up to the present time. My intention in this labour was solely to instruct myself and to place myself in the position of being able to judge the most convenient place to put a speeimen of a new animal which would arrive to be placed in a cabinet. ${ }^{42}$

Authors like Daudin and Farber show how in the eighteenth century the practice of zoological classification was indeed ruled by naturalists working in a cabinet, and they also point out how this circumstance was variously reflected in the practices of these naturalists. Daudin observes, for example, that collections of invertebrates often contained only those parts of the animals which could be easily preserved, such as shells, tests of sea-urchins, fossils, etc. As a consequence, the salient characteristics of those external parts often were used for making classifications without regard to the animals which originally were contained in them. ${ }^{43}$ But in the case of vertebrate animals too, one often had to work with skins or mounted specimens, like Brisson when he classified the birds in Réaumur's cabinet. So, it is indeed hardly surprising, that in his descriptions of birds there was no discussion of the internal anatomy and that his system of classification was based on well-preserved characteristics such as beaks and claws. ${ }^{44}$ The German naturalist Klein even justified the employment of external, easily visible characteristics in zoological classifications explicitly on the grounds that any other means of classification would imply internal inspection and, thus, destruction of any object which one wished to place correctly in a cabinet. ${ }^{45}$

\section{The continuity of being}

It is evident that the growth of collections in the eighteenth century has conditioned the rise of systems in zoology to a large extent. As these collections grew, each of the traditionally accepted comprehensive zoological classes, like "birds" or "insects", were subjected to a system of rigorous divisions which enabled naturalists to identify and arrange a growing number of genera and species. However, as in botany, naturalists at the same time often adopted an all-embracing conception of 
continuity in nature: a conception in which all forms were related in a continuous chain of being, connecting man as the most perfect animal to the most simple animal forms and then further to plants and minerals. ${ }^{46}$ In an abstract form, this idea of continuity had acquired new force at the end of the seventeenth century in the philosophy of Leibnitz, and from this source some naturalists took their inspiration to reflect on it. But more important, according to Daudin, was that the idea of continuity was also deeply rooted in the practice of zoological research. ${ }^{47}$ In zoology, man traditionally served as a model in the understanding of other animals. Man, that is, was perceived as a most perfect form to which all other forms could be compared and to which all other forms approached in different degrees.

Examples of this practice in zoology abounded in the language used for describing bodily parts, in the organization of anatomical investigations and in the plan of animal classifications. So, even though naturalists in the seventeenth and eighteenth centuries may have doubted the theoretical legitimacy of attributing "jaws", "lips" and "haunches" to insects, they choose to do so in practice. And in his work on the classification of animals, Brisson explicitly stated that he had arranged his nine classes according to the distance which separates the animals in each class from man. As the basis for the determination of this distance he used a number of analogies with man, like the presence of blood, pulmonary respiration, two ventricles in the heart, etc. So, the Quadrupeds, having all these characteristics, came first, and last came those classes which had none.

As the example of Brisson"s classification demonstrates, the adoption of a system for the classification of animals did not have to be perceived as inconsistent with the idea of continuity. In the words of Daudin, the idea of a hierarchical and continuous chain continued throughout the eighteenth century to be a "form of rationality" ready to be used as a means for understanding the multiplicity of forms. ${ }^{48}$ However, as naturalists began to pay more and more atten= tion to the identification and arrangement of animal genera and species, they came to conceive of much more versatile relations between different forms than had ever been the case on the level of the more comprehensive classes. The work of the Italian naturalist Donati is mentioned by Daudin as an early and interesting example. ${ }^{49}$ Donati studied the local flora and fauna of a marine envi* ronment and suggested a "network" as the most proper image for the understanding of the relations between the multiplicity of forms. Resemblances between these forms were so numerous in Donati's view, that he, in contrast to Brisson, saw no room for systems of classification based on only a few characteristics. So, again, we may say, a tension was felt between conceptions of system and conceptions of nature. 


\section{Natural history reconsidered}

In the beginning of this chapter I introduced the content of natural history on the basis of a participant's view, as laid down in the Encyclopedie. There, it was said that the first task in natural history is the complete description of every form in comparison to other forms, and we have seen how the author of the article lamented the emphasis on nomenclature and systems, particularly in botany. In the subsequent description of the circumstances in which natural history took shape, I have attempted to make clear that in the perception of many a naturalist problems of order were indeed most critical, although in botany much earlier than in zoology.

But we must not forget, of course, that those naturalists who in the seventeenth or eighteenth century sought to create order, acted in a world that already had been put in order to some degree, and not only in the books of a learned tradition going back to Aristotle; but also by those involved in more mundane activities like horticulture or the search for drugs. Thus, Ray, when he criticized the methodical classifications of his contemporaries, could refer to groups of plants that since long had been accepted by herbalists and horticulturists. Moreover, Ray was not alone in accepting long established distinctions between apparently natural groups of plants or animals. We have seen that naturalists in the eighteenth century generally took for granted the traditional division of animals into groups like Quadrupeds, Birds and Fishes. Another time-honoured conception of order, the ancient idea of a chain of being, was likewise generally approved.

These persistent conceptions of natural groups and a chain of being might be regarded as "pre-ideas" that were more or less strongly entrenched in specific collective practices, in particular those of herbalists, apothecaries and physicians, and which as such surfaced again and again in the activities of seventeenth and eighteenth-century naturalists. ${ }^{50}$ Thus we have seen that the idea of a chain of being was deeply rooted in the practice of zoological research, notably medical anatomy, although the idea certainly had other roots as well.

It is striking that, given the socially entrenched nature of these pre-ideas, those groups of plants and animals which naturalists deemed natural on the basis of general outward appearance, are characterized by authors like Daudin and Larson as "spontaneous" or "intuitive" constructions. Evidently such characterizations fall short insofar as they deny the collective nature of such constructions. They seem, however, to refer to something else. Groups of plants or animals that were generally accepted as self-evident might indeed be intuitive constructions in the sense that they were rooted in ordinary experience without being circumscribed in unambiguous terms. In fact, we may say that making such circumscriptions was exactly what naturalists in the seventeenth or eight- 
eenth century intended to do. Proceeding more often than not from "intuitively" constructed groups of plants or animals, they then attempted to reconstruct these intuitions in a systematic way.

What was the nature of this reconstructive activity? We thave seen how naturalists abstracted from a plant or animal specific characteristics on the basis of which groups - "classes" or "genera" - could be systematically defined. Of course, classifying objects - plants, animals, or whatever - always involves the abstraction of some resemblances or differences. But there is an important difference between the abstraction that was part of the reconstructive activity of naturalists and the abstractions of everyday life. The abstractions of naturalists were rigorous and systematic, they were executed step by step, they resulted in unambiguous definitions of classes or genera. Such abstractions allowed them to arrange and identify any given plant or animal with ease and certainty, and that was more than one could dream of in everyday life!

\section{How to explain abstractions?}

The notion of abstraction leads us to the heart of the matter when it comes to a confrontation between a Latourian and Foucauldian account of natural history, because Latour and Foucault seek to explain abstractions in different ways. Although the notion of abstraction might easily suggest a purely intellectual endeavour, Latour would emphasize that it is much more than that. That is, from a Latourian point of view the process of systematic abstraction in which naturalists were involved was made up of various activities: plants and animals were observed and collected in the field, they were transported from distant countries, they were grown in gardens or locked up in a menagerie, they were dried, preserved, sticked, mounted and arranged in a herbarium or cabinet, they were painted and described and ultimately they appeared in the definitions of a classification scheme. From this Latourian perspective, we should focus our analysis not on the abstractions of naturalists per se, but on the way in which, in the seventeenth and eighteenth century, gardens and cabinets became centers in a rapidly growing network of abstracting activities which prompted naturalists to a search for systems that might contain all plants and animals in forms that were easy to grasp.

On the other hand, from Foucault"s point of view, a focus on the growing network of abstracting activities would go only a little way towards understanding the ultimate abstractions which proceeded from these activities. That is, naturalists in the eighteenth century had particular ideas concerning the order of things. Some of them may have been satisfied with any convenient system of 
abstractions that could help to put the world in order, but others evidently had higher ambitions. They aimed at making science. In their view, the formulae of a system somehow had to represent the real order of nature. Thus, they tended to dissociate themselves from practices and circumstances related to ordinary, occupational interests or to the fashions of everyday life. Cesalpino, as we have seen, aimed at a science that would not be based on utilitarian or medicinal concerns, but was founded on the search for knowledge of the essential structure of nature itself. In the seventeenth and eighteenth century, naturalists who shared these ambitions could clearly benefit from the growing zeal for collecting which offered more and more opportunities to study nature's various productions in a natural history cabinet. But many a naturalist regretted the way in which the owners of such cabinets accommodated their collections to the public taste. Hence, the comments of Pallas quoted earlier, who considered some of the Parisian collections "Rary-shows", rather than "anything of a Scientific nature".

We have seen that Foucault attempts to understand the underlying rules according to which abstractions have taken shape in the history of science. From his perspective, we might ask what exactly naturalists had in mind when they sought to demarcate their own abstracting activities as a scientific enterprise. Undoubtedly, it was true knowledge of the natural order. And for those naturalists who attempted to achieve that goal this obviously implied the need for a theoretical foundation of the process of abstraction. Thus it was that Cesalpino attempted to define "essential" characteristics, an approach which more than a century later was also adopted by Rivinus and Tournefort: This theoretical approach, it is true, led to widely divergent results and was rife with controversy. But it is significant that it was a battle waged among a distinct group of men who shared a particular concern with systems, with the order of nature, and with the relation between the two.

It is clear then that any attempt to understand the abstractions of naturalists confronts us with a complex set of questions concerning, not only the circumstances and opportunities that made the abstracting activities of naturalists into a large-scale enterprise, but also the particular theoretical and epistemological ideals in terms of which these activities were justified. But it is also clear that in the work of Latour and Foucault the relevance of these two kinds of questions is judged very differently. However, before examining their points of view more closely, I will first describe in detail how circumstances, opportunities and ideals came together in the work of the two most illustrious naturalists of the eighteenth century. 


\section{References}

1. Diderot and d'Alembert, 1765, VIII, pp. 225-230.

2. François, 1952.

3. See also the article in the Encyclopedie on Natural History Cabinets. Diderot and d'Alembert, 1751, I, pp. 489-492.

4. Allen, 1976, chapter 1.

5. Ibid., p. 13.

6. Ibid., p. 30 .

7. Farber, 1982a, chapter 4.

8. Allen, 1976, p. 33.

9. Stafleu, 1971, chapter 6.

10. Ibid., p. 9.

11. Ibid., chapter 9 .

12. Daudin, 1926a, p. 59.

13. Quoted by Farber from the correspondence of the British naturalist Emanuel Mendes Da Costa. Farber, $1982 \mathrm{a}$, p. 50.

14. Ibid., chapter 2 .

15. Diderot and d'Alembert, 1751, II, pp. 489-492.

16. Allen, 1976, p. 39.

17. Daudin, 1926a, chapter 1.

18. Larson, 1971, chapter 1.

19. Daudin, 1926a, chapter 1 .

20. Ibid.

21. Sloan, 1972, p. 10 .

22. Quoted by Sloan from Cesalpino"s De Plantis Libri XVI (1583). Ibid . P. 10.

23. Ibid., p. 9.

24. Quoted by Larson from Cesalpino's De Plantis. Larson, 1971, p. 27.

25. Sloan, 1972, pp. 12-13; Larson, 1971, pp. 27-29.

26. Sloan, 1972, pp. 29-32.

27. Quoted by Larson from Ray's Methodus Plantarum Nova (1682). Larson, 1971, p. 36

28. Sloan, 1972, pp. 32-39

29. Quoted by Larson from Tournefort's Elemens de Botanique ou Mêthode pour connoître les Plantes (1694). Larson, 1971, p. 45.

30. Sloan, 1972, pp. 39-42; Larson, 1971, pp. 45-46.

31. Quoted by Sloan from Boerhaave's A Method for Studying Physick (1719). Sloan, 1972 , p. 51.

32. Quoted by Larson from Tournefort's Elemens de Botanique. Larson, 1972, p. 45.

33. Daudin, 1926a, p. 33.

34. Larson, 1971, p. 41. 
35. Quoted by Sloan from Ray"s De Variis Plantarum Methodis Dissertatio Brevis (1696). Sloan, 1972, p. 44.

36. Ibid., pp. $21-26$.

37. Larson, 1971 , p. 40.

38. Ibid., pp. $28-29$.

39. Quoted by Larson from Ray's Methodus Plantarum Nova. Ibid., p. 42.

40. Daudin, 1926a, pp. 48-65.

41. Farber, 1982a, pp. 7-14.

42. Quoted by Farber. Ibid., p. 10.

43. Daudin, 1926a, pp. 62-65.

44. Farber, 1982a, pp. 10-14.

45. Daudin, 1926a, p. 64.

46. Ibid., chapter 2 .

47. Ibid., pp. 105-110.

48. Ibid., p. 111.

49. Ibid, pp. 111-112.

50. Fleck, 1980. 


\section{LINNAEUS AND BUFFON}

\section{Two conceptions of science}

In the foregoing chapter I have described the practice of natural history: its relations with other practices like those of apothecaries, physicians and collectors; the attempts of naturalists to put the world in order through a process of systematic abstraction; and the aspirations of those who sought to reveal the true system of nature. Thus, it becomes clear that we cannot speak of a "science" of natural history in any straightforward way. The practice of natural history appears to be bound up with various activities and interests and it would be very difficult to draw a sharp line between that which was natural history proper and that which was not. Of course, we need not draw such a line, but at the time lines were drawn by others. Naturalists, that is, had their particular ideas on natural history as a scientific enterprise. Indeed, we might say that while a science of natural history was not simply present, there were many who attempted to create it, to gain it, to demarcate it in a world made up of plants, animals, minerals, cabinets, interests, fashions, pre-ideas, etc.

But how the line was drawn? How to make natural history into a veritable science? On this point, naturalists often seriously disagreed, and that cannot be illustrated better than by the work of two men whose names are bound up with the development of eighteenth-century natural history. Both Linnaeus and Buffon aimed at making natural history into a science, but, as we will see, their conceptions of science differed greatly, as did the nature of their abstracting activities. In this chapter I will describe and analyse these conceptions and activities in detail, to see what kind of abstractions did result from them.

\section{Linnaeus}

When Linnaeus arrived from Sweden in Amsterdam in 1735 he was already an experienced botanist. ${ }^{\prime}$ In 1730 , two years after he had started his medical studies at Uppsala University, he had been appointed as "docent" to demonstrate plants in the botanic garden to the medical students. In 1732 he made a journey to Lap- 
land with a travel grant from the Royal Scientific Society at Uppsala, studying plants and assembling a lot of information on the country. His first paper in 1730 had been an exposition of the sexual function of the stamens and the pistils in flowers, a theme which was discussed but not established at the time. ${ }^{2}$ In the same year he worked out a system of classification of plants, based on the stamens and pistills as the most essential parts. He also started writing a $F u n$ damenta Botanica, a book which was not devoid of reforming zeal, as the preface to the first manuscript version makes clear:

For when I first examined nature myself and saw her striving against the opinions of the savants, I laid aside all preconceptions, became a scepticus, and questioned atl, and only then were my eyes opened; only then did I see the truth. ${ }^{3}$

Arriving in Holland, Linnaeus obviously had more in mind than simply the acquisition of a degree at one of the Dutch universities. He had published almost nothing, but he carried with him several manuscripts in which he set out to work on "a broad front at a programme for the development of standards, not only of classification in the narrower sense, but also of nomenclature and description with its definitions and its terminological procedure". His first steps in Holland were to meet some well known scientists like Burman, who was in charge of the Amsterdam Hortus Botanicus, and Boerhaave, professor of medicine and botany at Leiden University. ${ }^{5}$ In Leiden, Linnaeus managed to meet with Boerhave and with Gronovius, a botanist of independent means who privately owned a considerable library and herbarium. The meeting was an immediate succes. The manuscript Systema Naturae that Linnaeus showed them, made such an impression, that Gronovius offered to pay for its publication. It appeared at the end of 1735 and contained neat tabular classifications of minerals, plants and animals into classes, orders, genera and species, with a number of aphoristic "observations" on each of these three kingdoms. ${ }^{6}$ The plants were classified according to the sexual system as it had been constructed by Linnaeus five years earlier. Published somewhat later as an appendix to the Systema was a methodus, which was introduced as:

The Method of Charles Linnaeus, the Swede, by which the Physiologist can accurately and successfully put together the history of each and every natural object. ${ }^{7}$

What followed were short instructions on how to describe the names of nat ural objects, how to the discuss the "theory", that is, the classification into classes, orders and genera, and further how to describe the genus, the species, and of each species the attributes, uses and literature. 
Things went smoothly now. Boerhaave recommended Linnaeus to Burman in Amsterdam, and at the express suggestion of Linnaeus himself, Gronovius advised the wealthy Amsterdam banker George Clifford to employ him as supervisor at Clifford's country seat near Haarlem. ${ }^{8}$ Clifford's estate, de Hartecamp, included gardens, orangeries, a rich library and a natural history cabinet. Linnaeus's main task was to catalogue the collections, to supervise the acquisition of new plants and to see to the publication of his own manuscripts. ${ }^{9}$ The rich resources now placed at his disposal were enthusiastically described by him two years later in the preface of his Hortus Cliffortianus:

My eyes were immediately delighted by so many masterpieces of nature put into relief by art - alleys, flower beds $s_{i}$ statues, pools and artfully constructed hills and labyrinths. I was spellbound by your menageries full of tigers, monkeys, wild dogs, Indian deer and goats, South-American and African swine; with their noises were those of a great quantity of birds ... I was dumbfounded when entering the hothouses, filled with so many plants that a son of the the North could not but feel himself enchanted and carried off to who knows what strange part of the earth. ${ }^{10}$

In addition to the Systema Naturae other manuscripts were published in short order. Thus, at the end of 1735, the earlier mentioned Fundamenta Botanica appeared, supported by Gronovius. The Fundamenta contained 36 pages with 365 aphorisms divided over 12 chapters in which, much more explicitly than in the Systema Naturae, the rules were given according to which plants had to be classified, described and named. ${ }^{11}$ Linnaeus, however, did not only introduce rules, he also showed how to apply them. In 1737 he published the Hortus Cliffortianus, containing systematic descriptions of plants from Clifford's collection according to his own principles, and further the Flora Lapponica with plants from Lapland. In the same year, Linnaeus published the Genera Plantarum in which he described 935 genera of plants - all the known genera of the world * of which 686 had been examined from living material. ${ }^{12}$ In his descriptions Lin" naeus referred to a total of thirty-eight organs or types of organs as "vegetable letters" which were used for the characterization of genera in conjunction with four "sound and constant mechanical principles": number, figure, position and relative size. Thus, Eriksson describes the Genera Plantarum as "the shining example from the Holland years of the capacity of the Linnean system to bring order to a large body of material and to make it easy to grasp. Using diagnoses of uniform pattern throughout, the plant kingdom is laid out in all its known diversity, genus by genus, in its ranks and classes. The definitions are unambiguous; everything is clear, definite, and extremely concise". 13 


\section{A process of organizing}

Linnaeus was a remarkable organizer. Even from the form of his publications, his pursuit of order becomes immediately manifest. He presented his thoughts in a series of aphorisms, grouped under different headings, using a minimum of words, very much in the way he organized his descriptions of natural objects. More than anyone else he must have been annoyed at the state of disorder in natural history of which he reported in 1737 :

Alas, What wide-spread wild confusion ensued towards the end of the last century, while the citizens of the commonwealth of Botany were distracted by internal strife beneath the triumvirate of Ray, Tournefort and Rivinus. ${ }^{14}$

Linnaeus did what many others had been doing before him. He proposed a new system, accepting the tradition stemming from Cesalpino, but using what he saw as the most essential parts of the flower. Parts, which appeared to fulfill the requirements of systematic classification in a conspicuous simple way. ${ }^{15}$ It was, as Eriksson observes, "the dream of young Linnaeus that, with his method, it would be possible for anyone who had learned the system to place any plant anywhere in the world in its right class and order, if not in its right genus, whether the plant was previously known to science or not". ${ }^{16}$

But Linnaeus did more than simply propose a system. He invented a whole array of terms designating in a very detailed and concise way the many different parts of plants. Instead of describing flowers as "the more delicate part of the plant" or "a filamentose and membraneous part of the plants, distinguished ... by its ... elegance", Linneaus characterized flowers in phrases like: "COR. Monopetalous, campanulated. Tube, very short. Limb ventricose, ... ". 17 What Linnaeus aimed at was an unequivocal statement of the "differentia", that is, a diagnostic enumeration of those essential characteristics which distinguish a plant from all others. As such, this was an established practice in botanical classification, but in Linnaeus's view it had to be applied with much more rigour. ${ }^{18}$ In fact, Linnaeus's organizing was directed to what Eriksson describes as "the curse of never knowing for certain whether two authors are talking about the same plant or different plants when they use plant names of their own and describe their genera and species in different words and with regard to different details and organs". 19

Which circumstances made for Linnaeus's succes? As we have seen, the question of how to organize the multiplicity of plants was a real one for many naturalists. And Linnaeus showed that he was an effective organizer using the very tools he had made himself. No one could match his productivity in describ- 
ing genera and species which, to use Eriksson's apt metaphor, "were fabricated according to the principles of serial manufacture, thus allowing mass production". ${ }^{20}$ Moreover, Linnaeus's decision to go to Holland was of enormous importance for his attempt to get his standards accepted. Because, as Stafleu points out, Dutch botany and botanists were leading taxonomy in the discovery and description of the extra-European plant world and Holland was a main centre of printing and publishing. ${ }^{21}$

So, Linnaeus's organizing reached further than the world of plants or animals. In Gronovius he had found an important ally, who supported his publications, who brought him into contact with Clifford, and who produced a flora of North American plants, the first work by an author other than Linnaeus himself $i_{1}$ : which the sexual system was followed. ${ }^{22}$ Next, Linnaeus sought to establish relations on a wider scale. He was especially eager to meet the Oxford professor Dillenius. ${ }^{23}$ Dillenius was planning a new edition of a classic source of plant names - Bauhin's Pinax - a work which stood in the herbalist's tradition and was originally published in 1623 . Linnaeus obviously considered Dillenius as a potential competitor of no mean importance. So, when he visited England in 1736, Linnaeus made an attempt to persuade Dillenius to adopt the genera of his own Genera Plantarum which had yet to be published. Although he had little success his failure was limited by the fact that Dillenius was never able to complete his work. Before returning to Sweden in 1738, there was still one thing which Linnaeus wanted to do: to visit Paris where Antoine and Bernard de Jussieu were in charge of the Jardin du Roy. ${ }^{24}$ This time, his stay bore fruit. Linnaeus was elected foreign correspondent of the Académie des Sciences, and somewhat later, in 1739, Bernard de Jussieu pronounced the Linnaean method preferable to that of Tournefort because it was more exact. ${ }^{25}$

\section{Natural history as a science}

What was Linnaeus's own interpretation of the process of organizing in which he was involved? In other words, what, for him constituted natural history as a science? His tenth observation on the three kingdoms of nature in the Systema Naturae contains a clear answer:

The first step in wisdom is to know the things themselves; this notion consists in having a true idea of the objects; objects are distinguished and known by classifying them methodically and giving them appropriate names. Therefore, classification and name-giving will be the foundation of our science. ${ }^{26}$ 
In a preceding observation Linnaeus has explained that all that is useful to man originates from natural objects, so that it is highly necessary to know how to select these objects for their use in the industry of mining or metallurgy, plant-industry or agriculture and horticulture, animal husbandry, hunting and fishing. In subsequent observations he also lists the virtues of plants and the use of animals. His main concern, however, is classification and name-giving, so:

He may call himself a naturalist, who well distinguishes the parts of natural bodies by sight and describes and names all these rightly in agreement with the threefold division. Such a man is a lithologist, a phytologist or a zoologist. ${ }^{27}$

Next, in his observations on the vegetable kingdom, Linnaeus decribes the foundation of botany as consisting of the division of plants and systematic name-giving, generic and specific, and he adds in the third observation that:

The lustre and achievement of the science is due to a very few botanists and among those especially to authors of systematics, whose example we should follow by continuing, improving and perfecting the systematic division of plants. ${ }^{28}$

Linnaeus, then, left little doubt about the place of the authors on systematics in the science of botany. In his Bibliotheca Botanica, a concise history of botany also written in a characteristic enumerative style, he even created a detailed classification of botanists, with two main divisions: the true botanists and the amateurs. The true botanists are either "collectores" (subdivided into nine categories) or "methodici". The methodici are divided by Linnaeus into "philosophers" and "systematists". The philosophers are considered theoretical botanists who lay down the canons and rules of botany: whereas the botany of the classics was a purely empirical knowledge, philosophers made it into a science by deduction from rational principles. The systematists, on the other hand, divide the plants into groups. According to Linnaeus, those who are "orthodox" establish their method on the true basis, that is, the fructification. "Heterodox" systematists are those who classify according to alphabet, roots, leafs, external appearance, medicinal properties, etc. Finally, the amateurs or botanophiles are those who make observations without direct relation to the science of botany, such as anatomists, gardeners, physicians, astrologers, chemists, etc. ${ }^{29}$ 


\section{System}

For Linnaeus natural history was the very science of classifying and naming natural objects. Without system, he said, botany would be chaos. Take an unknown plant from the Indies and compare the botanophile who looks in vain through descriptions and illustrations, to the systematist who will soon establish the genus, whether the old one or the new! Thus, a system will accomodate even the plants that have never been seen before. ${ }^{30}$

In the Philosophia Botanica of 1751, Linnaeus further explained his ideas on classification in a discussion of the aphorisms which were originally published in the Fundamenta. For example, what shall be the starting point of a classification? Linnaeus explains that:

A natural instinct tells us to know first the objects which are closest to us, and the smallest ones last, for example: man, quadrupeds, birds, fishes, insects, mites; or first the larger plants and last the tiny mosses. ${ }^{31}$

Linnaeus then explains that a system has to divide objects into classes, orders, genera, species and varieties. However, the institution of classes, orders and genera is "theoretical", in contrast to the establishment of species and varieties which is "practical". 32

As for the theory, Linnaeus refers to what he calls the invention of recent authorities that the fructification is the basis of classification of plants. ${ }^{33}$ The justification of this theory he has given already in the sixth observation on the vegetable kingdom in the Systema Naturae, where it is stated that:

The essence of plants consists in the fructification; of the fructification in the flower and the fruit; of the fruit in the seed; of the flower in the stamen and the pistil; of the stamen in the anthers; of the pistil in the stigma. ${ }^{34}$

Thus, Linnaeus took the orthodox point of view, but not without a qualification. Whereas Cesalpino based his classification on the fruit containing the seed and Tournefort used the corolla of the flower, Linnaeus argued that the flower precedes the fruit and that the essence of the flower consists in anthers and stigma constituting the sex in plants. ${ }^{35}$ Hence, his "sexual system" in which he based his classification principally on the number, form, proportion and situation of stamens and pistils. For example, Linnaeus divided the plants into twenty-four classes, eleven according to the number of stamens, the others according to the form, proportion or situation of stamens. For the division of classes into orders Linnaeus in some cases referred to pistils, in other cases to 
stamens and sometimes he used other criteria related to seeds, fruit or flowers. ${ }^{36}$

To Linnaeus the scientific value of his system seemed incontestable. He favoured his system as being neither "arbitrary" nor "heterodox". In an arbitrary system the number of subdivisions varied from one section to another as much as one needed, whereas in a well-defined system the number of subdivisions was fixed to five: class, order, genus, species and variety. Such a system did not fluctuate and so, in the words of Larson, "guided and supported the mind by providing a palpable, regular sequence of signs: ${ }^{37}$ Moreover, the sexual system was orthodox, based on essential characteristics and as such on the nature of things. Yet, whatever its scientific merit, Linnaeus made it clear that he would not call his method "natural", nor any other either. ${ }^{38}$ The sexual system had been primarily designed for rapid identification of the numerous genera and Linnaeus never saw it as more than a substitute for a true natural method. The system might be considered natural inasmuch as classes and orders were established on essential characteristics and thus often preserved apparently natural groups. The system remained artificial in that only a single part was used to determine all groups at one level.

\section{Genera, species and varieties}

We have seen how Linnaeus conceived of his botanical classes and orders, but what about his genera, species and varieties? As to the species Linnaeus stated in the Philosophia Botanica that:

There are as many species as the infinite being created diverse forms in the beginning, which, following the laws of generation, produced many others, but always simillar to them, therefore there are as many species as we have different structures before us today. ${ }^{39}$

The implications of this statement were twofold. First, species evidently were a stable, natural category, with their naturalness secured by the laws of generation. Second, in principle the recognition of species should be a straightforward operation, sorting out those forms which are similar. However, in practice the establishment of species demanded considerable skill because, as Linnaeus observed:

There are as many varieties as there are plants produced by the seed of the same species. 40 
In other words, individuals belonging to a species will always vary according to accidental circumstances. So, in identifying species, characteristics like colour and size are of no use and Linnaeus condemned those botanists who caused much confusion by erroneously describing varieties as species. In his view one could delineate the species only from "structures" like the roots, the stems, the leaves and the fructification. Again, one had to characterize these structures through number, figure, proportion and situation, that is, in such a way that they are always useable: in the living plant, in the herbarium and in the illustration. To bring out what is accidental in variation, Linnaeus also suggested that a botanist could possibly cultivate a species under different conditions. ${ }^{41}$

We can now understand why Linnaeus called the establishment of species and varieties practical: the reality of species was beyond any doubt and any experienced botanist could readily see them, so to speak. However, the establishment of genera was another matter. The following quotation from the preface to the Genera Plantarum is revealing:

Genera are as many as there are common attributes next (in rank) to those of distinct species, such as were created in the beginning: this is confirmed by revelation, experiment and observation. Hence all genera and species are natural. We must attentively and assidiously by observation inquire into the limits of genera. These limits may be difficult to determine, but confusion in genera means confusion in everything. Natural genera being assumed, there are two requirements for maintaining them sound: that only true species and no others be placed in the genus; that each true genus be circumscribed by limits and terms which we call the generic character. No authority except dissection in the herbarium should be acknowledged. ${ }^{42}$

For Linnaeus the genera were of the utmost importance. Classes and orders were the work of "nature" as well as "art" and, thus, it was possible to conceive of different systems, but the genera themselves were fixed and natural..$^{43}$ As such the genus was the basis for nomenclature: each species was named by a phrase stating its genus and the "differentia" through which it was distinguished from other species belonging to the same genus. Confusion of genera meant confusion of names, which was confusing everything. But, how to observe the genera of nature? Linnaeus answer was as follows:

We admit as many genera as there are different natural species of which the fructification has the same structure. ${ }^{44}$ 
In other words, the structure of the fructification contained the so-called "generic character". However, the generic character was definitely not derived from the presence of one or the other characteristic, it was conceived as a particular combination of a variety of characteristics. For the purpose of a detailed analysis of generic characters Linnaeus broke down the system of fructification into thirtyeight independent characteristics which, like the letters of an alphabet, could be found in various combinations. In Linnaeus his own words:

These marks are to us so many vegetable letters, which, if we can read, will teach us the characters of plants; they are written by the hand of God; it should be our study to read them. ${ }^{45}$

Moreover, the different marks could be described in number, figure, proportion and situation and from that Linnaeus concluded that his analysis would allow a total number of $38 \times 38 \times 4=5776$ possible combinations or generic characters, which, as he said, may never exist. ${ }^{46}$ Thus, every genus, old or new, could be readily assimilated in his system.

Linnaeus's assumption that there were fixed genera, which had been created as such and might be "read" from marks inherent in the fructification, makes it clear in which sense he deemed the constitution of his genera theoreticall. However, as so many naturalists before him, Linnaeus, too, indicated that in practice the "habitus" of plants - the parts other than those of the fructification was of great value as a check on the circumscription of natural genera. Linnaeus could not have been more explicit when he said that:

One must consult the habitus secretly, under the table (so to speak) in order to avoid the formation of incorrect genera. ${ }^{47}$

But at the same time, Linnaeus insisted that for the constitution of a genus it was neither admissible nor necessary to employ other characteristics than those taken from the fructification. Even so, in practice, botanists had to be flexible in the selection of these characteristics. Characteristics which were most reliable for the establishment of a genus in one case, sometimes had to be ignored in other cases in order to avoid splitting or lumping apparently natural genera. ${ }^{48}$ 


\section{The genus as a keystone}

Linnaeus's descriptions of genera in his Genera Plantarum appeared to be most successful, even more than his sexual system. The conception of a genus as an assemblage of species was not new to be sure, but with his standardized descriptions Linnaeus, as he said, erected a new building. ${ }^{49}$ For Linnaeus the genus evidently was a keystone. Yet, the way he described his genera can only be understood in relation to his search for system as a whole. First, as becomes clear from Linnaeus's prescriptions in the Philosophia Botanica, the constitution of a genus depended on the arrangement and description of species. According to Larson's account: "The naturalist first groups plants intuitively on the basis of habit ... From the chief or first species of the genus, [he] ... describes each element of fructification or vegetable letter by means of the four dimensions of number, figure, proportion, and situation. He then compares other species of the genus with the description of the first or chief species, and excludes from the description all marks in which they disagree". ${ }^{50}$ Linnaeus called the result of this procedure the "natural character" of the genus. In principle this natural character was fixed, although it might need amendment of course upon the discovery of new species: But this was not all. Linnaeus distinguished the natural character from that which was essential:

The essential charaeter distinguishes, by means of a unique idea, each genus from its neighbours in the same natural order. ${ }^{51}$

Knowledge of essential characters clearly was the ultimate aim, but was only possible if one knew the natural orders, that is, the natural system as a whole. In other words, if naturalists could bring genera together into natural orders, it would be possible to restrict descriptions to the "differentia" - those characteristics which essentially distinguish one genus from another within the same order. However, as long as knowledge of these natural orders was lacking, this could not be done and thus, in his descriptions of genera, Linnaeus stuck to natural characters.

So in Linnaeus's work the concept of genus strongly reflected the search for system dominating the botany of his time and his own conception of science. Linnaeus's descriptions of genera were not descriptions in any usual sense of the word. They were definitions in which the description of parts was restricted to those characteristics which, first, represented the nature of things and, second, were common to a group of species. In fact, Linnaeus wished to restrict his definitions even further to those characteristics which essentially distinguished each genus from other genera in the same natural order. His preoccupation with 
problems of order is very well illustrated in two comments which he added to his statement on essential characters:

The shorter a definition the better.

It is simple to learn the plants by their essential definition. ${ }^{52}$

The way in which Linnaeus described his characters, using dimensions of number, figure, proportion and situation, likewise illustrates his preoccupation with rapid identification on the basis of characteristics which could be exactly described, which were preserved in herbaria, and which could be represented in pictures. What he liked were:

... distinctions that are definite and capable of demonstration. ${ }^{53}$

\section{A natural method}

The relation between Linnaeus's concept of genus and his search for system needs some further qualification. For Linnaeus species and genera were unquestionably natural, but classes and orders he considered more arbitrary. ${ }^{54}$ Based as they were on the sexual system, classes and orders were created according to a single characteristic. Genera, on the contrary, had been created on the basis of multiple characteristics. In doing so, Linnaeus had relied upon some characteristics more than others, but which characteristic would be most reliable for the constitution of a genus could not be determined a priori. Characteristics or dimensions which appeared to be very constant and decisive in some cases need not be so in other cases. That is why Linnaeus considered each system in which plants were arranged according to a single, a priori criterium as artificial, that is, doomed to lead to arbitrary results. ${ }^{55}$ How then were Linnaeus"s natural genera related to his admittedly artificial sexual system?

First, Linnaeus emphasized that even in an artificial system it was often possible to preserve apparently natural groups. In his Classes Plantarum of 1738 he said:

A method which preserves more natural orders is more natural than one which keeps a smaller number of them intact. ${ }^{56}$

Hence, Linnaeus thought his sexual system to be superior to any other. It not only preserved all his natural genera, but also many generally accepted comprehensive "families" of plants. For Linnaeus this was no surprise, since his system 
was based on stamens and pistills, that is, on truly essential characteristics taken from the same structure which signified his genera. ${ }^{57}$ Of course, one might still charge the system with being artificial, but one should never forget that it effectively served an all-important purpose, that is, rapid and certain identification of natural genera. For Linnaeus, too, the natural method was the ultimate aim, but he compared those who rejected the artificial method to those:

... who pull down a useful vaulted building and build another in its place but cannot provide the roof of the vault. ${ }^{58}$

Thus, the natural method was a goal possibly once to be attained, but evidently not at short notice. What might be achieved were only "fragments" of such a method, of which Linnaeus said in the Philosophia Botanica that they must be sought with the greatest care. ${ }^{59}$ Linnaeus published a list of sixty-five natural orders as an example of such fragments and showed how these orders might be combined into even more basic natural groups. What were the reasons for Linnaeus to believe that these groups were natural? It was the habitus or general outward appearance of plants to which he referred, but at the same time he pointed out the dangers of such a procedure. General resemblances often were superficial and could easily result in the constitution of "unphilosophical" groups. ${ }^{60}$ So, as in the case of the genera, intuited groups had to be justified on the basis of the fructification. And again, Linnaeus observed, this justification would only succeed when no part of the fructification was singled out beforehand. The "character" of natural orders was to be sought in the "symmetry of all parts". ${ }^{61}$ However, Linnaeus expected that such a theoretical justification of natural orders would be feasible only through a more thorough analysis of the fructification. ${ }^{62}$

As so many of his fellow naturalists, Linnaeus obviously perceived a tension between an intuitively grasped conception of nature on the one hand, and a conception of method on the other. What circumstances stood in the way of a solution to this conflict? For Linnaeus insufficient knowledge of the fructification was only one reason and not the most important one. As he himself experienced almost daily, many more species had yet to be described, especially from areas outside Europe, and many genera were still unknown. Thus it was Linnaeus's opinion that:

The plants which are as yet unknown make the natural method incomplete; knowledge about them will bring it to perfection, because in fact nature makes no jumps. ${ }^{63}$ 
In other words, true natural orders and, for that matter, classes could only be delineated when all natural genera were known. The gaps which often erroneously suggest the reality of one or another group of plants will then be filled, because nature makes no jumps. So Linnaeus, too, accepted the idea of a continuity of being, although his metaphor was not a chain but a map, showing the groups at every level of a system, like the countries of the world, with relationships on all sides. ${ }^{64}$

\section{Linnaeus's zoology}

Linnaeus undoubtly saw himself in the first place as a botanist. Yet, he showed no less assurance as a zoologist and his programme for zoology was the same as that for botany. In the Systema Naturae of 1735 Linnaeus observed that, although animals were the highest and most perfect works of the Creator, zoology was much less worked up than the other two parts of Natural History. What he meant was that only a few, notably Ray, had tried:

... to reduce zoology to genera and species according to the rules of systematics. ${ }^{65}$

In the first edition of the Systema Naturae Linnaeus divided the animal kingdom into six classes: Quadrupeds, Birds, Amphibia, Fishes, Insects and Worms. These classes contained altogether twenty-five orders, nearly two hundred genera and over five hundred species. How had these groups been constituted? Again, apparently natural groups were intuited first of all on the basis of multiple resemblances between different forms. But, when classifying these groups, Linnaeus invoked a number of characteristics which he deemed decisive. ${ }^{66}$ For example, the Quadrupeds were defined as hairy, provided with four feet, the female being viviparous and suckling the young. Next, the Quadrupeds were subdivided into orders and genera principally with reference to teeth and mammae. In doing so, Linnaeus, unlike Ray for example, conferred on man a conspicious place in his classification of animals. Homo was the first genus of the Antropomorfa, a group which also contained the ape and the sloth and which headed the five orders of the Quadrupeds.

In subsequent editions of the Systema naturae Linnaeus's zoological classification underwent many revisions. Originally Linnaeus defined his six zoological classes on the basis of external characteristics. But in the greatly enlarged tenth edition of 1758 he revised these definitions, now referring principally to internal characteristics. In doing so he replaced the time-honoured class 
of the Quadrupeds by a class called Mammalia, which was defined by characteristics taken from the heart and the blood, but which was ultimately distinguished on the basis of viviparity. Linnaeus's Mammalia differed from the Quadrupeds in one interesting respect: his class included the Cetacea. From early days naturalists had noticed striking similarities between these aquatic animals and the Quadrupeds, but given the outward appearance of the former, they always had preferred to class them among the Fishes. In earlier editions of the Systema Linnaeus, too, had done so, but now that he had decided to emphasize internal characteristics in the definitions of his classes, he apparently dared to break with this established opinion. ${ }^{67}$

Linnaeus's reliance on a few decisive characteristics led to changes in other parts of his zoological classification as well. In the eleventh edition of the Systema for example, Linnaeus removed the sloth from the order Antropomorfa, which was renamed Primates and which contained, next to man and ape, the half-ape and the bat. Apparently, the latter genus was added by Linnaeus principally owing to the position of the mammae. Then, in a subsequent edition, a bat with two large cutting-teeth was transferred to the order Glires, containing the shrew and the rodents. ${ }^{68}$

There was another circumstance which regularly caused Linnaeus to revise his classification. The first edition of the Systema Naturae had contained over five hundred species. ${ }^{69}$ In the tenth edition of 1758 this number was increased to 4386 , followed by the eleventh edition in 1766 with 5897 species. In the forties and fifties Linnaeus had been able to consult several collections, especially those of the Swedish King and Queen, of which he also published a catalogue. Moreover, he had at his disposal collections donated to Uppsala University containing natural curiosities from Surinam, China, and the East Indies, collections which were further enriched through Linnaeus's extensive correspondence and especially through the missions of some of his own pupils to distant countries. ${ }^{70}$ Thus, Linnaeus had the opportunity to study a growing number of animal species and the results of this study often suggested to him the possibility for or the necessity of revising this or that part of his zoological classification.

The foregoing shows that for Linnaeus the need for a methodical classification was primary in zoology as well. As in botany, he attempted to found his classification on the choice of some essential characteristics, mostly taken from the external parts of animal forms. For example, when classifying one of the orders of his Worms - the Testacea - Linnaeus defined the genera on the basis of shells, ${ }^{71}$ independent from whatever knowledge he had of the creatures inhabiting these shells. It is true that in later editions of the Systema Naturae, Linnaeus referred more often to the internal parts of animals. But, with the exception of the Cetacea, this was a change of justification rather than of actual classifica- 
tion. In theory Linnaeus occasionally emphasized the relevance of internal characteristics, in practice he relied on the external ones as much as he could. His choice of characteristics obviously was primarily dictated by the need for a system which would allow easy identification, which meant that sometimes groups of animals were even characterized essentially by the absence of some specific characteristic, as for example the "wingless insects". ${ }^{72}$

Yet if Linnaeus appears to have organized his work in zoology very much like his botanical efforts, there was also a striking difference. In botany Linnaeus considered the genera and species as natural and certain, whereas he conceived the cllasses and orders as the products of art as much as of nature. In zoology, the situation was rather the reverse. The classes and orders were traditionally deemed most natural and, as Daudin points out, Linnaeus never felt the need for a deliberate artificial system because of his presumption that it was at the higher levels of classification that certainty reached it peak. ${ }^{73}$

\section{Buffon}

Who was Georges-Louis Leclerc de Buffon when he was appointed in 1739 to the post of Intendant at the Jardin du Roy in Paris? His first scientific credentials had been a mathematical paper on a game of chance which was published by the Academie Royale des Sciences and which gained him entry to this institution in 1733 . However, mathematics was not his only field of interest. ${ }^{74}$ In 1731 Buffon had managed to acquire by inheritance his father's lands in Burgundy, lands which comprised the estate of Montbard and the village of Buffon (which name he added to his family name). As soon as Buffon had taken up his residence in Montbard he began to exploit the various resources which had now become available to him. He established forges which he subsequently developed into a factory employing four hundred workers, producing all kinds of iron, such as guns for the army and navy and the gates for the Jardin du Roy. The forests which he owned gave him the opportunity to produce timber, a most important material in eighteenth-century France, used for fuel and for the construction of numerous artefacts. Moreover, the French King Louis XV had made several requests for the establishment of tree nurseries all over the country, partly in order to provide free fruit for the poor, and also to encourage employment in silk manufacture. The "Estates General" of Burgundy had reacted to these requests with the establishment of two nurseries and Buffon evidently saw a chance for new investments. He planted a nursery and two years later persuaded the deputies of the Estates to buy it for the province. He himself became its administrator and, with money of the Estates, turned it into a large scale enterprise. 
But there was more involved in Buffon's affairs than the mere production of guns and trees. ${ }^{75} \mathrm{He}$ also undertook a variety of investigations into the processing of ore and the growth of trees. His interest in the treatment of trees was stimulated by the Minister for the Navy, Maurepas, who had approached the Academie des Sciences in 1731 requesting that researches be conducted into the best means of conserving forests and producing timber suitable for maritime purposes. According to Goodman, Buffon "in his thousands of acres of woods ... systematically investigated the effects of frost on tree growth, the influence of the subsoil and of surrounding vegetation, and the optimum sites for planting". ${ }^{76}$ From the late 1730s Buffon's conclusions were published by the Académie des Sciences in several papers. Moreover, in 1735, Buffon had translated Vegetable Staticks, an English work published in 1727 by Stephen Hales, dealing with plant growth and chemical phenomena, and thus obviously important for Buffon's own research. In the introduction Buffon praised this work for being based on experiment, because:

C'est par des Expériences fines, raisonnées \& suivies, que l'on force la Nature à découvrir son secret; toutes les autres méthodes n'ont jamais réussi, \& les vrais Physiciens ne peuvent s'empêcher de regarder les anciens systèmes, commes d'anciennes rêveries ... Amassons donc toûjours des Expériences, \& éloignons-nous, s'il est possible, de tout esprit de systême, du moins jusqu'à ce que nous soyons instruits. ${ }^{77}$

Interestingly, Buffon's reservations about abstract knowledge were not only expressed in the context of his experimental work, they were also conveyed by his mathematical interest. When Buffon published a translation of Newton's Fluxions in 1740 , he regretted in a preface to this work that systems had been constructed on the concept of infinity which had only served to confuse facts and obscure ideas. That is, whereas some had taken infinity as something real, infinity was only an abstraction from what is real. As such, it was no more than a supposition that might sometimes help us to simplify our ideas and to generalize our results in the practice of science. ${ }^{78}$

For Buffon the practice of science clearly had to be oriented to concrete phenomena, and as we have seen, in his hands it was also in many ways a practice at the crossroads of commercial and political interests. Such interests were often fostered from Paris, the centre of political power and of scientific activities, a centre from which Buffon, staying at Montbard, apparently felt too far removed. So, in order to sustain his various activities, he soon made it a practice to live in Paris during the winter months. ${ }^{79}$ There he succeeded in making contact with many well-known scientists and also with men representing the power of the Court, like the earlier mentioned minister Maurepas. Much later, in 1788, 
Condorcet would remark in his eulogy on Buffon that he was someone who clearly knew how to "navigate":

Monsieur de Buffon avait le soin constant d'acquérir et conserver du crédit auprès des ministres et de ceux qui, chargés par eux des détails, ont sur la décision et l'expédition des affaires une influence inévitable. Il se conciliait les uns, en ne se permettant jamais d'avancer des opinions qui pussent les blesser, ou ne paraissant point prétendre à les juger, il s'assurait des autres en employant avec eux un ton d'égalité qui les flattait. ${ }^{80}$

When in 1739, Dufay, the Intendant of the Jardin du Roy, suddenly fell serious$1 y$ ill and died, Buffon indeed showed his skill of navigation. Writing from Montbard, he asked his friend and colleague at the Académie des Sciences, Helliot, to act on his behalf. The latter not only approached the Minister Maurepas, but also managed to obtain a letter from Dufay in his final hour, in which Buffon was recommended to the King as the future Intendant. ${ }^{81}$.Thus, Buffon was appointed to fill up the vacant directorship and was further elected Associate of the botanical section of the Académie des Sciences. ${ }^{82}$

\section{Creating an institution}

When Buffon took up the position of Intendant at the Jardin du Roy, this institution was just recovering from a long period of decline. ${ }^{83}$ Originally founded for instruction on the medicinal virtues of plants, the garden and its collection of drugs had always been directed by the prime physician of the Court. Dufay had been the first Intendant with the exclusive task of maintaining the Jardin and Cabinet du Roy and he had taken initiative toward a process of reconstruction. At the time of Buffon's arrival, the Cabinet, according to François, contained no more than "un savoureux mélange de fruits des Indes, de drogues en bocaux, de quadrupèdes, de poissons, d'armes et de vêtements 'de sauvages', le tout réparti dans des armoires vitrées, dans les tiroirs ou suspendu au plafond de deux petites salles ... Les herbiers, formés par Tournefort, ... riche ... de 14000 plantes séchées, étaient, faute de place, déposés dans la chambre du démonstrateur de Botanique". ${ }^{84}$

As Intendant, Buffon first of all undertook to enlarge the Cabinet. ${ }^{85} \mathrm{He}$ entered into correspondence with naturalists all over Europe, inviting them to send living animals or skins, plants, minerals or observations on these subjects. He also appealed to the growing number of amateurs in natural history, to travellers and in particular to officials in the colonies. Buffon further encouraged those 
amateurs actively contributing to the growth of knowledge, by persuading Louis $\mathrm{XV}$ to create the honorific title of "correspondant du Cabinet du Roy". As a result, the collection of the Cabinet rapidly increased and problems of space soon became pressing. Buffon created more room by abandoning part of his own appartments and, in 1745, he appointed Louis Daubenton, a physician from Montbard, who as "garde et démonstrateur du Cabinet" was charged with arranging the growing collections. Moreover, by the early 1740's, Buffon had begun work on what he described, in a letter of 1744 , as a historical catalogue of an immense cabinet of natural curiosities. ${ }^{86}$

In 1748 it appeared from the publisher's prospectus that the planned catalogue would equal the cabinet in its immensity. ${ }^{87}$ Fifteen volumes were announced by Buffon and Daubenton, in which all of the history of the earth, animals, plants and minerals would be treated. The year 1749 witnessed the publication of the first three volumes of what was called the Histoire naturelle, générale et particulière, avec la description du Cabinet du roy. The first two volumes contained a general programmatic statement on "the manner of studying and expounding natural history", in addition to discussions of the theory of the earth, of theories of plant and animal generation, and of the natural history of man, all written by Buffon. The third volume contained descriptions by Daubenton of those parts of the Cabinet which were relevant to the natural history of man, and further discussions by Buffon on the human senses and of the varieties within the human species.

While the contents of these first three volumes were by no means undisputed, the work would become very popular. As a consequence Buffon obtained new possibilities to add "curiosities" to his already large assets. ${ }^{88}$ In the Histoire naturelle he had been careful to mention the name of everybody who had been willing to supply specimens for the Cabinet and this proved to be a powerful incentive. What was still more important was that Buffon's efforts made the Cabinet du Roy into a site for material brought back by government expeditions, for bequests to the Crown from collectors, and for precious gifts from foreign monarchs. For example, when it appeared that Reaumur, who died in 1757 , had bequeathed his famous collection to the Académie des sciences, Buffon intervened and arranged for its transference by royal ordinance to the Cabinet du Roy. Buffon was especially interested in Réaumur's birds, since he had planned a section on birds in his Histoire naturelle and, as Farber observes, "it was not to Buffon's interests to have the Réaumur collection mined by someone outside his enterprise". ${ }^{89}$ Moreover, the Cabinet du Roy was not rich in birds, partly because of inadequate methods of preservation. 
What Buffon eventually created was not only the largest natural history collection in eighteenth-century Europe, it was an institution that in 1788, the year of his death, comprised an elaborate network of collaborators throughout the world and that occupied a site twice as large as in 1739 , with greatly extended buildings. Profiting from the constant influx of discoveries and observations from travellers, explorers and correspondents, and also from the descriptions supplied by his own collaborators at the Jardin du Roy on the basis of the constantly enlarged collection of materials, Buffon made his Histoire naturelle into an enterprise unequalled for its scope. Although Buffon, after the publication of the first three volumes, had intended to treat all the warmblooded quadrupeds in two volumes, his descriptions ended up by occupying twelve volumes, to be completed only in 1767. The subsequent nine-volume Histoire naturelle des ofseaux, originally intended to occupy only a single tome, was undertaken with a variety of collaborators, and appeared between 1770 and 1783. The histories of oviparous quadrupeds, of fishes and of cetaceans were only brought to completion after Buffon's death and much of the remainder of the original project, as for example the whole domain of botany, was never to appear.

Buffon"s Histoire naturelle was firmly rooted, we might say, in the institution of the Jardin and Cabinet du Roy. As such, the contents were not free from the typical problems of order which were inherent in the arrangement of a cabinet or, for that matter, in natural history as a whole. As I have described in the foregoing chapter, Daubenton, in his descriptions of the Cabinet du Roy, extensively discussed the question of the correct arrangement of collections of natural objects. For his part, Buffon stressed the necessity of bringing some order into the chaotic state of nomenclature, for instance stating in an article on the bustard that:

\begin{abstract}
La première chose que l'on doit se proposer lorsqu'on entreprend d'eclaircir l'histoire d'un animal, c'est de faire une critique sévère de sa nomenclature, de démêler exactement les différens noms qui lui ont êté donnés dans toutes les langues \& dans tous les temps, \& de distinguer autant qu'il est possible, les espèces différentes auxquelles les mêmes noms ont été appliqués; c"est le seul moyen de tirer parti des connoissances des Anciens, \& de les lier utilement aux découvertes des Modernes, \& par conséquent le seul moyen de faire de véritables progrès en Histoire Naturelle. ${ }^{91}$
\end{abstract}

For Buffon, however, problems of identification were not the heart of the matter. On the contrary, anyone who devoted all his energies to the construction of systems of classification could count on Buffon's scorn. So, the prospectus for the Histoire naturelle des oiseaux announced that the author of this work did 
not wish to imitate the "puerile pedantry" of the nomenclaturists. ${ }^{92}$ Indeed, Buffon's Histoire naturelle looked very different from the works of a Linnaeus. Instead of the tabular classifications of the Systema Naturae or the concise definitions of the Genera"Plantarum, Buffon presented his readers with eloquent descriptions of animals in their natural habitat, giving details of their life histories, food, and other aspects concerning their habits and virtues. Daubenton supplemented these discussions in articles providing anatomical descriptions. ${ }^{93}$ Moreover, the descriptions were illuminated by beautiful plates, in the case of birds even colour plates. Yet; despite its sumptuous design, Buffon"s work pretended to be much more than a popular encyclopedia of natural history. Buffon, as we will see, did have a genuine interest in problems of order, but it was an interest which, to use Farber's words, "went considerably beyond the confines of a "nomenclaturist" "94

\section{A true science of natural history}

What is to be done if we want to apply ourselves seriously to the study of nature? What makes natural history a science? Buffon opened the first volume of the Histoire naturelle with a discussion of these questions in a long discourse on "the manner of studying and expounding natural history".95 To begin with, Buffon told his readers what a true science of naturall history was not. Briefly, it was not the reduction of nature to the status of petty systems. Methods in natural history could indeed be very useful in facilitating work and assisting the memory. But it seemed that, in particular for botanists, the search for a general system had become the search for a kind of "philosopher's stone". Yet the establishment of such a system was clearly impossible since any division of the whole of nature into classes, genera and species would necessarily lead to arbitrary results. That is:

.... la Nature marche par des gradations inconnues, \& par conséquent elle ne peut pas se prêter totalement à ces divisions, puisqu'elle passe d'une espèce à une autre espèce, \& souvent d'un genre à un autre genre, par des nuances imperceptibles; de sorte qu'il se trouve un grand nombre d'espèces moyennes \& d'objets mi-partis qu'on ne sçait où placer, \& qui dérangent nécessairement le projet du système géneral. ${ }^{96}$

However, what in Buffon's view contributed most to the arbitrariness of systems was the freedom which botanists had allowed themselves in choosing this or that feature of plants as a distinguishing characteristic. So, instead of describ- 
ing plants in all aspects, botanists had desired to judge a whole on the basis of a single part. And who could fail to see that:

cette façon de connoître n'est pas une science, \& que ce n'est tout au plus qu'une convention, une langue arbitraire, un moyen de $s^{\prime}$ entendre, mais dont il ne peut résulter aucune connoissance réelle? ${ }^{97}$

Of course, Buffon's argument was only too familiar. Like so many of his fellow naturalists, Buffon conceived of a continuity of being, a conception which often appeared to be at variance with a search for system. As he said, all that might be, actually is. Thus, whoever places himself at the head of all created beings, will see with astonishment:

qu'on peut descendre par des degrés presqu'insensibles, de la créature la plus parfaite jusqu'à la matière la plus informe, de l'animal le mieux organisé jusqu' au minéral le plus brut. 98

For Buffon this point of view implied that naturalists should not restrict their minds by trying to fit everything within the dividing lines of a system. That would amount to creating abstract definitions of things, and naturalists would cease to see objects as they really are. What was needed was the precise description and the accurate history of each thing. The sole true science, as reasonable people knew, was knowledge of facts. Facts which, in the case of animals, must relate to all aspects of the whole organism as well as to those of the entire species. Facts concerning form, size, weight, colours, external as well as internal organs, and also the history of generation, the number of young, place of habitation, food, usefulness to man, etc.

However, for Buffon the acquisition of facts was only a first step. While it stood to reason that in the study of natural history one had to start with bringing together various specimens from different regions for the purpose of making detailed observations, it was also plain that:

lorsqu'on est parvenu à rassembler des échantillons de tout ce qui peuple l'Univers, lorsqu' après bien des peines on a mis dans un même lieu des modèles de tout ce qui se trouve répandu avec profusion sur la terre, \& qu'on jette pour la première fois les yeux sur ce magasin rempli de choses diverses, nouvelles \& étrangères, la première sensation qui en résulte, est un étonnement mêlé d'admiration. 99 
Some collectors indeed seemed to be satisfied with just filling their rooms with curiosities, but what was needed for a disciplined study of natural history was more than collecting and observing. Equally necessary, according to Buffon, was a grand view which takes everything in its sweep. What Buffon in fact proposed was the following: first, we may accept as natural some great divisions like Animal, Vegetable, and Mineral, and Four-footed Animals, Birds and Fishes. Second, we consider these groups in view of their relations with the life of man, first studying the horse, then the dog, followed by the ox, etc.

Buffon admitted that such a method was arbitrary. But was it more arbitrary than placing together, as Linnaeus had done, the horse and the zebra only because these animals are soliped? Was it not better to have the horse followed by the dog, which indeed customarily follows it, rather than the zebra, which is little known to us? And what was more arbitrary than to put together beings as different as man and the sloth? Why call the lynx a species of cat, the fox and the wolf species of dog, onlly because there are some small resemblances between the number of mammary glands and teeth of these animals? In fact, Buffon said, what exists in nature are only individuals, while genera, orders, and classes only exist in our imagination. So:

ne seroit-il pas plus simple, plus naturel \& plus vrai de dire qu'un âne est un âne, \& un chat un chat, que de vouloir, sans sçavoir pourquoi, qu'un âne soit un cheval, \& un chat un loup-cervier? ${ }^{100}$

In the last part of his discourse, Buffon made it clear that the issues involved in his discussion of system and method in fact reached far beyond the particulars of natural history. In his earlier work he had already conveyed his reservations about "abstract" knowledge compared to knowledge of the "real". In the final pages of the initial discourse, this theme recurred in an explicit distinction between "mathematical" and "physical" truths. Mathematical truths, according to Buffon, were nothing more than abstract consequences of equally abstract suppositions or definitions, that is, nothing more than identity of ideas. As such they were intellectual and arbitrary and had nothing to do with the real. Physical truths, on the other hand, did not depend on man-made suppositions, but were generalizations of observed facts. In Buffon's own words:

Les phểnomènes qui s'offrent tous les jours à nos yeux, qui se succèdent \& se repètent sans interruption \& dans tous les cas, sont le fondement de nos conoissances physiques. ${ }^{101}$ 
How were these two kinds of truth related to each other? Physical truths rested in the repeated succession of events in time and so were considered by Buffon a question of probability. In his view, mathematics could be applied to assure the certainty of a recurrence of events. But this union of mathematics and physics could be accomplished only if one could deal with phenomena in an abstract manner, stripping them of almost all physical qualities, like the movements of the planets in the Newtonian universe. In natural history, Buffon evidently considered it impossible to deal with the observed phenomena in such a formal way. Were one to do so, real knowledge would be unjustly replaced by symbolic expressions and learned phrases, as in systems of classification in which the objects of natural history were turned into abstract entities having no relation to real beings.

Buffon thus perceived the methods of nomenclaturists as completely arbitrary. But what about the method which he himself proposed? Was he not saying that his own method of studying natural history was arbitrary too, that a naturalist ought to study natural objects in the most convenient way, judging them by the connections which they have with his own life? However, what Buffon wished to suggest here was not the notion that all classification was conventional, it was rather the idea that knowledge was principally relative to man, that the limited power of the human senses restricted the understanding of the world. That is:

tout ce qui nous est possible, c"est d'apercevoir quelques effets particuliers, de les comparer, de les combiner, \& enfin d'y reconnoître plutôt un ordre relatif à notre propre nature, que convenable à l'existence des choses que nous considérons. ${ }^{102}$

For Buffon this point of view by no means implied that true knowledge of the real was impossible. Through systematic observation, comparison and combination of particular effects man could acquire knowledge of "general effects", and these general effects were what Buffon considered to be the very laws of nature. Such laws were the quintessence of physical truth and were the ultimate aim of a true science of natural history. If this aim would be followed by everyone, then:

on cesseroit de disputer, \& on se réuniroit pour marcher dans la même route à la suite de l'expérience, \& arriver enfin à la connoissance de toutes les véritếs qui sont du ressort de l'esprit humain. ${ }^{103}$ 


\section{A concept of species}

The many subsequent volumes of the Histoire naturelle were an obvious attempt to carry out the ambitious programme of the intitial discourse. How far did Buffon achieve this aim? The second volume, also published in 1749 , opened with a general discussion of the natural history of animals, in which Buffon denoted the "species" as an unquestionably real, but also elusive phenomenon:

ce n'est pas dans l'individu qu'est la plus grande merveille, c'est dans la succession, dans le renouvellement \& dans la durée des espèces que la Nature paroît tout-à-fait inconcevable. Cette faculté de produire son semblable, qui réside dans les animaux \& dans les végétaux, cette espèce d'unité toújours subsistante \& qui paroît éternelle, cette vertu procréatrice qui s'exerce perpétuellement sans se détruire jamais, est pour nous un mystère dont il semble qu'il ne nous est pas permis de sonder la profondeur. ${ }^{104}$

Species were eternal and fixed, showing a continual and mysterious succession of similar individuals. Thus, Buffon presented the species as the most fundamental entity of nature. Although his concept of species concurred with that of other naturalists like Ray, Réaumur and, as we have seen, Linnaeus, it seems that Buffon was especially attracted to this concept because it referred to a clearly observable and recurrent phenomenon - the succession of similar individuals in time - and so represented a veritable example of a physical truth. ${ }^{105}$ As Sloan has pointed out, a later statement of Buffon in an article on the ass, contained in the fourth volume of the Histoire naturelle, is very suggestive in this respect. There it is said that:

l'espèce est ... un mot abstrait \& général, dont la chose n'existe qu'en considérant la Nature dans la succession des temps, \& dans la destruction constante \& le renouvellement tout aussi constant des êtres: c'est en comparant la Nature d'aujourd'hui à celle des autres temps, \& les individus actuels aux individus passés, que nous avons pris une idée nette de ce que l'on appelle espèce ... C'est donc dans la diversité caractéristique des espèces que les intervalles des nuances de la Nature sont le plus sensibles \& le mieux marqués ... puisqu'on peut toûjours tirer une ligne de séparation entre deux espèces, c'est-à-dire, entre deux successions d'individus qui se reproduisent $\&$ ne peuvent se mêler ... ce point est le plus fixe que nous ayons en Histoire Naturelle, toutes les autres ressemblances \& toutes les autres différences que l'on pourroit saisir dans la comparaison des êtres ne seroient, ni si constantes, ni si réelles, ni si certaines; ... chaque espèce, chaque succession d'in- 
dividus qui se reproduisent \& ne peuvent se meler, sera considérée à part \& traitée sêparément, \& nous ne nous servirons des familles, des genres, des ordres \& des classes, pas plus que ne s'en sert la Nature. ${ }^{106}$

So although there was indeed a similarity between Buffon's concept of species and that of Linnaeus, there was also a difference and one which is very revealing in the light of Buffon's earlier statements in the initial discourse. Linnaeus's conception of species as individuals related by the laws of generation was clearly subsidiary to the theoretical constitution of genera as the basis of definition and nomenclature of the multiplicity of species. For Buffon, on the other hand, the concept of species was acceptable only because it referred to relations existing in nature in the succession of time, whereas in his opinion the concept of genus remained abstract and thus devoid of physical truth, because it referred to no more than a few arbitrarily chosen resemblances between individuals. To be sure, such resemblances were clearly informative in establishing species, but only when they were taken from all the different parts of the organisms as a whole. Even then Buffon considered these resemblances of only secondary importance. Thus, he stated in his general discussion of the natural history of animals that, first of all:

... on doit regarder comme la même espèce celle qui, au moyen de la copulation, se perpétue $\&$ conserve la similitude de cette espèce, \& comme des espèces différentes celles qui, par les mêmes moyens, ne peuvent rien produire ensemble. ${ }^{107}$

\section{A theory of generation}

The statement that the ability of self-replication seemed to be a mystery escaping human scrutiny, did not prevent Buffon from considering the phenomena of reproduction at great length in his general discussion of the natural history of animals in the second volume of the Histoire naturelle. ${ }^{108}$ Moreaver, his reasoning on these phenomena was again clearly related to his argument in the initial discourse. Thus, Buffon considered the phenomena of reproduction as particular effects which had to be explained in terms of a more "general effect". His question was: what is the secret mode by which Nature enables different bodies to propagate their own species? Buffon then presented a detailed hypothesis which comprised three suppositions and which appeared to cover even more than the phenomena of reproduction. First, it was supposed that there was an infinity of incorruptible organic particles actually existing in nature and con- 
stituting the substance of organized bodies. Related to the first was a second supposition saying that each organized body was assembled by these organic particles according to its own particular form through the effect of a so-called "internal mould". However, not so much these internal moulds were actively combining masses of organic particles into organized bodies, but an active power possessed by these particles themselves caused them to penetrate and incorporate within these moulds. Hence, a third supposition was advanced, claiming the existence of very active qualities in nature, which, like gravity, penetrated bodies to the most internal parts. Thus, it was Buffon's hypothesis that:

... de la même façon que la force de la pesanteur pénètre aussi dans l'intérieur de toute matière, de même la force qui pousse ou qui attire les parties organiques de la nourriture, pénètre aussi dans l'intérieur des corps organisez, \& les y fait entrer par son action, \& comme ces corps ont une certaine forme que nous avons appelée le moule intérieur, les parties organiques poussées par l'action de la force pénétrante ne peuvent y entrer qué dans un certain ordre relatif à cette forme, ce qui par conséquent ne la peut pas changer, mais seulement en augmenter toutes les dimensions, tant extérieures qu'intérieures, \& produire ainsi l'accroissement des corps organisez \& leur développement; \& si dans ce corps organisé, qui se developpe par ce moyen, il se trouve une ou plusieurs parties semblables au tout, cette partie ou ces parties, dont la forme intérieure \& extérieure est semblable à celle du corps entier, seront celles qui opéreront la reproduction. ${ }^{109}$

Thus, nourishment, growth, and propagation were effects of one and the same cause. In terms of this hypothesis, Buffon explained the phenomena of reproduction as effected by particles which, being shaped by the mould of an organized being, are sent to the generative organs and so reproduce this mould into a new being. In his view, it was this process which constituted the essence of the unity and continuity of the species. In the fourth volume of the Histoire naturelle, Buffon elaborated on this idea in an article on the horse in which he stated that:

Il y a dans la Nature un prototype général dans chaque espèce sur lequel chaque individu est modelé, mais qui semble, en se réalisant, s'altérer ou se perfectionner par les circonstances; en sorte que, relativement à de certaines qualités, il y a une variation bizarre en apparence dans la succession des individus, \& en même temps une constance qui paroît admirable dans l'espèce entière: le premier animal, le premier cheval, par example, a été le modèle extérieur, \& le moule intérieur sur lequel tous les chevaux qui sont nés, tous ceux qui existent, \& tous ceux qui naîtront ont été formés. ${ }^{110}$ 
So, through the generative succession of individuals from a first model, the putative internal mould constituted, in Buffon's view, a cause or general effect which in spite of ubiquitous individual variation assured the reality of the species. Buffon, however, did not wish to stop at grand hypotheses, On the contrary, what had to be done, as he said, was to collect facts. Thus, in connection with his theory of generation, he presented a series of microscopic observations on seminal fluids of different origins, which, in his view, showed the truth of this theory, But this was only a beginning. The products of these generative processes - the species - still had to be carefully studied and described one by one.

\section{On the degeneration of animals}

What Buffon aimed at in his Histoire naturelle was indeed no more and no less than a full description of each species. Man he had already discussed in the second and third volumes of 1749 . In the fourth volume of 1753 followed descriptions of the horse, the ass and the cow, being domesticated species familiar to man. For Buffon the reality of these four species was beyond question. The different varieties of man could reproduce together and so constituted a single species. On the other hand, the horse and the ass were evidently distinct because of the infertility of the mule. ${ }^{12}$ In his article on the ass, already quoted above, Buffon explicitly rejected the point of view of those naturalists who had established a relation between the horse and the ass by uniting these creatures into a "family" or "genus" solely on the basis of the number of resemblances. Such "families of reason" were only an aid to our understanding and were not to be considered real, unless it could be shown that these animals could successfully interbreed, which in fact would imply that they were not distinct species, but one. To decide this question, Buffon actually performed experiments at Montbard from 1751 onwards, which in the case of the horse and the ass appeared to have had negative resuits. ${ }^{113}$

Buffon also pointed out the danger of unjustly splitting up groups of animals into different species on the basis of "accidental" differences presumably acquired under the influence of differences in climate, food or habits. Such influences he supposed to be particularly strong in the case of domesticated animals as the dog. ${ }^{114}$ Here again, the breeding criterium was clearly of fundamental importance in recognizing real relationships. Thus, it was Buffon's programme in natural history to recognize the unity of species without being deceived by conspicuous resemblances or differences between different animals. This programme was a means to order the multiplicity of forms, relating them to fundamental "types", while at the same time explaining them as the result of a 
process of "degeneration" caused by physical influences leading to the establishment of distinct varieties. As a result, Buffon distinguished and described two hundred species of quadrupeds, undoubtly constituting in his view a more natural classification than all the artificial classifications of the nomenclaturists. ${ }^{115}$

However, when carrying out this programme, things sometimes appeared more complex than expected. While Buffon considered the breeding criterium decisive in establishing species, it was often unknown to what extent interbreeding occurred or could be achieved. For example, was the roe, which much resembled the goat, perhaps a "wild goat"? And what about the multitude of species among the small quadrupeds, species which often much resembled each other? Were they true species or only varieties? ${ }^{116}$ Moreover, when by 1757 , Buffon acquired Réaumur's bird collection and he began to prepare his natural history of birds, the problem of the sheer number of species became pressing. Describing the birds one by one would clearly be impossible. Thus, as his work progressed, Buffon tended to unite those species which closely resembled each other into groups which he called "families" or "genera", suspecting that these species might well interbreed or in any case might have degenerated from a common stock. ${ }^{117}$

Lack of knowledge on the occurrence of interbreeding could sometimes be overcome by performing experiments, but even then it appeared that the decision on how to delimit a species was not easy. For example, it was known that goats and sheep could produce offspring. But, when Buffon in 1755 wrote an article on the goat in the tenth volume of the Histoire naturelle, it was undecided whether mulets were fertile or not. Buffon thus considered these animals as separate species, but also started to perform experiments in which goats and sheep were crossed. ${ }^{118}$ It then appeared that these crossings could lead to fertile offspring. Yet, they were successful only in one direction, that is, only when a billy-goat was mated with a sheep. In ambiguous cases like this, Buffon maintained that one had to do with distinct species, but again suggested the possibility of a common origin. ${ }^{119}$ So, by 1764 , when writing on sheep, he stated that:

... nous avons altéré, modifié, changé ... des animaux domestiques: nous avons donc fail des genres physiques $\&$ réels, bien différens de ces gentes métaphysiques \& arbitraires, qui n'ont jamais existé qu'en idée; ces genres physiques sont réellement composés de toutes les espèces que nous avons maniées, modifiées \& changées; \& comme toutes ces espèces différemment altérées par la main de $l^{\prime \prime h o m m e, ~} n^{*}$ ont cependant qu'une origine commune \& unique dans la Nature, le genre entier ne doit former qu'une espèce. ${ }^{120}$ 
The twelfth volume of the Histoire naturelle opened with a general article, titled "De la Nature. Première vue", to be followed one year later with a "Seconde vue ${ }^{11}{ }^{121}$ In these articles, Buffon, after so many volumes with descriptions of individual species, again explicitly discussed the broad conception of order underlying his natural history. In the "Premiere vue" he emphasized that:

la Nature ne s'écarte jamais des loix quỉ lui ont êté prescrites; elle n'altère rien aux plans quil lui ont êté tracés, \& dans tous ses ouvrages elle présente le sceau de l'Eternel: cette empreinte divine, prototype inaltérable des existences; est le modèle sur lequel elle opère, modèle dont tous les traits sont exprimés en caractères ineffaçables, \& prononcés pour jamais; modèle toujours neuf, que le nombre des moules ou des copies, quelqu'infini qu'il soit, ne fait que renouveler. ${ }^{122}$

Buffon repeated here what he had been saying earlier, that in each species the first individuals served as a fixed type for all their descendants. However, in the subsequent "Seconde vue", he stressed more strongly than he had done before, that during the perpetual succession of individuals in time, all species were subject to variation. The implications of this observation soon became clear in an article on "the degeneration of animals" which appeared in 1766 in one of the closing volumes on the quadrupeds. ${ }^{123}$ In this article, Buffon first gave a description of environmental conditions causing "change, alteration and degeneration" of animals, followed by several examples of such change. But then he wrote:

... après le coup d'oeil que l'on vient de jeter sur ces variétés qui nous indiquent les altérations particulières de chaque espèce, il se présente une considération plus importante \& dont la vue est bien plus étendue; c'est celle du changement des espèces mêmes $s_{*} c^{\prime} e s t$ cette dégénération plus ancienne \& de tout temps immémoriale, qui paroît s'être faite dans chaque famille, ou si l'on veut, dans chacun des genres sous lequels on peut comprendre les espèces voisines \& peu différentes entr'elles. ${ }^{124}$

To be sure, Buffon had earlier voiced suggestions that the process of degeneration might produce different species where originally there had been only one. But these suggestions had been casual, and a more definite statement had only appeared in relation to domesticated animals, which were supposed to have been changed through the hand of man. Now, in 1766, Buffon was suggesting more clearly that this change of species was a general phenomenon. The results of such a change he conceived of as genera or families, including several species which were hierarchically related to each other: one being the first model or 
"trunk", with the others being "collateral branches". In the article on degeneration Buffon thus arranged a great many of his two hundred species into twentyfive more or less inclusive genera.

As we have seen, when Buffon began writing the Histoire naturelle, he saw no point in bringing together the horse and the zebra only because they were soliped. By 1766 , he considered these two species, together with the ass, as members of one family, on the argument that between these animals there were infinitely more resemblances than differences and also that they were the only ones which were really soliped. However, these were not his only arguments. Buffon further argued that, although these animals were distinct species, with the horse being the principal trunk and the zebra and the ass collateral branches, they were not really separate. In contrast to what he had written earlier, Buffon now explained at great length that the putative sterility of the mule was a preconceived opinion. If one took the trouble to do experiments, one would soon find out that on certain conditions crossings between the horse and the ass really could produce fertile offspring. As to the zebra, there were neither observations nor experiments to which Buffon could refer. But he held it probable that this animal, if one would succeed to soften its savage and recalcitrant nature, would produce offspring with the horse as well as with the ass. ${ }^{125}$

The dog, of which Buffon originally had written that it was most natural to describe it together with the other domesticated animals familiar to man, now appeared as member of a genus including the wolf, the fox, the jackal and the arctic fox. According to Buffon, the resemblances between these species were so striking that it was difficult to understand why these animals did not reproduce together. Experiments in which it was attempted to mate dogs with the wolf or the fox had not been successful. For Buffon, however, this was no reason to deny the reality of the genus. He observed that it was the savage nature of the wolf as well as its state of captivity which prevented the acceptance of the domesticated dog, and he suspected that dogs in more natural circumstances would mate with the wolf as well as with the fox. On the other hand, he had reasons to believe that the wolf and the fox never mated. So, he considered these two species as the major branches of the genus, produced by a degeneration older than the memory of man, with the dog, jackal and arctic fox forming intermediate lateral branches. ${ }^{126}$

When Buffon enumerated all the genera and isolated species which he had distinguished in this way, he designated each of them in terms of a few conspicuous characteristics, referring to animals which are "soliped", animals which have "cloven hoofs and horns", animals which are "carnivorous with claws having retractable nails", etc. He further distinguished these genera and species into those which were found in the Old World, those which were found 
in the New World and those which were found in both. Buffon then attempted to reduce the number of groups even further by relating New World animals to Old World ones on the basis of the number of resemblances, whereby he finally speculated that at some time the Old and New World had been one. ${ }^{127}$

\section{A world of types}

As the number of animals which Buffon studied and described increased, his ideas on their relationships evidently changed. The sources of this change were at least three: information on matings between different animals; the need to organize the description of the very many species of little animals; and the growing information on New World animals brought to Europe by explorers. ${ }^{128}$. What changed was not Buffon's disgust at the abstractness of relations based on a few resemblances, but his growing belief in the very comprehensiveness of real relations that induced him to establish inclusive genera of animals. He came to conceive of a world in which the diversity of beings was subject to continuous change, constituting a continuity of forms with linear as well as lateral relationships. ${ }^{129}$

Buffon did not conceive this change as boundless however. In his view, all organized beings were reproduced from a first model and as such constituted constant species. As he allowed more and more change on the level of species, the first model was elevated to a higher plane, constituting whole genera, with each species belonging to one genus bearing the imprint of the same, permanent mould. For Buffon, the change of animals undoubtly became an important phenomenon, but in his opinion natural history continued to be a science which had to reveal the very order and constancy behind this change. What this meant to him became clear once more in his Epoques de la nature, a detailed account of the history of the earth, which was published in 1778 as one of the supplements to the Histoire naturelle. In this history, Buffon explained how the cooling earth had created suitable conditions for the formation of organic particles under the influence of heat. Then, determined by a particular temperature, these particles had combined into organized beings through the formation of internal moulds. In Buffon's view, this process was not unique to the history of the earth. On the contrary, it was a process that was effected according to universal laws, whereby an unchanging world of eternal types would be revealed always and everywhere when certain conditions would be met. ${ }^{130}$ 


\section{The art of abstracting}

In the beginning of this chapter I have suggested that both Linnaeus and Buffon were involved in abstracting activities. However, was it not Buffon who rejected abstractions as improper to natural history as a science? Certainly he did, but, now that I have described his work beside that of Linnaeus, it becomes clear that the difference between the two was not simply a matter of the presence or the absence of abstractions. What really was at issue were the kind of abstractions that would reveal the realities of nature. In the foregoing chapter I argued that the abstracting activities of naturalists reflected pre-existing ideas concerning the order of things, the circumstances and opportunities that made these activities into a large scale enterprise, and, not to be forgotten, the particular theoretical and epistemological conceptions of naturalists themselves. So, it is interesting to analyse and compare the abstracting activities of Linnaeus and Buffon, to see in what sense they were similar or different, and how these similarities or differences were related to the kind of conditions and conceptions mentioned.

As we have seen, Linnaeus reconstructed his genera of plants starting from groups which any trained botanist might recognize at first sight, that is, on the basis of general outward appearance. However, such a method was only a help to be invoked "under the table"' as he said; it could never justify the definition of natural genera. For Linnaeus a "natural" entity was something that was created as such, and which had to be defined by a statement of its essence. In other words, like Cesalpino, Linnaeus identified the nature of things with their essence, and according to his own theory, the essence of plants consisted in the fructification, in particular the stamens and pistils. Thus it was on general epistemological grounds combined with a particular theoretical point of view, that Linnaeus thought it justified to represent his genera by "natural characters" taken from the fructification. But there was another consideration which allowed him to push the process of abstraction even further. If genera were embodied in a well-defined system of classes, orders, genera, species and varieties, it would be possible to define them only by those essential characteristics which distinguished each genus from the others in the same order. But this step obviously demanded the definition of natural orders which, for the present, Linnaeus did not think feasible. Thus, he was content with his sexual system, representing classes and orders principally by the number, form, proportion and situation of stamens or pistils, and so serving the need for ready identification of a growing number of genera.

As the last point makes clear, Linnaeus"s abstracting activities were also motivated by the increasing scale of classifying activities. As we have seen, 
problems of organization abounded as more naturalists became involved in collecting and arranging plants or animals in gardens, herbaria or cabinets, leading to a proliferation of descriptions, names and systems. Linnaeus strongly felt the need to standardize the method of describing, naming and classifying, and in doing so, he succeeded in representing a whole variety of natural objects in concise formulae, related to each other in an all-embracing system. Thus, Linnaeus created order in the world of natural history. His abstractions organized plants, animals, minerals, and as we will see, naturalists as well.

Linnaeus"s epistemological and theoretical point of view concurred nicely with a need for concise and easy to grasp descriptions. After all, a few essential characteristics were all that was needed to represent the nature of a plant or animal. But we have seen that the content of his descriptions was also shaped by the particular circumstances in which the abstracting activities of naturalists took shape. In botany, Linnaeus vindicated characterizations in terms of number, figure, proportion and situation; indicating that they were usable in the living plant as well as in herbaria. In zoology, he evidently preferred the use of external characteristics which, essential or not, were readily noted and were preserved in a cabinet. Thus, Linnaeus's abstractions reflected the perceptions and interests of what we might call a cabinet naturalist.

But what about Buffon? He was one of those very cabinet naturalists. $\mathrm{He}$ made the Cabinet du Roy into the largest collection of eighteenth-century Europe. He should have been worried about problems of order more than anyone else. Buffon, indeed, did take an interest in order, but what occupied his mind were not methods or systems proper to a "nomenclaturist". For him, much more than for Linnaeus, the question was how our knowledge of the world could be epistemologically justified. For Buffon, an understanding of the essence of things was impossible. All that was given to us was knowledge of "general effects". Happily, natural history offered ample opportunities to study such effects: the ability of self-replication, leading to the endless succession of similar individuals, undoubtedly was the most intriguing example.

Buffon did not deny that species were abstractions: what existed in nature were only individuals. But, these abstractions he considered both epistemologically and theoretically justified. Epistemologically, because the succession of similar individuals in time suggested a general effect and theoretically, because this effect could be explained by the phenomenon of generation. In theory, that is, the ability of self-replication revealed the existence of a "mould", explaining the striking constancy in the succession of individuals, whereas at the same time each individual was subject to change through the contingent action of food, climate and habit of life. But how could one establish species in practice? Evidently, Buffon accepted many of the species that traditionally had been distin- 
guished on the basis of general outward appearance. But he also made it clear that it was the ability to reproduce that had to be decisive. Thus, his progranme in the Histoire naturelle was to establish species by abstracting, from the variety of individual forms, groups that could reproduce together, ignoring, as it were, the resemblances and differences between individuals. However, we have seen that during the many years in which Buffon worked on this programme, his abstracting activities underwent a gradual but significant change.

In part, this change may be related to the circumstances in which these activities took place. More often than not it was impossible to decide if animals could reproduce together, especially in the case of wild animals and the numerous species of little quadrupeds or birds. So, to delineate his species, Buffon relied more and more on resemblances and differences related to the general outward appearance of animals. In his descriptions of birds, Buffon also invoked such resemblances as a means to resolve the problem of the scope of the material which had to be covered. On the basis of resemblances, that is, he reduced the multitude of species to a restricted number of genera. The establishment of these genera of course signified another more sweeping attempt at abstraction. In his final discussion of the quadrupeds Buffon had already made it clear that he thought such abstractions perfectly justified. Buffon, in fact, gradually changed his mind about the phenomena of organic change, providing his abstracting activities with a new theoretical foundation. Species were now perceived as the products of long-term processes of "degeneration", sometimes older than the memory of man. Different species thus originated from one and the same mould, constituting what Buffon considered as real physical genera.

\section{Types and laws}

Whatever the differences between the abstracting activities of Linnaeus and Buffon, there is also a conspicuous similarity if we focus on the abstractions which ultimately resulted from these activities. Both Linnaeus and Buffon accepted the idea that there were natural groups of plants or animals and from these groups they somehow abstracted distinct types. The "character" of a Linnaean genus, we might call indeed a type or general plan, common to a group of species. ${ }^{131}$ In other words, species were perceived as variations upon the type of a genus and it was the task of a naturalist to abstract these types from the variety of beings. Buffon actually called the internal mold or imprint of each species a:

... type dont les principaux traits sont gravés en caractères ineffaçables \& permanens à jamais. 132 
Thus, when Buffon discussed species, and later in his work, more comprehensive genera of animals, he too abstracted types from a multitude of forms.

An even more striking similarity appears if we consider the way in which Linnaeus and Buffon defined their types. Both, in fact, referred to some salient characteristics taken from the external parts of animals. In the case of Linnaeus that was inherent, of course, in the nature of his project: finding easily visible characteristics that would allow a methodical classification. So, he defined the genera of his Quadrupeds or Mammalia principally with reference to mammaries. But when Buffon, in his turn, brought together the quadrupeds into larger genera, he likewise defined them by a few characteristics taken from external parts, like hoofs, horns and nails. Of course, that does not mean that their conception of these genera was the same. What it shows is that both Linnaeus and Buffon had to work with collections or descriptions which often had no more to offer than information on external parts.

Types, then, reflected the particular circumstances in which Linnaeus and Buffon were working, but they were also shaped by the completely different meanings which Linnaeus and Buffon assigned to them. For Linnaeus, types revealed the essential nature of beings. In his view, the character of a genus defined the essence of a group of species, just as the character of an order had to define the essence of a group of genera. In this way Linnaeus sought to establish a hierarchical system of essential definitions, revealing the workingplan or laws according to which orders, genera and species had been created. The naturalist who wished to find these laws had to divide the world of natural objects into orders, genera and species on the basis of variations in the very structure in which these essentials were contained.

In the eyes of Buffon, however, such a system had nothing to do with laws, but only with purely logical relations imposed upon nature by man. Buffon did not deny the existence of some intelligible order, but such an order evidently had to be conceived of in terms of the only relations which he considered real, that is, the successional relationships between individuals. ${ }^{133}$ Such relations might, if necessary, be established by the number of resemblances taken from individuals as a whole. But what really united animals or plants into species or genera was a generational bond, going back to the first individual in which the type of a species or genus had been realized. Thus, the real laws of nature became manifest in the constant destruction and renewal of beings, showing, in the midst of continual change, the perpetual repetition of unalterable types. Obviously, it was in the history of each species or genus that these laws had to be found. 


\section{Conclusion}

In the foregoing I have attempted to show that the abstractions of Linnaeus and Buffon reflected various practices and beliefs. On the one hand, I have emphasized the circumstances which affected the nature of their abstracting activities, in particular the way in which these activities were bound up with the practice of collecting. On the other hand, I have highlighted their own particular interests, especially their beliefs concerning the nature of science. Of course, it is often difficult to make such a distinction in an unambiguous way. We have seen, for example, that Linnaeus's search for essentials concurred very well with the need for methodical classifications and it is difficult to make out to what degree this search might even have been inspired by it. We have also seen that Buffon's acceptance of comprehensive genera cannot be wholly detached from the need to organize large amounts of material. In other words, it is not always easy to determine whether the abstracting activities of naturalists were dictated by circumstances from which it was difficult to escape, or proceeded from independent considerations concerning the very nature of science.

Whatever its difficulties, the distinction is interesting, especially because it was referred to by naturalists themselves. Naturalists, that is, often discussed their own abstractions in epistemological terms, drawing a distinction between knowledge that was conventional and that was real. Real knowledge was of course the ultimate goal of natural history as a science. But in practice conventional forms of knowledge might be acceptable too. Systems, for example, were accepted by many as a necessary if conventional device to help the memory. In other words, naturalists justified these systems with reference to particular circumstances in natural history. But for those who wished to make natural history into a science, the question remained if and how the resulting abstractions could be justified with reference to nature. Hence, the preoccupation of Linnaeus and Buffon with distinctions like "artificial" and "natural", "abstract" and "real". Linnaeus and Buffon obviously agreed that such distinctions had to be made, but how to make them was another matter!

Now that I have described the various activities and considerations that shaped the abstractions of eighteenth-century naturalists, we can return to the work of Latour and Foucault for a first discussion of the questions that I posed in the Introduction. It is clear that in accounting for these abstractions, Latour and Foucault will point to different aspects of the foregoing history and will relate these aspects in different ways. To a certain extent, we might say that Latour will be especially interested in all those aspects which I have summarized as circumstances and opportunities that made the abstracting activities of naturalists into a large scale enterprise. That is, from a Latourian point 
of view, we should pay particular attention to the heterogeneous means through which plants, animals and stones were rendered mobile, stable and combinable. Foucault, on the other hand, asks us to relate the possibility of a natural history to conditions and concerns that are epistemological rather than practical. In his view, means are only important insofar as they reveal to us the underlying rules which in the classical age delimited what might count as a true classification. Let us now examine the results of a first confrontation of these two views. 


\section{References}

1. Stafleu, 1971, chapter 1 .

2. Eriksson, 1983.

3. Quoted by Eriksson. Ibid., p. 75.

4. Ibid., pp. 76-77.

5. Stafleu, 1971, chapter 1.

6. Linnaeus, 1735.

7. Quoted after Schmidtl 1952.

8. Eriksson, 1980.

9. Stafleu, 1971 , chapter 1 .

10. Quoted by Boerman. Boerman, 1980, p. 50 .

11. Stafleu, 1971, chapter 2.

12. Eriksson, 1983.

13. Ibid., p. 81.

14. Quoted by Sloan from a translation of Linnaeus's Critica Botanica. Sloan, 1972, p. 50.

15. Larson, 1971, chapter 2.

16. Eriksson, 1980, p. 58.

17. Stafleu, 1971, p. 51; Larson, 1971, p. 89.

18. Stafleu, 1971, chapter 3.

19. Eriksson, 1980, p. 59.

20. Ibid., p. 61.

21. Stafleu, 1971, chapter 6.

22. Ibid., chapter 6 .

23. Eriksson, 1980.

24. Stafleu, 1971, chapter 1.

25. Larson, 1971, chapter 2.

26. Linnaeus, 1735 , p. 19.

27. Ibid., p. 19: Twelfth observation on the three kingdoms of nature.

28. Ibid., p. 22.

29. Stafleu, 1971, pp. 35-43.

30. Ibid., pp. 62-63.

31. Quoted by Stafleu. Ibid., p. 60.

32. Ibid., p. 58.

33. Ibid., p. 58.

34. Linnaeus, 1735, p. 23.

35. Ibid., p. 23: Observations seven to eleven on the vegetable kingdom.

36. Larson, 1971, pp. 55-58.

37. Ibid., p. 61. See also Daudin, 1926a, pp. 39-43.

38. Stafleu, 1971, p. 120. 
39. Quoted by Stafleu. Ibid., p. 63 .

40. Quoted by Stafleu from the Philosophia Botanica. Ibid., p. 63.

41. Ibid.; pp. 88-89.

42. Quoted by Stafleu. Ibid, p. 75.

43. Ibid., p. 67.

44. Quoted by Stafleu from the Philosophia Botanica. Ibid., p. 66.

45. Quoted by Larson from the Genera Plantarum. Larson, 1971, p. 77.

46. Stafleu, 1971 , p. 70.

47. Quoted by Stafleu from the Philosophia Botanica. Ibid., p. 70.

48. Tbid., pp. 70-72.

49. Ibid., p. 76 .

50. Larson, 1971, p. 84.

51. Quoted by Stafleu from the Philosophia Botanica. Stafleu, 1971, p. 73. See also Larson, 1971, pp. 90-91.

52. Quoted by Stafleu from the Philosophia Botanica. Ibid., p. 73.

53. Quoted by Larson from the Critica Botanica. Larson, 1971, p. 79.

54. Stafleu, 1971, p. 75.

55. Daudin, 1926a, pp. 41-43.

56. Quoted by Stafleu. Stafleu, 1971, p. 126.

57. Ibid., pp. 120-124.

58. Quoted by Stafleu after a translated text from the Genera Plantarum. Ibid., p. 135.

59. Ibid., p. 45.

60. Larson, 1971, pp. 63-65. See also Daudin, 1926a, pp. 43-46.

61. Stafleu, 1971, p. 129.

62. Larson, 1971, pp. 70-71.

63. Quoted by Stafleu from the Philosophia Botanica. Stafleu, 1971, p. 46.

64. Ibid., p. 45 .

65. Linnaeus, 1735 , p. 26 : from the second observation on the animal kingdom.

66. Daudin, 1926a, pp. 65-78; Carus, 1872, pp. 492-521.

67. Daudin, 1926b, chapter 2, pp. 122-134.

68. Lönnberg, 1909, pp. 24-25.

69. Smit, 1980.

70. Ibid. See also Lönnberg, 1909, p. 21.

71. Daudin, 1926a, pp. 75-76. See also Carus, 1872, pp. 513-514.

72. Ibid., pp. 73-78.

73. Ibid., p. 70.

74. Bertin, 1952, pp. 92-95; Goodman, 1980, pp. 5-11.

75. Ibid.

76. Goodman, 1980, p. 9 .

77. Quoted from the text of Buffon"s preface reproduced in Piveteau, 1954, pp. 5-6. 
78. Lyon and Sloan, 1981, p. 46.

79. Bertin, 1952.

80. Quoted by Bertin. Ibid., p. 98.

81. Ibid., pp. 98-99.

82. Lyon and Sloan, 1981, p. 6.

83. François, 1952.

84. Ibid., pp. 106-107.

85. Ibid. See also Farber, 1982a, pp. 14-26.

86. Lyon and Sloan, 1981, p. 6.

87. Tbid., p. 6.

88. François, 1952; Farber, 1982a, 14-26.

89. Farber, 1982a, p. 15.

90. Lyon and Sloan, 1981, p. 7.

91. Buffon, 1771, Histoire naturelle des oiseakx, II, pp. 1-2. See also Farber, 1982a, p. 19.

92. Farber, 1982a, p. 23.

93. Lyon and Sloan, 1981, p. 7.

94. Farber, 1982a, p. 25.

95. Buffon, 1749, I, pp. 3-62. For the following account I relied on John Lyon's English translation of the initial discourse in Lyon and Sloan, 1981, pp. 97-128. For a general and very interesting discussion of Buffon's ideas on natural history see Roger, 1963, pp. 525-542. See also Wohl, 1960; Sloan, 1976; and the introduction in Lyon and Sloan, pp. 132. I was not able to consult Roger's recently published biography of Buffon.

96. Ibid., p. 13.

97. Ibid., p. 16.

98. Ibid., p. 12.

99. Ibid., p. 5.

100. Ibid., p. 40.

101. Ibid., p. 57.

102. Ibid., p. 12.

103. Ibid., pp. 61-62.

104. Buffon, 1749, II, pp. 2-3. See also Farber, 1972, p. 262.

105. Sloan, 1976.

106. Buffon, 1753, IV, pp. 384-386. See also Sloan, 1976, p. 370.

107. Buffon, 1749, II, pp. 10-11. See also Farber, 1972, pp. 262-263.

108. Ibid., especially pp. 18-73. For my account of Buffon's ideas on reproduction I rèlied on the English translation of relevant texts in Lyon and Sloan, 1981, pp. 170185. For an interesting discussion of Buffon's theory of generation see also Roger, 1963 , pp. 542-558. 
109. Ibid p. 46.

110. Buffon, 1753, IV, pp. 215-216. See also Farber, 1972 , p. 266.

111. Lyon and Sloan, 1981, pp. 187-209.

112. Roger, 1963 , p. 567 .

113. Sloan, 1976, pp. 372-373. See also Farber, 1972, p. 268.

114. Dechambre, 1952.

115. Roger, 1963, pp. 566-567.

116. Ibid, pp. 570-571.

117. Farber, 1972 , pp. $269-272$ and 279.

118. Ibid., p. 268.

119. Roger, 1963, p. 572-573.

120. Buffon, 1764, XI, p. 369. See also Farber, 1972, p. 273.

121. Buffon, 1764, XII, pp. i-xvi; 1765, XIII, pp. i-xx. See also Farber, 1972, pp. 273-274.

122. Ibid., p. iv.

123. Buffon, 1766, XIV, pp. 311-374. See also Farber, 1972, pp. 275-278.

124. Ibid., p. 335 .

125. Ibid., pp. 335-347.

126. Ibid., pp. 349-354.

127. Ibid, pp. 355-374.

128. Farber, 1972, pp. 268-272.

129. Roger, 1963, p. 565. See also Daudin, 1926a, pp. 166-169.

130. Ibid., pp. 577-582.

131. Stafleu, 1971, p. 26.

132. Buffon, 1765, XIII, p. ix.

133. Sloan, 1976. 


\section{SOCIOLOGICS OR LOGIC?}

\section{A Latourian view}

The history which I have outlined in the foregoing chapters may be described as a development from local to global classifications. The botanical classifications of apothecaries in seventeenth-century London may be considered as local because they included only a limited number of plants which were mainly of local origin and because such classifications were typical of the particular preoccupations of apothecaries. On the other hand, the classifications of eighteenth-century naturalists like Brisson, Linnaeus or Buffon, may be conceived as global in the sense that the search for order now included many more different species from many more different parts of the world. Of course, a relativist may rightly point out that these "global" classifications too, were typical of the particular preoccupations of a small group of naturalists, that is, a community or culture which was neither more nor less local than the community of seventeenth-century apothecaries or the culture of a savage tribe from New Guinea. Indeed, the number of classification systems almost equalled the number of naturalists!

In his book Science in Action, Latour agrees with this relativistic stance, but not without an important qualification. We may follow relativists in their so-called symmetric approach of any elaim to knowledge (scientific or not), but in doing so, we must not forget that scientists continually strive to make their claims more credible than those of others. Naturalists, indeed, especially were out to convince each other of the superior credibility of their own classifications. Linnaeus, for example, was very successful in this respect and from a Latourian point of view it becomes a crucial question how the asymmetry between the system of Linnaeus and that of London apothecaries was created. This is a question which is hardly ever posed. Historians of biology, it is true, tell us about the battles waged inside the community of naturalists, but not about the way in which scientific classifications have triumphed over those of apothecaries."

Inasmuch as Latour discusses natural history in his book as an example, it is not difficult to find his answer to the question posed above. ${ }^{2}$ The answer is not that scientific classifications are more rational than those of savages or apothecaries. If we wish to understand the difference between these classifications 
we must, according to Latour, first of all direct our attention to the ships which during the seventeenth and eighteenth centuries sailed to the West Indies, Cape of Good Hope or other, still unknown places in the world. In the case of the latter destinations, travellers were confronted with unknown coasts, people, plants and animals. But, who knew these coasts, people, plants and animals better than the native inhabitants? Here, a "local" savage was much stronger than the crew of a ship that had been strong enough to withstand the oceans. The savages knew the treacherous shoals, poisonous plants, and cannibalistic tribes better than anyone else. However, the officers of a ship attempted to learn as much as they could: coasts were surveyed, latitudes, longitudes and depths were noted down, savages were questioned, plants and animals were gathered. Thus, unknown places were taken away, so to speak, first to a ship and then to Amsterdam, Lisbon or Paris. Other ships were built, manned, provisioned, armed and sent away. What was unknown to an earlier crew, now was known and predictable. Coasts and shallows, manners and customs, plants and animals, had been mapped and described. Now, even before sailing, a formerly unknown land could be seen and so, the crew of each succeeding ship was more prepared and stronger than a previous one.

Latour talks about a cycle of accumulation, whereby things which are far away, invisible and unknown, are brought back to a centre where they are made known, well-ordered and predictable so that others may be sent again to bring other things back. Only when this cycle is maintained, when ships are not wrecked, crews are not killed or rise in mutiny, only then can particular points and lines be added to a map by someone in Amsterdam, Lisbon or Paris, and only then can the next ship be stronger than the previous one. However, as Latour makes clear, that is not all. For the construction of a map it was not enough to bring back personal diaries from faraway lands, what was really needed were co-ordinates: latitudes and longitudes. So, ships were equipped with clocks, quadrants, sextants and with people who knew how to use these instruments. Only by coding every sighting did it become possible to bring back huge and distant mountains, coasts and bays in a sufficiently neat tabular form so as to be able to reduce them in a centre to the convenient proportions of an atlas.

Latour concludes that the cartographers in a centre became stronger than a local savage, indeed became familiar with more parts of the world than anyone else, as more and more distant places were rendered mobile, stable and combinable. Places were rendered mobile by means of ships and their crew, stable by means of instruments and paper, and combinable by means of standardized procedures according to which instruments were used and observations were put on paper. It is, according to Latour, only a little step from the work of cartographers to that of naturalists. The shape of a land could only be rendered mobile 
by inscribing it in the notebook of a navigator, but plants, animals and stones could be gathered during expeditions and taken away in ships, packed like "new Noah's Arks". But, stability was a problem: seeds had to be protected against desiccation, skins had to be safeguarded from insects, etc. It was only insofar as such problems were solved that the surface of the world could be, as Daubenton put it in the Encyclopédie, "abbreviated" and "flattened" in gardens and natural history cabinets.

From this Latourian perspective, it becomes interesting to look at the work of the aforementioned French naturalist Brisson, the demonstrator of Réaumur's famous natural history cabinet. ${ }^{4}$ In addition to his Règne Animal divisé en IX classes, Brisson published an Ornithologie, a work which set a new standard for the classification of birds and in which he described fifteen hundred species and varieties, three times as many as in Linnaeus's tenth edition of the Systema Naturae. How can we understand the strength of Brisson's taxonomic work? For a Latourian observer it is clear what the answer must be. Reaumur's network of correspondents and his preservation method increased the mobility and stability of birds which were seen rarely, or only in distant countries, and allowed his cabinet to become a centre where someone could compare all these birds at ease by going from one case to another by taking a few steps. Moreover, Brisson's work further increased the mobility and stability of the birds in Réaumur's cabinet. His descriptions, often accompanied with illustrations, could be compared by other naturalists with birds from collections elsewhere, or again with descriptions based on these collections, without it being necessary to visit Réaumur's cabinet. Now, a naturalist only had to turn a few pages! $!^{5}$ Brisson"s work was also important in another respect. He standardized his many hundreds of descriptions in such a way that naturalists could compare them almost at a glance, a method which of course further enhanced the combinability of birds into a system of classification.

As Daubenton reminds us in the Encyclopédie, preliminary to any science is a vocabulary which allows for the naming and description of objects in terms which are understood by every author. ${ }^{6}$ Nothing was more important in this respect than the work of Linnaeus, who owed his success largely to the neat way in which he standardized his botanical descriptions, thus rendering plants combinable to an unprecedented degree. We have seen how Linnaeus invented a whole array of terms designating in a very detailed and unequivocal way the many different parts of plants, a procedure which enabled him to characterize all known genera and species in comparable, very concise phrases. Thus naturalists attempted to render plants and animals ever more mobile, stable and combinable and here we have, according to Latour, the clue to the riddle of the asymmetry between the classifications of eighteenth-century naturalists and those of savages and apothecaries. Thanks to this very mobility, stability and 
combinability, and to nothing else, a handful of naturalists was able to compare plants and animals on a scale which was totally different from that of a savage or apothecary. Why did naturalists see things that had never been seen by anybody else? Because by opening a few cases or turning a few pages naturalists visually dominated a world that nobody could command in the space and time of everyday life.

What is fascinating in Latour's account is the way in which he attempts to describe the activities of scientists - not only of cartographers and naturalists, but of all scientists - in terms of the same three concepts: mobilisation, stabilisation and combination. In doing so, Latour especially emphasizes the heterogeneity of the activities and means that allow mobility, stability or combinability to be improved. If we only study the ultimate result of these activities we will most probably be impressed by the abstract and esoteric nature of scientific work. However, for Latour, the projections of cartographers or the definitions in a classification system are merely the tip of the iceberg. Such abstractions are neither more nor less than the very last steps in an endless chain of activities in which things are mobilised; stabilised and combined. In following that chain we end up everywhere: shipyards, chart rooms, instrumentmakers, kings, trading companies, oceans, winds, the sun, stars, gardens, cabinets, savages and apothecaries.

For Latour then, it is clear that in the study of science we must not proceed from distinctions like those between science, technology, politics, economics, nature, etc. But neither must we adopt a purely relativistic stance, since the abstractions of science are unquestionably different from our claims in everyday life. Those abstractions are different, not because they are the result of a peculiar intellectual activity, but because they are the sum, the nth re-representation of an extensive network of statements, things and phenomena. Latour reminds us that even scientists do not have especially huge brains. So, as more and more elements are mobilised, stabilised and combined, scientists can only handle them by representing these elements in a neatly arranged, abstract way. The more extensive the network of statements, things and phenomena, the more abstract the representations required!

Again, the experiences of naturalists may serve as an example. As more and more ships were sent away, more unknown places were explored, more exotic plants and animals were brought back and more people started to collect, naturalists got more and more involved in difficult questions of order. In other words, the more that plants and animals were rendered mobile, stable and combinable, the more they accumulated in gardens, herbaria and cabinets, leaving the observer with a feeling that Buffon has so nicely described as "bewilderment mixed with admiration". ' Worlds had been mobilised, but that was clearly not enough to make naturalists stronger than savages or apothecaries. Only by 
enhancing the mobility, stability and combinability of plants and animals still further, would it be possible to take in everything at a glance. Thus, plants and animals were pictured and described in books and catalogues. However, as Linnaeus observed, with books full of illustrations and descriptions it is still utterly impossible to gain a comprehensive view. Without system natural history would be chaos. Hence, he set himself the task to represent the world of plants and animals in an all-embracing system in which only the most important characteristics would be maintained: pistils and stamen, teeth and nipples. The shorter the definitions the better! Thus, a chain of the most heterogeneous activities, in which plants and animals were rendered mobile, stable and combinable, ended in the abstract formulae of a classification system.

\section{Foucault on natural history}

"Abstract" thinking, according to Latour, is a phenomenon not to be opposed to "concrete" action, but to be studied as its very result. We should not marvel at the thinking of scientists, but at the heterogeneous activity in which worlds are mobilised and without which thinking would lose all its strength. That is; it is not the logic, but the sociologics of abstractions which deserves our attention. For the reader who shifts from Latour's Science in Action to Foucault's The Order of Things, it is hard to conceive of a greater contrast. While it is true enough that Foucault also rejects the traditional history of thought, he does so for completely different reasons. Foucault does not reject the study of thought as such. But instead of a superficial history of opinions, he wishes to undertake an archaeology of knowledge: that is, a search for the underlying epistemes - general structures of thought - which made possible certain historical forms of scientific activity and debate. ${ }^{8}$

To be sure, in his analysis of natural history Foucault also refers to the establishment of gardens, herbaria and cabinets. But in his view, such collections were the result of a new way of connecting things, revealing a logic inherent to the episteme of the so-called classical age. In that classical period, extending from the seventeenth to the nineteenth century, gardens, herbaria and cabinets constituted a space in which things were juxtaposed, just like the words representing those things were juxtaposed and combined in a system of classification. When Foucault asks what made this juxtaposition possible, he does not refer to ships or methods of preservation, but to the underlying rules which were employed to define the objects of study, to form concepts and to build theories.

What made possible the juxtaposition of plants and animals in gardens, herbaria, cabinets and systems? ${ }^{9}$ For Foucault this is an all-important question, 
because he sees the table, a space in which creatures are spread out and present themselves one beside another, as a particular form of knowledge, as a way of ordering things which is not at all self-evident. It is a form of knowledge which was characteristic of an episteme which began to dominate Western thought only from the seventeenth century, and which was possible only as a result of a dissociation of words and things, of signs and resemblances.

Foucault points out that in the sixteenth century, before the emergence of classical thought, resemblances between things were conceived in terms of a complex of similitudes in which language and things were endlessly interwoven. Things were thought to be connected by many hidden similitudes - resemblances, affinities, sympathies - which, happily, were revealed by signatures engraved, so to speak, on the surface of things. How did one know that a walnut prevents internal head ailments? Because its appearance rendered visible an unexpected affinity with the human brain. Thus, to understand the world meant to decipher an endless network of signs, signs that were to be discovered, not only on things, but also in the Scriptures and Ancient texts with their hidden meanings. Nature and the word formed, as Foucault puts it, one vast single text. Language resided among plants, herbs, stones and animals, as much as in books.

How different was the relation between words and things in the classical age! Now, according to Foucault, things were supposed to show their resemblances to anyone who compared them and words were used to analyse that what was observed in terms of identity and difference. Words, that is, had been dissociated from things and classical thought filled the gap between the two by establishing a link between things on the one hand, and a system of signs and logical operations on the other. As Foucault emphasizes, it was only through such a system of signs and operations - the so-called mathesis - that things were dissociated and combined and so, appeared as distinct or identical. All this had an important consequence. Whereas in the Renaissance there had been a whole web of similitudes to be read from the things themselves, things, in the seventeenth and eighteenth century, were represented in a system of signs which constituted all empirical forms of knowledge as knowledge based upon identity and difference. Hence, the table as the centre of knowledge in the classical age.

Foucault, as we have seen, considers natural history as one of the empirical fields formed and defined by the classical episteme. It is true that before the seventeenth century all kinds of Histories of animals and plants had been written. But it was only from the seventeenth century onwards that Natural Histories appeared. In the traditional Histories, descriptions of animals or plants comprised all-embracing compilations of information on resemblances, virtues, the place in legends or heraldry, medicinal and culinary uses, written observations by the Ancients or travellers, etc. The history of a being was, as Foucault 
observes, the being immersed within a whole semantic network. Natural history, however, was another matter. On the one hand, there were animals and plants, stripped naked as it were. On the other hand, there was a system of signs which made it possible to see them and name them according to their identities and differences. So, from Foucault's point of view, Daubenton's statement in the Encyclopédie that the naturalist considers things only to compare them to other things, reveals the very structure of classical thought. ${ }^{10}$ Indeed, it was by juxtaposing animals and plants in gardens, herbaria and cabinets, and by representing them in systems of classification, that natural history found its place in the gap between words and things. Instead of signatures engraved on the surface of things, there were now plants and animals engraved in the substance of language!

\section{Representation: mind or means?}

When we confront Foucault's analysis of natural history with that of a Latourian observer, it is interesting to see that both Latour and Foucault emphasize the phenomenon of representation. Foucault, indeed, extensively discusses representation as a major feature of classical thought, indicating that where things and words happened to be separate, the distance between them had to be reduced through a representation. Natural history, then, was nothing more than "the nomination of the visible". But Foucault immediately points out that the visible was not simply imposed by the things themselves. It was a constituted visibility, created in an analysis in which much was left out: taste, smell, and above all, hearsay. It was a representation which was restricted to those few things that, in the words of Foucault, could be recognized by all and thus be given a name that everyone would be able to understand. Foucault also gives a detailed description of how such a representation was attained in the work of a Linneaus: that is, by the specification of four variables - number, form, proportion and situation - to be used in any description. Thus, according to Foucault, the confrontation of language and things could be established in a manner that excluded all uncertainty. But, that was not all. This very representation also linked the possibility of a natural history to the mathesis, to the system of signs and operations which made possible the establishment of a table in which all natural entities were ordered according to their identities and differences.

What else is Foucault explaining here than a meticulous way in which in natural history things were rendered mobile, stable and combinable? A Latourian observer might well be satisfied! However, it is clear that Foucault and Latour are discussing the activity of representation from radically different points of view. In the eyes of a Latourian observer, a translation of things into words is 
only one, clever step in an endless chain of activities in which the mobility, stability and combinability of things is progressively enhanced. Any disrupted link in that chain may put the possibility of a natural history to an end. When, on the other hand, Foucault asks what made natural history possible, he refers to a grand epistemological base, shimmering under the opinions and passions of naturalists. From this point of view, he likewise puts various, heterogeneous domains of activity on the same level - speaking, classifying, and exchanging but, what bound these activities together was a special feat of Western thought.

We may, however, push the confrontation somewhat further. True, for Latour, the Foucauldian translation of things into words (or any system of signs) is only one step in a chain of heterogeneous activities. But it is, in his view too, a crucial step. Yet even in the analysis of this one, crucial step, Latour and Foucault take completely different directions. In Foucault's view, the history of words and things is a history of sudden and enigmatic changes in the way things were conceived in the minds of men. One of the crucial events in this history is the way in which, from the seventeenth century onwards, the conception of things became linked to the logic of a mathesis. As a consequence, things were known - named - according to identities and differences, that is, in relation to each other, and not, as in the sixteenth century, each by themselves on the authority of marks engraved on them.

In the eyes of a Latourian observer, however, the history of words and things is not a history of conceptions. It is history of the means or tools through which statements, things and phenomena are tied together. That is, to understand the emergence of natural history as a science, we should focus on ships, on means of preservation and, not least, on the printing press. Indeed, Elizabeth Eisenstein has argued in a very suggestive and persuasive way that, far more than historians have acknowledged, the scientific revolution in Western Europe has been a result of what she calls the shift from script to print. ${ }^{11}$

It is very interesting to look again, but now from Eisenstein's point of view, at my account in chapter one of how in botany from the sixteenth century onwards attempts at classification began to take shape. ${ }^{12}$ That story begins with the herbals in the sixteenth century in which the historian finds early attempts to establish groupings of plants. Those herbals, to be sure, had a long history going back to antiquity. But as Eisenstein points out, it was a history that until the advent of printing at the end of the fifteenth century, could only be preserved in the form of written documents, locked up in a few libraries and copied from time to time through the work of scribes. As such, it was a very unstable history. Libraries could be destroyed, manuscripts could be lost or fragmented, scribes could err when copying a text. In this scribal culture, the history of compilations or catalogues like herbals was one of "increasing confusion and disorganization ${ }^{m .13}$ Moreover, to consult a substantial number of such texts a scholar had to 
be able and prepared to wander from one library to the next.

As Eisenstein shows, this situation began to change rapidly in the sixteenth century. Now many herbals, including classical texts derived from Greek authors, appeared in print and thus became available on a large scale for any scholar who wished to study and compare them, or to confront them with own observations. Although at first printed editions were often faithful copies of original manuscripts, such texts did not remain unaltered for long. With so many different readers, checking books against each other and against their own observations, and with printers eager to produce revised and enlarged editions, sixteenth-century herbals marked the beginning of a change that was contrary to the gradual deterioration which had tainted those works in the age of scribes.

Subsequent editions of printed herbals began to show a rapid accumulation of data, resulting from information and material received from readers or correspondents, but also from expeditions organized by printers, publishers or editors themselves, to get first hand information on the plants that were often so confusingly described in ancient books. Printing also made it possible to rely on pictures which, now that they could be reproduced without corruption, considerably relieved difficulties of identification. Indeed, as subsequent editions "became bigger, more crammed with data, and more profusely illustrated", it became evident that many plants had not been known to the Ancients, and it also became necessary to provide each work with "more tables, charts, indexes which made it possible for readers to retrieve the growing body of information that was stored". ${ }^{14}$

Eisenstein's work is all the more interesting because it contains some cues to a rather mundane explanation of the changing relation between words and things as described by Foucault. That is, according to Eisenstein, the products of printers were what "reshaped powers to manipulate objects, to perceive and think about varied phenomena". ${ }^{15}$ For example, the work of printers led to a standardization of texts, of type-styles and of illustrations, even to the point that sometimes the same engraving was used to designate many different cities, or many different historic personages. But, the result was also a fuller recognition of diversity: "the more standardized the image of typical town, head or plant, the more clearly the idiosyncratic features of separate towns, heads, or plants could be perceived by observant draughtsmen". ${ }^{16}$ Thus, here we might have a source of the heightened perception of identities and differences Foucault is talking about.

Still more interesting is that Eisenstein also relates the work of printers to a new "esprit de système". What came out from the printers" workshops was not only more and more books, but also catalogues and indexes which satisfied the need of readers and the commercial interests of printers as well. With the help of such catalogues, the Swiss scholar Conrad Gesner attempted, in the mid-sixteenth century, to produce a universal bibliography and a comprehensive refer- 
ence guide covering all Latin, Greek and Hebrew works published in print. In doing so, he also collected an "immense mass of information relating to the animal kingdom", leading to the publication of his famous seven-volume Historia Animalium. Thus, as Eisenstein puts it, "a long-lived desire to comprehend the divine scheme for creation and to classify and order all of God's creatures was given a new impetus". ${ }^{17}$ Indeed, as Eisenstein indicates, the ardour for system was not new, but before printing the memory was served, not by more and more systematic and comprehensive indexes available to every reader, but by esoteric symbolic systems and easy to memorize "vivid images", relating virtues to the imagery of flowers or names to the properties of things.

Eisenstein"s argument, then, clearly suggests how Foucault's dissociation of words and things might be a result of what happened when traditional forms of knowledge went to press. In the first age of printing, scholars were being flooded with an unprecedented turn out of ancient records presented in scrambled form which they believed to be fragments of some "vast Ur-book of Knowledge" ${ }^{18}$ Thus, in the eyes of Eisenstein, the so-called Renaissance thirst for synthesis, for seeing only resemblances, was not a new habit of mind, but an old passion that could be given freer rein by a sudden profusion of old texts. Now, a scholar like Gesner could really hope to gather together all that had been written on animals in ancient texts, to compare and collate these opinions with contemporary observations. Hence, Gesner's typical interest in the puzzles constituted by ancient names and words and their relation with known animal forms. Foucault's phrase that in the sixteenth century nature and the word formed one vast single text seems to be very apt indeed.

The confusion and puzzles embodied in the heritage of a scribal culture persisted, as Eisenstein points out, for at least a century and a half after the advent of printing. But, during the seventeenth century, when so many ancient texts had been scrutinized by so many different scholars, much of the original confusion began to fade away, as did much of the original fascination with the hidden meanings of symbols, words and names found in these texts. Moreover, with printed and authorized editions of bibles in different languages, plant forms were no longer needed for memorizing moral lessons. Places, plants and animals now appeared in the indexes of printed works in a much more neutral fashion. And, more importantly, with the possibilities of printing, words were being perceived as less reliable to describe things observed than hundreds of identical pictures. Thus it was that Fontenelle could note in 1733 that "the reign of words" had ended, and "things" were in demand." 19

Eisenstein's argument is of course highly relevant for a Latourian observer. Like Eisenstein, Latour wishes to shift attention from the mind to the practical means or tools which enable scientists to mobilize more and more resources. 
Moreover, as Latour emphasizes, among the variety of means or tools that may help seientists to mobilize resources, inscription devices are of crucial importance. It is through the translation of things into words and pictures on paper that things really can be mobilized on a grand scale. Hence, the enormous effects of the printing press which so decisively enhanced the mobility, stability and combinability of inscriptions. However, in Latour's view, the history of words and things is not the history of inscription per se, it is the history of what he calls a cascade of ever simplified inscriptions. ${ }^{20}$

What to do, for example, in a period in which voyages of exploration, the printing press, letter writing, as well as technical advances in illustration and preservation offered means to compile plants, animals, and all that had been said about them, on an unprecedented scale, filling sixteenth-century libraries with extremely massive encyclopaedic works which left a reader almost drowned in words and things? The answer according to Latour: inventing still more means! Hence, a Latourian observer will be highly interested in the hard and practical work of inventing means that allow a maximum of things to be translated into a minimum of words, like Linnaeus's search for a system that would allow him to reduce descriptions of genera and species to bare, essential definitions. ${ }^{21}$ From this perspective, the abstract form of a table will not suddenly appear as the centre of knowledge in a so-called classical age, but as an additional means in the ongoing and concrete work of abstraction.

\section{The strength of epistemology: Buffon}

In evaluating Latour's plea to focus on means instead of mind, we should not, however, forget the work of Linnaeus's famous adversary Buffon. What, after all, is more striking in Buffon's work than the special features of his theoretical and epistemological thought? Foucault, it is true, only mentions Buffon in his analysis of natural history to point out that he actually employed "the same grid" as Linnaeus. ${ }^{22}$ Yet, it is clear that the theoretical and epistemological foundations of Buffon's work differed from that of his fellow naturalists. Among historians of biology, this point has been emphasized especially by Phillip Sloan. Indeed, in his view, Buffon's epistemological concerns were of overriding importance. That is, according to Sloan, "Buffon's key importance in the history of Enlightenment biology is to be seen most generally in his attempt to give epistemological primacy to historical understanding". ${ }^{23}$ Thus, what we find in Buffon's work is "a consistent programme re-orienting natural history", whereby the critical innovation in his species concept was not so much the postulation of fertile interbreeding as an operational criterion of species identity, but rather the 
"metaphysical connection of organic species with the immanence of time". ${ }^{24}$

In fact, Sloan wants to make it clear that, to establish a historical interpretation of biological species, a particular epistemological position was required. According to Sloan, this was the reason why Buffon in the Histoire naturelle grounded his species concept on a particular distinction between "abstract" and "real" knowledge. In other words, in Buffon's work, epistemological considerations were a means to enhance the credibility of his concept of species. But was Buffon indeed successful in this respect? In general, the answer appears to be no. Thus, in a recent account of natural history in late eighteenth-century France, Corsi has observed that Buffon, despite the immense popularity of the Histoire naturelle, "did not succeed in converting many colleagues to his chemical, physical, taxonomic, and philosophical doctrines". ${ }^{25}$ And Sloan, too, indicates that Buffon's species concept, for all its sophistication, aroused but little interest among his fellow naturalists. ${ }^{26}$

Sloan also shows, however, that in "German biological circles" there were some interesting exceptions to this rule. The same point has been extensively discussed by Lenoir who points out that in Germany Buffon"s work became an important source of inspiration for the naturalists of the so-called Göttingen School. ${ }^{27}$ Just as Buffon sought to understand the relations between forms in terms of "internal moulds" which served as immutable types on which all individuals were being formed, the naturalists at Göttingen saw it as the goal of natural history to grasp the individuals encountered in experience under the hidden unity of some "Urform". Both Sloan and Lenoir emphasize moreover that Buffon's epistemological concerns were brought to the attention of naturalists in a much more elaborated form through the work of Immanuel Kant. Sloan and Lenoir, each in their own way, claim that the reception of Buffon's ideas among German naturalists critically depended on Kant's epistemological justification of these ideas. So, Lenoir observes that in Germany everyone agreed that "the philosophy of nature must be consistent with ... Kant's critique of scientific knowledge" and that Kant"s work thus "was strong endorsement for the research program of the Göttingen School". ${ }^{28}$ Sloan too, emphasizes the crucial role of epistemological concerns, even when explaining why many German naturalists did not wholeheartedly accept Buffon's or Kant's natural history. In his view, these naturalists simply "failed to comprehend" the epistemological foundation of Buffon's or Kant's argument. ${ }^{29}$

However, the evidence in the articles of Sloan and Lenoir clearly suggests that there were also other, more mundane considerations by which naturalists were guided in their reactions to Buffon's or Kant's work. The principal question that was raised by Buffon's work was this: if a natural system of classification depends on knowledge of permanent types from which all organic forms have originated in the 
course of time, how to trace these types among the great variety of beings? Buffon, as we have seen, sought to establish the natural unity of species on the basis of the criterion of interbreeding. In Germany, Kant explicitly adhered to Buffon's approach when he discussed the taxonomic status of man in his writings on natural history. Those taxonomists who had split mankind into different species on the basis of morphological characteristics, had failed to see, in his view, that the interfertility of different races proved their origin from one and the same stem. ${ }^{30}$

Kant indeed justified his views in terms of his emerging epistemology which led him to distinguish between a logical "description" and a genealogical "history" of nature, whereby the latter had to be the basis of a natural system of classification. ${ }^{31}$ But it is significant that Kant's position was sharply criticized by the prominent German naturalist Johann Georg A. Foster. Foster, as Sloan points out, first of all criticized Kant for his belief that an empirical issue could be resolved by purely philosophical and epistemological considerations. Moreover, in Foster's view:

the history of nature might indeed be a science for gods alone, and not for men: who is capable of demonstrating the genealogical tree of so much as one single variety up to its genus, if it does not arise from another nearly in front of our eyes? $?^{32}$

Forster was not alone in this critique. On the contrary, according to Sloan, most German naturalists adhered to a belief "that the key to the natural system was intimately connected with morphological characters". ${ }^{33}$ What is still more important, however, is that for a naturalist like Forster the question obviously was not whether there were epistemological means to justify a genealogical or historical species concept, but whether there were practical, material means to tum such a concept into an indisputable fact. Naturalists, in fact, generally agreed that species might be considered as groups of individuals that are related by a generational bond. ${ }^{34}$ But how to make such a bond visible? Was fertile interbreeding indeed an operational criterion of species identity? It was not; and nothing was more revealing in this respect than Buffon's own Histoire naturelle. We have seen that Buffon, in carrying out his programme, was simply unable to establish, in the vast majority of cases, to what extent interbreeding occurred or could be achieved. That is, in attempting to establish species or more comprehensive, "physical" genera he could not help relying also on morphological characteristics, sometimes, as in the case of the dog and the wolf, uniting species on the basis of striking resemblances even when these species manifestly did not reproduce together. It need not surprise us then that Buffon's interbreeding criterion was considered by some to have been refuted by Buffon himself. ${ }^{35}$ 
Aithough authors like Sloan and Lenoir seek to understand the fate of Buffon"s concept of species by focusing almost exclusively on the way in which this concept was tied to epistemological considerations, there is, in fact, little indication in their accounts that such considerations really had much strength in the eyes of naturalists themselves. Buffon's work obviously was judged by naturalists on other than purely epistemological grounds. ${ }^{36}$ In this respect, the influential German naturalist Johann Blumenbach is a most interesting example. He was one of those Göttingen naturalists who was inspired by Buffon's concept of an "interior mould" and who was well acquainted with Kant's writings on natural history. Yet, he too, as both Sloan and Lenoir point out, did not accept the interbreeding definition of species, especially because it was an impractical criterion in his view. He regarded the question whether two different forms belonged to the same species as one that in practice could only be answered through anatomical investigations. ${ }^{37}$ So, even in understanding the fate of Buffon's highly "theory-laden" concept of species, it seems appropriate to shift our attention from mind to means. Indeed, as we will see in the next part, what really strengthened the belief in the possibility of a true, natural system of classification was not Buffon's or Kant's epistemological considerations, but the techniques of comparative anatomy which Cuvier introduced at the end of the eighteenth century. 38

\section{Conclusion}

What is especially interesting about a confrontation between a Latourian and Foucauldian account of natural history is that, on the one hand, in both accounts the analysis is focused on the emergence of a framework which made it possible freely to go from one plant or animal to another, whereas on the other hand, the emergence of that framework is traced in completely different ways. In the eyes of a Latourian observer, such a framework emerged as a result of "lowly work", that is, of a variety of heterogeneous activities - collecting, preserving, describing, drawing, comparing - whereby the results of these activities were rendered equivalent by tying them to "metrological" procedures: the use of particular methods of preservation, of standardized ways of description and name-giving, of a fixed number of taxonomic categories, etc. ${ }^{39}$ For Foucault, however, the juxtaposition of plants and animals in a system of classification was made possible by rules embodied in the "table" that emerged with the advent of a classical episteme, that is, with the advent of a particular form of thought.

Here then we have the point everything hinges on: whereas for Latour the abstractions of naturalists can be fully understood through a study of the concrete means by which they are produced, it is, according to Foucault, necessary 
to understand the general features of thought underlying the daily pursuits of men. Why is Latour so persistent in his emphasis on the concrete work of making abstractions? Because, as he writes in Science in Action, this work is fully studiable, which is not the case if it becomes something mysterious going on in the mind. And indeed, it must be admitted that in Foucault's analysis the features of natural history often remain somewhat enigmatic just because they are related to inherent qualities of thought.

Why, for example, were plants and animals classified only on the basis of easily visible, external characteristics? Foucault points out that beings were only able to enter into the sequence of a descriptive language and so, into the field of a mathesis, within the "area of the visible", of "surfaces and lines". If, however, we accept Latour's point of view and first study the means by which things were rendered mobile, stable and combinable, then we will see that, especially in zoology, the surface of things was much more easily rendered mobile and stable than their interior parts. That is, shells, skins, teeth and nails were much more easily collected and preserved than molluscs or intestines. In his analysis of natural history, Foucault further points out that natural objects which in reality were found dispersed in space and time, were arranged into a table detached from real space and time. In his view, it is inherent in classical thought that a "continuity of juxtaposition" is put in the place of the discontinuity of being in space and time. Latour, in his turn, would emphasize that any enhancement of the mobility, stability and combinability of things, puts scientists in the position to reduce space and time to a scale that can be dominated by sight. That is, any step in which things are rendered mobile, stable and combinable, implies the creation of a different space-time.

So far, it is clear that Foucault's intriguing attempt to interpret natural history as the manifestation of a logic inherent in a particular and comprehensive episteme, cannot withstand the force of a true, Latourian sociologics. As we have seen, Latour states as one of his rules of method that we should always first look at how observers move in space and time, how the mobility, stability and combinability of inscriptions are enhanced, how the networks are extended, how all the information is tied together in a cascade of re-representation, and only then, if there is something unaccounted for, may we look for special cognitive abilities. It hardly needs saying that Latour does not seriously believe that such a move ever will be needed. ${ }^{40}$

Should we accept Latour's methodological dictum and simply stop our confrontation here? The answer is no. In the foregoing, I have confronted Foucault with Latour only insofar as both were talking about a common subject, that is, the activity of representation. In The Order of Things, however, the subject-matter is not so much the activity of representation, but the appearance of discontinuities. In Foucault's words, the problem under discussion is the fact 
that within the space of a few years "a culture sometimes ceases to think as it had been thinking up till then and begins to think other things in a new way". ${ }^{41}$ As a first step towards an understanding of such discontinuities, Foucault has set himself the task to establish an archaeology which has to deal, not with the activities in which thought takes shape, but with the radically different forms that have succeeded each other in the history of thought.

It is true that in the foregoing I have discussed the work of Eisenstein to show how a shift from mind to means may help us to understand Foucauldian changes in forms of thought. But, interesting as that may be, it's certainly not the whole story. Even if we follow Latour in his admiration for the means through which naturalists managed to dominate at a glance a growing number of plants and animals from all parts of the world, it cannot be denied that the search for system also suggests the importance of something else. When plants and animals have been collected from distant places, have been grown, dried, stuffed or preserved in alcohol, have been painted and described, a naturalist still will be faced with the problem of how to compare and classify everything amassed. Which characteristics have to be considered in the comparison of forms and how is their relative value in attempts at classification to be assessed? These were burning questions in the eyes of seventeenth and eighteenth-century naturalists, and accordingly, historians of biology have amply discussed the different ways in which naturalists have answered these questions.

Indeed, as we will see in the next part, even with the rise of Linnaean taxonomy the battle of systems did not end. Especially in zoology, the Linnaean approach to classification was severely criticized by those naturalists who aspired to a truly natural system. In fact, authors on the history of biology often see the end of the eighteenth century as a turning-point in the history of classification because it was then that naturalists really began to see how such a natural system might be achieved. Foucault even goes a step further. In his view, natural history not only emerged half-way through the seventeenth century as a result of a radical transformation of the then prevalent forms of thought, it also made way for a biology at the end of the eighteenth century as a result of another, no less radical change of thought.

Whereas for Foucault the development of natural history in the eighteenth century is a history interrupted by a radical discontinuity in the way in which relations between plants or animals were conceived, for a Latourian observer it is a history of networks that are continually extended. However, as I will show in the next part, it is perfectly possible to understand those discontinuities in naturalists's conceptions of the world as the result of continual attempts to extend networks of statements, things and phenomena. But to pursue this point, we first have to go back to natural history to see what happened to it at the end of the eighteenth century. 


\section{References}

1. An exception is perhaps Edward Lee Greene's Landmarks of Botanical History. For a general account of the reception of Linnaeus's work see Stafleu, 1971.

2. My account of a Latourian view of natural history is based on chapter 6 of Science in Action. Latour discusses natural history as an example on pp. 225 and 229.

3. Chapter I, p. 24.

4. Ibid., pp. 35-36.

5. In his discussion of Brisson's work, Farber observes that "Brisson's careful descriptions and Martinet's illustrations of Réaumur's collection have preserved the knowledge of this collection well after most of the original specimens have disappeared, and he adds that "unfortunately, many contemporary collections ... sank into decay before any careful record was made". See Farber, 1982a, p. 162 (note 5).

6. Chapter I, p. 23.

7. Chapter II, p. 64. See also Daubenton's lament in the Encyclopédie quoted in chapter I, p. 28.

8. See also my discussion of Foucault's work in the Introduction.

9. The following account of Foucault's work is based on the chapters 2,3 and 5 of The Order of Things.

10. Chapter I, p. 23.

11. Eisenstein, 1979: My account of Eisenstein's argument is principally based on chapters 2, 3 and 5. See also Latour, 1986, pp. 11-14.

12. See especially the first paragraph of the section on problems of botanical classification, Chapter I, p. 29.

13. Eisenstein, 1979, p 108.

14. Ibid., p. 109.

15. Ibid., p. 88.

16. Ibid., p. 86 .

17. Ibid., p. 99. For a more elaborate account of Gesner's work in natural history and the means through which it was created, see Rudwick, 1976, chapter 1.

18. Ibid., p. 279.

19. Ibild., p. 698.

20. Latour, 1986, pp. 14-20.

21. See especially the section on the genus as a keystone, Chapter II, pp. 53-54.

22. Foucault, 1970a, p. 135.

23. Sloan, 1979, p. 111. See also Sloan, 1976; and the introduction in Lyon and Sloan, 1981.

24. Ibid., pp. 121 and 117-118.

25. Corsi, 1988 , chapter 1 , p. 1 . 
26. These evaluations are at complete variance with Farber's opinion that Buffon's species concept "had an immense impact on the biology of his day". Farber, however, substantiates his point only in the most general terms, referring to the general popularity of the Histoine naturelle and to the way in which Buffon's concept of species reflected the theoretical biases of the age" (and those of the French philosophes in particular). See Farber, 1972, especially pp. 282-284. In his study of the reception of the Histoire naturelle in Scotland, Wood also concludes that Buffon"s theoretical ideas were generally rejected. See Wood, 1987.

27. Lenoir, 1981.

28. Ibid., pp. $154-155$.

29. See for example Sloan, 1979, p. 123.

30. Ibid, p. 131.

31. See the articles of Sloan and Lenoir for more detailed accounts of Kant's early position.

32. Quoted by Sloan from Forster's "Noch etwas uber Menschenrassen". Sloan, 1979, p. 132 .

33. Ibid., p. 122.

34. As we have seen such a definition of species was adopted by Ray as well as by Linnaeus. See chapter II, pp 50 and 67.

35. Sloan, 1979, pp. 124-125. According to Sloan, German naturalists generally saw "a rising tide of evidence against the interbreeding criterion", p. 130.

36. Sloan is rather ambiguous on this point. Although he continuously suggests that epistemological considerations (or a failure to understand them) were decisive in the development and reception of Buffon's species concept, he concludes his article with saying that a historical and genealogical approach to taxonomy was abandoned by many naturalists "for practical and even epistemological reasons". Ibid., p. 145 (italics mine).

37. Ibid., p. 137. See also Lenoir, 1981, pp. 129-132. In France, the young naturalist Cuvier was another example. Although, in Cuvier's opinion, successful interbreeding was decisive in the definition of species, it was also evident to him that in general interbreeding was impossible to demonstrate and, according to Coleman "it is perhaps for this reason that he (Cuvier) added a morphological clause to his species definition". Coleman, 1964, pp. 144-145.

38. See for the impact of Cuvier's "powerful new methods" on the work of German naturalists: Lenoir, 1982, pp. 54-65. See also Corsi, 1988, pp. 236-239.

39. For the notion of "metrology" see Latour, $1987, \mathrm{pp}, 247-257$; and especially Latour, 1988. For an interesting discussion of the role of such metrological procedures in natural history see also Star and Griesemer, 1989.

40. Latour, 1987, pp. 246-247.

41. Foucault, 1970 a, p. 50 . 
PART II 



\section{NATURAL HISTORY TRANSFORMED}

\section{French pleas for reform}

When we look at how eighteenth-century naturalists were tying together plants or animals in systems of classification, it becomes immediately clear that there was more involved than just the creation of abstractions. Indeed, the meaning of those abstractions was the subject of a lasting and occasionally heated debate. How to conceive of a system? Could it be regarded as merely a convenient method for memorizing plants or animals, or had it somehow to represent the order in nature? Opinions on this point varied. Linnaeus emphatically distinguished artificial systems of classification from a true natural method. In his view, the natural method was a goal to be attained, but not at short notice. So, Linnaeus's aim was a system that would be as natural as possible. Many naturalists eagerly accepted Linnaeus's work because of his uniform and concise definitions of genera and species. At the same time however, the foundations of his system were often criticised, notably in France. ${ }^{1}$ According to these critics, the relations among the multiplicity of beings were too numerous and subtle to be caught in a system based on only a few arbitrarily chosen parts. In their view, one might hope to achieve a true, natural system of classification only by taking into account all parts of a plant or animal.

In France, Buffon was of course a most passionate critic of "petty" systems. But the ideal of a natural method became especially related to the names of two other French naturalists who turned this ideal into practice without following Buffon in his radical rejection of any system whatsoever. In botany, at the end of the eighteenth century Antoine-Laurent de Jussieu introduced his famous method for "calculating" the relative value of characteristics which allowed him to create a system that would not violate the natural affinities of plants. This work then inspired the young naturalist Georges Cuvier to start his own long-standing and much celebrated search for a natural system in zoology.

It is often suggested, however, that what happened in natural history at the end of the eighteenth century was more than just the creation of some new methods of classification. That is, authors on the history of biology often refer to the end of the eighteenth century as a period in which natural history was 
transformed into a "history of nature", or into a "biology" as a true science of life. ${ }^{2}$ This idea of a transformation of natural history has been voiced, no doubt, most pregnantly in Foucault's The Order of Things. However, before discussing Foucault's ideas, I will first present a more detailed historical account of what happened to natural history at the end of the eighteenth century in the eyes of historians of biology. In so doing, I have allowed myself a limitation. That is, in the second part of this book, I do not discuss natural history in general, but I will focus on zoology and in particular on its development in France.

As we will see, in the early nineteenth century Paris became an outstanding centre of research in natural history, a centre that became especially famous through the studies of animal form initiated by Cuvier. In the analysis of Foucault, Cuvier's work is indeed the prime example of a particular concern with life that; according to Foucault, characterized the end of natural history and the beginning of biology. In the next chapter I will discuss Cuvier's work in detail, together with that of Geoffroy Saint-Hilaire who also played an important role in the shaping of abstractions in early nineteenth-century zoology. But it would be wrong, of course, to consider the work of naturalists like Cuvier and Geoffroy as an isolated achievement. In fact, in many respects their work reflected what Corsi has described as a debate on the reform of natural history in late eighteenth-century France. ${ }^{3}$

It is this "debate" which I will discuss in the present chapter, taking as a starting-point an early publication of Geoffroy and Cuvier in which they propose a new way to classify the Linnaean class of Marnmals. From a Latourian perspective, we may regard this article as a nodal point in a network of statements, things and phenomena. Thus, from this perspective, the article obviously will not appear as something which suddenly sprang from the mind of scientists who in retrospect have transformed the science of natural history, but as something which represents a great number of heterogeneous activities in which others have rendered things mobile, stable and combinable. As such the article may be considered as the tip of an iceberg, and what I will attempt in this chapter is to trace all the heterogeneous elements which have been represented in the abstractions of which the article is composed. Nonetheless, in their article Geoffroy and Cuvier not only represented many elements, but they also added something new. What they did we may see as a proposal to relate a variety of statements, things and phenomena in a new way. In other words, the characteristic feature of their work is not so much the extension of a network, but rather its transformation. Indeed, as we will see in chapter six, it is this very transformation which, according to Foucault, deserves particular attention. 


\section{A new classification}

The young Parisian naturalists, Etienne Geoffroy Saint-Hilaire and Georges Cuvier, were at the very beginning of their careers when; in 1795 , they published a memoir in which they proposed a general revision of the Mammals, the class of animals that Linnaeus had introduced in 1758 in the tenth edition of his Systema Naturae. ${ }^{4}$ It was their intention, as they said, to arrange the Mammals:

... en ordre et en genres aussi naturels que peuvent l'être les agrégations qui, malgré tout le soin qu'on met à les former, n'ont toujours pour base que les abstractions des naturalistes...

Thus, any order and any genus will always be an abstraction of naturalists, but, as Geoffroy and Cuvier pointed out, those abstractions surely have their foundations in nature. Different species often show similar combinations of organs and thus may be united on the basis of such overall resemblances. However, in doing so, naturalists have sought to relieve the memory by representing those multiple relationships through a most salient, or what is called, essential characteristic. Moreover, naturalists have sought to represent all genera in such a way that they could be easily compared and, to that end, have been prone to take characteristics only from one and the same part. In the view of the authors:

... cette idée, bonne en elle même, est ce qui a fait pendant longtemps de l'Histoire naturelle une sorte d'art pueril qui ne consistoit qu'à caser les espèces, d'après des règles, variables au gré de chaque auteur, et ayant la plupart aussi peu de rapport avec l'ordre de la nature, que les places qu'occupent les noms d'hommes dans les dictionnaires historiques en ont avec l'ordre de la chronologie.

As to the parts from which the characteristics indicating genera, orders and classes have been taken, the authors observed that they are arbitrarily chosen, without regard to the value and constancy of the characteristics seized upon. Zoologists obviously did not have the slightest notion of that calculation of characteristics which by now was generally acknowledged in botany. Zoologists, then, would do well to revert to the principle of Linnaeus, which says that characteristics must not determine genera, but genera must indicate characteristics. That principle, which in practice Linnaeus seemed sometimes to have forgotten, must be applied to orders and classes as well. Of course, it might appear that it is impossible to find characteristics neatly indicating natural groups, but the authors announced that: 
... nous sommes loin d'admettre cette impossibilité; le but de notre mémoire est au contraire d'indiquer par quelles voles on peut parvenir aे former des coupures naturelles, et néanmoins, à leur assigner des caractères fixes et déterminés; à réunir en un mot les avantages de l'ordre naturel et ceux de la dichotomie, qui fait toujours la base implicite ou développée de tout système artificiel.

Which ways were open to the achievement of such a goal? Geoffroy and Cuvier first of all presupposed that naturalists knew the totality of natural relationships in the animal world. So, the principal question to be answered was which characteristics would correctly indicate those relationships. In the view of the authors, the answer to that question depended on knowledge of the relative value of characteristics; that is, those characteristics will be most important which are taken from the most important organs. In fact:

... on conçoit que dans un système aussi bien lié que l'économie animale, il est des organes dont la conformité entraîne nécessairement celle de la plupart des autres, et qu'on doit pouvoir les déterminer par le raisonnement et par l'expérience.

Here we have the solution proposed by the authors. Characteristics taken from those organs which involve the conformation of most others, will at the same time most effectively indicate the majority of relationships and, thus, the natural divisions in the animal world. Now that the solution was given in principle, Geoffroy and Cuvier proceeded to show how it would work out in practice. They argued that an animal first of all exists and in virtue of that existence acts and has sensations. The existence of an animal first of all depends on the generation and then on the circulation. Thus, organs of generation and circulation will supply characteristics of the first degree. Hence, the Mammals result from a first division of the animal world, whereas other classes of animals are based on characteristics taken from organs of the circulation. Divisions which indeed, as the authors indicated, for the most part concurred with those of Linnaeus.

How then to subdivide the class which was the principal subject of Geoffroy and Cuvier: the Mammals? One now had to invoke characteristics of the second degree, that is, those taken from the organs through which animals act and have sensations. Animals act to save themselves from danger and to feed. However, it is the mode of feeding that determines the appropriate organs in the most constant manner. A camivorous animal, for example, must have the means to attack and conquer a prey, whereas animals living from fruit must be able to climb trees, etc. Regarding the sensations of animals, the authors observed that it is, without any 
doubt, the sense of touch which is the most important. Can one imagine a greater distance between the touch of a horse, with its rigid and insensible hoofs, and that of an ape or squirrel, with hands that are almost as perfect as ours? Moreover, the organs of touch lend themselves to divisions, more numerous, more salient, and more rigorous than all the other sense-organs put together.

Thus, the Mammals may be subdivided on the basis of characteristics taken from the organs of nutrition and of touch. In principle, the authors considered both to be equally important. However, they also argued that the organs of nutrition are internal as well as external and that, although both are relevant for the establishment of natural divisions, characteristics indicating these divisions must by necessity be taken from the latter. Of course, external and internal characteristics are strongly related to each other. The absence of canines, for example, always goes together with a simple stomach and an enormous appendix. But that does not alter the fact that, if one can refer only to teeth in practice, one is invoking only one small element of the organs of nutrition as a whole. Hence, these characteristics must be relegated to the third degree. Moreover, one may prove this judgement by following the example of botanists, that is, by calculating the relative constancy of characteristics. Then, it appears that characteristics taken from the organs of touch are indeed the most constant in those orders of animals which are evidently natural. So, the authors triumphantly concluded:

Voilà done le rang de ces caractères décidé. Les téguments des doigts vont avant les dents. Ce principe une fois posé, notre marche est devenue sûre, et vous allez voir avec quelle facilité nous en avons déduit des ordres aussi naturels qu'aisés à désigner par des caractères tranchés qui ne souffrent point d'exeptions.

\section{In search of a natural method}

I have discussed Geoffroy and Cuvier's memoir at such length, because it provides us with a very revealing picture of the problems of classification as they were conceived by French naturalists at the end of the eighteenth century. To begin with, it is clear that although the authors were very critical of the work of Linnaeus, they accepted it in several respects. It was Linnaeus, for example, who had introduced the Mammals as a class, and had thus discarded the wellknown Quadrupeds. But more revealing than the content of their classification, is the way the authors defined their problem. Their problem was not that rigorous classification was impossible, as it had been for Buffon. Their problem was how to reconcile this practice of classification with the real divisions of nature. 
In short, their ambition was to achieve a natural method. For Linnaeus, too, that had been the ultimate goal, but more than once he had thought it necessary to sacrifice this goal to the exigencies of a system. Geoffroy and Cuvier now apparently believed that a natural method was a realistic possibility, and in that opinion they were certainly not alone. Indeed, botanists, especially those in Paris, had already been pondering a natural method for some considerable time.

As we have seen, Bernard de Jussieu, who worked from 1722 to 1777 as demonstrator of plants at the Jardin du Roy and whose opinions were held in high esteem, had pronounced as early as 1739 that he preferred the Linnaean method to that of Tournefort. ${ }^{5}$ But, in fact, de Jussieu accepted neither Linnaeus's sexual system, nor his generic reform. What did appeal to him in Linnaeus's work were the "fragments of a natural method", which had been added to the Parisian edition of the Genera Plantarum of $1743^{6}$ It was the search for such a natural method that preoccupied de Jussieu as well as several of his pupils, including Michel Adanson and Antoine-Laurent de Jussieu (a nephew of Bernard).

Adanson's commitment to a so-called natural method originated from his stay in Senegal from 1748 to $1754 .^{7}$ There he had been studying the regional flora and fauna, trying to assimilate his observations to the systems of Tournefort and Linnaeus. However, his hopes were completely disappointed and, back again in Paris, he observed that:

Une recherche très pénible et souvent infructueuse, pour rapporter les plantes du Sénégal aux genres connus, m'a appris, par une perte de temps considérable, qu'il n'y a presque aucun fonds à faire sur les genres étrangers publiés par M. Linnaeus d'après l'anatomie des fleurs desséchées ou d'après les figures et descriptions des voyageurs même les plus instruits. ${ }^{8}$

Adanson concluded that systems in which plants were arranged according to characteristics taken from one or two parts were much too limited and could never accomodate the experiences of a naturalist who left the climatic zone of his own country. In his view it was necessary to take all parts into account and thus to arrange plants into natural "families" which, on the basis of their multiple resemblances, often appeared to shade into each other, thus forming what Adanson believed to be a continuous chain. ${ }^{9}$

A natural method was also the aim of Antoine-Laurent de Jussieu, who started teaching botany at the Jardin du Roy in 1770. Like Adanson, de Jussieu conceived of the variety of plant forms as a continuous series. However, an arrangement of plants into a continuous chain of natural groups, based on a complete knowledge of all parts, obviously did not satisfy the need for easy identification of genera and species, a need which was clearly felt at the Jardin because 
of instruction purposes. So de Jussieu undertook the task of devising a method according to which natural groups of plants could be rigorously defined. ${ }^{10}$ In his view, Linnaeus's work might be accepted on the level of species and genera, but it failed as far as orders and classes were concerned:

I deviate from that great man in his systematics, which seem to keep science away from its true goal, but I hold in high esteem his nomenclature, his genera, his species; and I believe he has rendered a real service to botany in this respect ...

But which characteristics could be found for definitions of orders and classes that would be fixed and rigorous and yet would conform to the multiple affinities of plants? De Jussieu sought to answer that question in part through an exact ranking of characteristics according to their observed constancy in those groups of plants which were generally accepted as natural on the basis of overall resemblances. It was this method to which Geoffroy and Cuvier referred as the calculation of characteristics, in which those characteristics which appeared to be most constant, individually as well as in their mutual relationships; were assigned a preponderant role in the creation of a natural system of classification. ${ }^{12}$

Thus, it is clear that in Paris Buffon was not alone in his eloquent opposition to Linnaeus. After his Senegalese voyage Adanson joined him as an enemy of abstract systems. De Jussieu, it is true, accepted Linnaeus's work as far as it reconciled the establishment of natural groups with exact definitions, but he also made it clear that in this respect Linnaeus's system was found wanting. On the other hand, Lamarck, another Parisian naturalist, rejected Linnaeus's system for the very reason that it confused the need for system with the representation of real relationships. In 1778, with the support of Buffon, he published a Flore française with a genuinely artificial system, serving only for the rapid identification of plants and thus to be clearly distinguished from the real plan of nature, a plan which Lamarck conceived as a continuous chain of forms with decreasing modes of organization. ${ }^{13}$

Obviously, each of these reactions in its own way revealed the tension which was so often felt by naturalists between a conception of overall affinity and continuity among forms on the one hand and a need for system on the other. But however different their reactions to this tension may have been, for all these Parisian naturalists the search for a natural method clearly was the only scientifically legitimate goal. Most of them considered Linnaeus's nomenclature useful and his "fragments" of a natural method stimulating, but all agreed that his system was incompatible with the "true goal" of science. 


\section{Linnaeans win ground}

Reservations in the French capital notwithstanding, systems were seen by many naturalists as an indispensable means for the organization of their work, whatever the imperfections. In fact, as Daudin points out, Buffon's zeal for showing the triviality of the Linnaean system demonstrated that Linnaeus's work was already too important to be ignored. ${ }^{14}$ The rules proposed by Linnaeus for description and nomenclature were accepted by a growing number of naturalists as standards in terms of which they could understand and assess each other's work and could contribute to the establishment of genera and species. ${ }^{15}$ His system also stimulated many to identify and study plants in the field, which led Jean-Jacques Rousseau to glorify the Linnean system for its didactic virtues. ${ }^{16}$ However, it was at first mainly in provincial France that naturalists accepted and began to use the Linnaean system and nomenclature. Montpellier, for example, became a stronghold for Linnaean research thanks to the efforts of Antoine Gouan, a medical professor who in 1768 published the first regional flora in Linnaean style and who had many pupils. ${ }^{17}$

Later, several of Gouan's pupils went to Paris and it was one of them who, in 1788 , took the initiative to found a "Société Linnéenne" which was formed so that naturalists might exchange Latin descriptions of species, written "according to the rules of Linnaeus and accompanied by exact drawings". ${ }^{18}$ There were thirty members, including Daubenton and Lamarck, but the society was granted a short life only. The initiative evidently found no favour in the eyes of authorities like Buffon and de Jussieu. Probably on the latter's instigation, it was soon put about that anyone who hoped for election to the Académie des Sciences would do well to leave the Société Linnéenne. As a consequence, the society collapsed before it had really started, to be revived again two years later, but under very different circumstances. ${ }^{19}$ Buffon died in 1788 and, more importantly, power relations in the French capital changed drastically. One of the changes in the early years of the Revolution was the emerging resentment against science and its prestigious institutions. ${ }^{20}$ Science, especially the mathematical spirit of Newtonian science, was charged with being alienated from man and his moral and practical affairs. The new chemistry, in particular the nomenclature introduced by Lavoisier and others, was attacked as an injury to honest craftsmen. But natural history was another matter. What else could it be than a genuine manifestation of the love of nature, in which everybody could take part?

Thus, under changed circumstances the aborted Société Linnéenne was reconstituted in 1790 under the name "Société d'Histoire naturelle". The new society attracted almost all Parisian naturalists, entered into relations with popular societies of inventors, artisans, and artists and also recruited new members 
"of whom no qualifications were required beyond a love of nature" ${ }^{21}$ The society further showed its undiminished respect for Linnaeus by placing a bust of the great systematist in the middle of the Jardin. It planned the preparation of a general and systematical catalogue in which all objects would be arranged according to the system of Linnaeus (with the exception of the minerals). Courses were instituted by some of the more specialist members of the society. Moreover, the society wished to foster the study of plants and animals from exotic regions and for the sake of that study it joined with, or initiated itself, foreign expeditions or otherwise obtained materials collected from areas still unknown. For those naturalists abroad who in their descriptions remained indifferent to any method, or still preferred popular names to the Linnaean nomenclature, special recommendations were drafted on how to communicate their observations so that these would allow of a methodical interpretation. ${ }^{22}$

\section{Hallmarks of science}

The Société d"Histoire naturelle clearly marked and reinforced the attempts of French naturalists to organize instruction and research in Linnaean style. Yet what was involved in this enthusiasm by no means corresponded to the uncomplicated love of nature or the desire for utility by which the Society was justified in the revolutionary years. For most naturalists, the appeal of Linnaeus's work rested on the distinctness and exactness of its definitions, an exactness which was deemed necessary for a real advancement of science. Indeed, the new chemical nomenclature, proposed in 1787 by Lavoisier and others, was regarded by many as the outstanding example of what could be achieved by rigorous classification. Naturalists might even have seen it, as Corsi suggests, as a severe blow against Buffon and his followers. ${ }^{23} \mathrm{So}$, it was the work of Lavoisier that, for all its purported elitist qualities, raised hopes with those naturalists who emphasized the importance of exact classification and nomenclature. Moreover, Lavoisier's work was not the only recent development in the world of science that was enthusiastically debated by French naturalists. Conducive to such debates were the new societies that had been founded during the years of the revolution and which recruited members of various vocations. In Paris, the Société d'Histoire naturelle was only one among several others. Especially well-known was the Sociéte Philomatique which altracted many members with a general interest in the sciences and which published a bulletin with articles discussing the latest developments in physics, chemistry and crystallography. ${ }^{24}$

Crystallography, an old branch of natural history, was indeed one of the fields that aroused great interest at the end of the eighteenth century. ${ }^{25}$ In 1784 at Paris, the 
Abbe Haily had published a theory on crystal structure which he then developed into a new approach to the classification of crystals. According to his theory, the multitude of crystal shapes were all varieties of some geometrically defined, basic crystal structures. Instead of classifying crystals on the basis of external characteristics, Hauly now wished to convert crystallography to a science by arranging crystals according to the geometrical characteristics of their constituent basic structures. Naturalists, then, had to describe crystals by a nomenclature concisely expressing the mathematical laws rellating basic forms to secondary shapes. According to Corsi, Haily's work was welcomed by several Parisian naturalists as another successful attempt to confer logical and mathematical rigour upon the practice of classification. However, Corsi also points out that this ideal of scientific progress was not shared by all. Daubenton, Buffon's former collaborator, criticized Haüy's work, warning in terms by now familiar that:

il faut se rappeler que tous les objets qui sont placés dans des méthodes, au dessus et au dessous de l'espèce, ne suivent que des règles arbitraires auquelles la nature met beaucoup d'exceptions. ${ }^{26}$

But Daubenton did not leave it at that. He also criticized the use of words of Greek origin in mineral classifications, showing in his comments that he had well understood the spirit of the age:

Il faut tâcher de trouver des noms dans sa propre langue: on doit travailler pour ses compatriotes, sur-tout lorsque la nation dont est membre, favorise le progrès de la science, et indemnise les professeurs pour l'instruction publique. Si l'on est obligé d'employer des noms qui ne soient entendus que par les savans, on nuit au plus grand nombre des gens de son pays. ${ }^{27}$

Daubenton's opposition was, however, no more than a rearguard action. Many if not most Parisian naturalists undoubtedly saw the achievements in chemistry and crystallography as hallmarks of science. Many of them also came to believe that Linnaeus's work contained the principles that could make natural history into a veritable science as well. But even for those who eagerly accepted those principles, it was seldom a matter of outright glorification of the Linnaean system. Linnaeus's work, that is, was by no means perceived as definitive and the question how to proceed remained an important subject of debate. ${ }^{28}$ Geoffroy and Cuvier's memoir, with which this chapter opened, perfectly illustrates this state of affairs. It was read before the Sociéte d'Histoire naturelle at the time that Linnaeus's zoological classifications had inspired several naturalists to reflect upon a more natural method for the classification of animals. ${ }^{29}$ 


\section{The significance of characteristics}

In the foregoing chapters I have already indicated how, especially in zoology, the practice of classification was dominated by naturalists in cabinets and libraries and how these circumstances were reflected by the systems of zoological classification, including that of Linnaeus. ${ }^{30}$ Although most naturalists were willing to admit that observations of the living animal and its internal parts were a relevant source of information, they tended to rely in their classifications principally on easily visible external characteristics of those animal parts which were preserved in a cabinet. An illuminating example of this practice from the end of the eighteenth century, is the work on shells of Bruguière and Lamarck, mentioned by Daudin. ${ }^{31}$ Bruguière was one of the pupils of Gouan who went to Paris. With Lamarck he shared a special interest in the shells of the so-called Testacea. The two Parisian naturalists emphasized that the study of collections of shells was necessary, not for the arrangement of these collections as such, but as a means to know the relations between the beings which had lived in these shells. Of course, it would be worthwhile to study the animals themselves, but, as Bruguière pointed out; in view of their classification:

rien n'est plus faux et plus illusoire que les caractères que l'on a prétendu tirer des animaux qui habitent les coquilles pour favoriser la connaissance de celles-ci; car ... les coquilles dont les vers ont été observés ne font pas encore la dixième partie de celles dont on ne possède que la partie testacée. ${ }^{32}$

Moreover, even if one wished to study these animals more thoroughly, this would only be possible by observing them in a living state at the places where they could be found. Then, however, the collections would be useless and, as Lamarck observed:

les espèces qui composent ces belles collections resteraient indéterminées, et si quelqu'une l'était par les circonstances convenable, cette détermination ne pourrait pas être confirmée par chaque observateur qui consulterait la collection. Ainsi, la science ne ferait réellement aucun progrès. ${ }^{33}$

From Daudin's detailed history of eighteenth-century zoological classifications, it becomes clear that the use of shells for classification purposes did not pass uncriticized. Objections came, for example, from those who had been studying molluscs alive in the field. Thus, Adanson observed in the preface of his Histoire naturelle du Sénégal that: 
Il y avait donc dans les Coquillages quelque chose de plus à considérer que leurs coquilles; $l$ animal qui les habite devait nous guider dans nos arrangements méthodiques; lui seul devait nous servir de règle, puisqu'il en est la principale partie, celle qui donne à cette espèce de squelette extérieur la forme, la grandeur, la dureté, les couleurs, enfin tous les accidents que nous $y$ adimirons. ${ }^{34}$

Pallas was another naturalist who was not content with the use of shells in classifying the Molluscs. He sought to revise existing classifications of the Molluses on the basis of anatomical investigations, whereby he preferred to study the animals in a fresh state even when specimens of those animals were preserved in a cabinet. Often it appeared to be impossible to dissect the specimens available in a cabinet without defacing the collection and, as Pallas observed, given the state of the macerated material, dissection of fresh animals was more appropriate anyhow. ${ }^{35}$ In Germany, Blumenbach classified the Testacea according to their shells, but not without regretting that natural history had been accommodated to the zeal of amateurs and thus had come to neglect its most important subject: the living animal. ${ }^{36}$

The use of shells in the classification of what was traditionally called the "animals without blood", corresponded of course with the use of external characteristics like teeth, beaks, nails and claws in the classification of the "animals with blood". However, as is illustrated by the very distinction between animals "with and without blood", in zoology characteristics related to the internal anatomy were traditionally deemed significant as well. It was, in fact, only in the eighteenth century that such distinctions were superseded by divisions on the basis of external characteristics, often introduced by naturalists whose principal concern was the arrangement of a cabinet. A typical cabinet naturalist like Klein, for example, divided the animal world according to the presence or absence of feet and thus simply ignored the old distinction referring to blood. ${ }^{37}$ As we have seen, Linnaeus too, based his zoological classifications principally on external characteristics, although in later editions of the Systema Naturae he referred to the internal parts of animals as well.

Linnaeus, then, admitted that anatomical observations were necessary, but, like most naturalists with a primary interest in classification, he never turned to dissection in practice. ${ }^{38}$ Anatomists were, in Linnaeus's classification of botanists, characteristically considered amateurs! So Daubenton, who was responsible for the anatomical descriptions in Buffon's Histoire naturelle, had cause for complaint when he observed that naturalists had wrongly neglected the intemal parts of animals and that: 


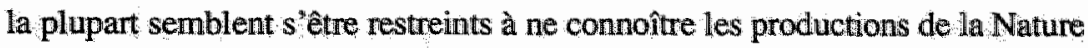
que par l'écorce, semblables à des voyageurs qui ne voudroient voir que les murs des villes ou les façades des palais, au lieu d'entrer dans l'intérieur \& d'examiner en détail tous les chefs-d'oeuvre de l'art qui y sont renfermes. ${ }^{39}$

Instead of describing and comparing animal forms on the basis of only a few external parts, Daubenton wished to make complete descriptions, including all the important organs, internal as well as external. To allow for these descriptions to be easily compared, he stressed that it was necessary to make them all on the same plan, a procedure which he indeed followed in the Histoire naturelle which contained descriptions of external and internal parts of 182 species of quadrupeds.

Félix Vicq-d'Azyr, at one time an assistant of Daubenton, was another physician anatomist who objected to the neglect of the study of anatomy, especially comparative anatomy. Seeking to uncover the total relationships of all animals, including man, Vicq-d'Azyr was not satisfied with descriptions of the general and external form of the skeleton and the main internal organs, on which Daubenton had concentrated. He wished to include articulations, ligaments, muscles, nerves and glands as well as the internal structure of the viscera, all to be studied in each animal. ${ }^{40}$ Anatomy, then, had to become an exact science, and it was, as Corsi observes, clearly Haüy's success in crystallography which inspired Vicq-d'Azyr when he wrote in 1792 that:

Tout organe doit être traitê comme un solide géometrique dont on examinera d'abord à l'extérieur les faces, les bords et les angles, et dont on considerera ensuite l"intérieur avec les mêmes divisions. ${ }^{41}$

In his description of this "French debate" Corsi emphasizes that in France the appeal of the study of anatomy, accompanied. with a zeal to reform its current practice, was by no means an isolated phenomenon. At the end of the eighteenth century, a number of publications appeared with pleas for a refinement of anatomical descriptions as well as the anatomical nomenclature. Moreover, in the view of Pinel, like Vicq-d'Azyr a physician anatomist and member of the Société d'Histoire naturelle, a more thorough anatomical knowledge should also have its consequences on the level of zoological classifications. Reflecting in 1792 upon the work of Linnaeus, Brisson and Buffon, he deemed their results unsatisfactory and declared that: 
nous sommes arrivés à une époque oû on ne peut faire des progrès réels à 1'Histoire naturelle des grands animaux qu'en établissant les caractères des genres et des espêces, non seulement sur quelques apparences extérieures et souvent arbitraires, mais encore sur les rapports immuables de structure mecanique que présentent ... les squellettes des animaux; car c'est là l'avantage des sciences exactes, d'introduire une précision rigoreuse et une sorte d'invariabilité dans la marche de l'esprit humain. ${ }^{42}$

\section{The cabinet, the field and the scalpel}

Which characteristics might serve as a basis for a natural classification of animals? That had become, in any case in France at the end of the eighteenth century, a matter of intense debate among many naturalists, whatever their sympathies or antipathies regarding the work of a Linnaeus or a Buffon. Evidently, it was also a question of central concern to Geoffroy and Cuvier in their discussion of the Manmals. Of course, such debates on the significance of characteristics were not new. What was new, however, was a growing concern with internal characteristics and with the interrelatedness of characteristics. As we have seen, there were particular circumstances which, in the eighteenth century, led to an almost exclusive use of external characteristics in zoological classifications. So what circumstances were leading to a change in this widespread practice?

In the foregoing I already indicated that, in eighteenth-century zoology, there was often a great distance between the naturalists nomenclators, who ruled the practice of classification from their cabinets, and those naturalists who observed animals in a living or fresh state. The minute observations by naturalists like Réaumur and Bonnet on the life history of insects or the reproduction of aphids, however interesting by themselves, were often too incidental to be of value for a naturalist who aimed at a systematic description and comparison of a large number of species. ${ }^{43}$ On the other hand, those descriptions and comparisons, dependent as they were on collections of preserved specimens, often had to remain superficial, especially in those cases where the living animal was almost unknown. For example, during the eighteenth century, there were only a few naturalists who had observed and dissected some of the various marine creatures that could be found at the sea-shore. Linnaeus, then, made it clear that for the classification of these creatures, as well as many others of the "Worms", he could only appeal to scant observations, which, however, did not keep him from attempting such a classification, using a few conspicuous, discriminating characteristics. ${ }^{44}$ In fact, as Daudin points out, those few naturalists who observed and dissected marine animals in a living or fresh state, were often indif- 
ferent to exact classifications, whereas naturalists with an interest in classification, like Linnaeus, Bruguière or Lamarck, were seldom inclined to undertake such dissections themselves. ${ }^{45}$ A naturalist like Pallas, who dissected animals with a view to their classification, obviously was an exception.

The situation was much the same with the study of other animals like the Quadrupeds. To be sure, these animals were occasionally dissected. However, in the eighteenth century, such dissections were undertaken not by naturalists aiming at a classification, but by physicians hoping to perfect the practice of medicine. The anatomy lectures at the Jardin du Roy were devoted to human anatomy and were regularly attended by medical students who wished to supplement the bookish courses offered by the faculty of medicine. Daubenton, for example, had been one of them. ${ }^{46}$ Delivering these lectures had become, according to Gillispie, a sideline for successful doctors who were assisted by a demonstrator qualified in surgery. Later in the century, one of those demonstrators, Antoine-Louis Mertrud, occasionally gave separate, but ill-attended demonstrations in animal anatomy. ${ }^{47}$ In fact, it was Buffon who introduced animal anatomy at the Jardin as a subject for independent study through his decision to offer Daubenton the post of "garde et démonstrateur du Cabinet" with the task, not only to arrange the collections, but also to supply anatomical descriptions for the Histoire naturelle.

It is interesting, then, to read how Buffon defined anatomy as a subject in the context of his natural history. In his famous initial discourse Buffon made it clear that the description of animals would be all the more complete if they were joined to an exposition of internal organs. But he also warned that:

... ce seroit un objet etranger à l'Histoire Naturelle que d'entrer dans un examen anatomique trop circonstancié, ou du moins ce n'est pas son objet principal, \& il faut réserver ces détails pour servir de mémoires sur l'anatomie compareé. ${ }^{48}$

Moreover, as Daudin points out, both Buffon and Daubenton considered man as the indispensible point of departure and principal subject of anatomical comparisons. Therefore, they were only concerned with the anatomy of those animal forms that were sufficiently near to man to render a mutual comparison meaningful. ${ }^{49}$ Eventually, Daubenton supplied anatomical descriptions for the fifteen volumes on the Quadrupeds. Then, his collaboration with Buffon collapsed, perhaps as a result of a significant incident: Buffon, that is, decided to omit the anatomical articles from a new edition of the Histoire naturelle, possibly because he believed them to be somewhat dull. ${ }^{50}$ 
Whatever the vicissitudes of Daubenton's anatomical descriptions, his position at the Jardin du Roy undoubtedly gave him the opportunity to develop the practice of animal anatomy. But it was not the only opportunity created in this field, nor was it the only opportunity for Daubenton. Albury has argued that in eighteenthcentury medicine there was a growing interest in systematic anatomical investigations, reflecting the emergence of a surgical orientation, whereby "surgery, although still regarded as distinct from medicine, had freed itself from its traditional guild association with unlettered barbers and become established as a learned profession" ${ }^{51}$ He further observes that animals became a more important subject for medical research as a result of their increasing economic importance as sources of food and clothing. In France, for example, veterinary schools were opened in the 1760 's. In 1778, a "Société royale de médecine" was established with the responsibility of studying epidemic diseases of beasts as well as man, an event which marked the institutionalization of a state-organized effort to fight cattle plagues on a scientific basis. As a consequence, "animals became medical objects in their own right, rather than as surrogates of humans; and the peculiarities of their organization became the subject of special study". 52

I have already mentioned Vicq-d'Azyr. His career exemplifies the development just indicated, a development which, in fact, he energetically helped to organize. ${ }^{53}$ Being a physician and anatomist, he became chairman of the cattle plague commission, which had been named in 1774 by the Académie des Sciences at the request of the French government. One of his activities in that function was the establishment of two laboratories to study cures and transmission, with a staff consisting of a doctor, a veterinarian and an apothecary. When the commission was prolonged in the form of the Société de médicine, he became its permanent secretary. In addition, Vicq-d'Azyr lectured on anatomy, first for two years at the Jardin du Roy, then at the "Ecole d"Alfort", a veterinary school near Paris, where he was assigned the course in comparative anatomy. Animal or comparative anatomy was also the principal subject on which he published. One of his major publications, which appeared in 1792 as a volume of the Encyclopédie méthodique, was titled Système anatomique. Quadrupèdes. ${ }^{54}$

The sudden termination of Daubenton's collaboration with Buffon marked a shift in his activities, but not the end of his interest in animal anatomy or physiology. Daubenton, too, profited from an increased interest in the study of animal husbandry. ${ }^{55}$ With government support he started a long-term programme of research, directed at the improvement of the quality of French wool. It was research that involved him in the examination of metabolic processes as well as an extensive breeding programme. Daubenton also became a member of the cattle plague commission of Vicq-d'Azyr and, like the latter, he was appointed to a chair at the veterinary school at Alfort, devoted to rural economy. 
So, we see how the careers of both Vicq-d'Azyr and Daubenton reflected new opportunities for studying animals, opportunities which they exploited by approaching that study in a way that virtually no one had done before. Whereas naturalists had been comparing animal forms, and anatomists had been disseeting human bodies, Daubenton and Vicq-d'Azyr both dissected and systematically compared a variety of animals. They were physicians in that they principally studied the Quadrupeds, retaining man as the model for their anatomical research, but they were naturalists too, criticizing their fellow naturalists for being too much concerned with the surface of things.

\section{The animal economy}

With his rejection of the surface of things as the prime focus of concern, Daubenton did not simply suggest a more adequate method of classification. He apparently conceived of a more serious interest when he wrote in 1753 , in the fourth volume of the Histoire naturelle:

J'aurois voulu examiner toutes les epèces d'animaux, s'il étoit possible de les rencontrer, \& mon dessein a été de les observer, tant à l'intérieur qu'à l'extérieur, pour décrire les proportions des parties principales de leur corps, parce que cette description des parties extérieures suffit pour faire distinguer chaque animal, \& celle des parties intérieures pourra donner une idée des principaux organes qui servent aux animaux, \& des modifications de chacun de ces organes dans les différentes espèces. Une telle exposition du corps des animaux peut fournir, par la comparaison que l'on fera des uns aux autres, des résultats importans pour l'économie animale, qui est le principal objet de l'Histoire Naturelle. ${ }^{56}$

Thus, Daubenton proclaimed the so-called animal economy as the principal object of natural history, and presumably not without some self-interest. Actually, in the mid-eighteenth century, it was a concept familiar to a physician or anatomist rather than to a naturalist. Its medical overtones are clearly conveyed in the Encyclopédie, in which it was defined as:

... l'ordre, le mécanisme, l'ensemble des fonctions et des mouvements qui entretiennent la vie des animaux, dont l'exercice parfait, universel, fait avec constance, alacrité et facilité, constitue l'état le plus florissant de santé, dont le moindre dérangement est par lui-même maladie, et dont l'entière cessation est à l'extrềme diamétralement opposé à la vie, c'est-à-dire la mort. ${ }^{57}$ 
Balan has pointed out that the concept of "economy" was well entrenched in medical practice and that, although it was used in various meanings, it somehow expressed the idea of the integrity of the body which had to be maintained against ubiquitous destructive forces. ${ }^{58}$ The term was also found in the concept of the "economy of nature", which, according to Balan, was used independently by naturalists in a distinct manner. Linnaeus, for example, referred with it to the geographical distribution of beings as well as the harmony of their interrelationships. In fact, the content of the concept of "animal economy" is interpreted by Balan as the result of the transference of questions of health, disease and death to the study of animalls, whereby these questions also suggested a relationship of the existence of animals with the prevailing conditions in their environment.

It is clear then that Daubenton, when he introduced the animal economy as the principal object of natural history, was not introducing one or the other internal characteristic of animals as a more adequate basis for their classification. What he wished to emphasize was the integrity of the animal as a whole, that is, the mutual relations between all parts, internal as well as external. What were the implications of such a view for the practice of classification? For Daubenton it was evident that a natural classification of animals would only be possible by taking into account the animal as a whole. The naturalist, that is, had to examine all the principal parts and to analyse the resemblances and differences with the corresponding parts of other animals. Only then, could he establish the essential characteristics that constitute natural groups. ${ }^{59}$ Methodical classifications, in which characteristics were selected a priori and were invoked in some arbitrary order for making divisions, were considered by Daubenton to be pure conventions. To be sure, in his quality of "garde du Cabinet" he did not completely reject such methods. More than once he proved to be satisfied with an artificial system referring to external characteristics only; but he castigated those who dared to pretend that such classifications followed the march of nature. ${ }^{60}$

Evidently, for Daubenton, the study of anatomy in the first place revealed the intricacies of the animal economy. That it was also the key to a natural classification he did not doubt, but often that was more a promise than a practice. Thus, his work demonstrates in an interesting way the distance that separated the point of view of an anatomist from that of a naturalist. It was this very distance which Vicq-d'Azyr in his Systeme anatomique proposed to eliminate, noting that:

il est vraisemblable que la méthode qu'on doit preférer pour classer les animaux à la manière des naturalistes n'est pas celle qu'on doit adopter lorsqu'on se propose de les ranger dans l'ordre qui convient le mieux à l'anatomie ... Dans l'histoire naturelle, on ne considère que les formes extérieures. 
L'anatomie proprement dite borne son examen à la structure interne. $\mathrm{Ni}$ l'une ni l'autre de ces classifications n'est la veritable méthode naturelle. Je les fait marcher ensemble, persuadé que l"étude de l'intérieur et de l'extérieur d'un animal doivent appartenir à la même science. ${ }^{61}$

As an anatomist Vicq-d Azyr emphasized the bond between anatomy and physiology, proposing that one should follow successively the vital functions and then study the organs which subserved them. ${ }^{62}$ He listed nine special functions all related to the three general animal functions - nutrition, movement, and sensation - which then, in the words of Coleman, would serve as a basis for "the presentation of the organ system[s] performing [them], followed in turn by complete descriptions of the individual organs and a review of the appearance or nonappearance of these parts in the different animal species". ${ }^{63}$ However, for Vicq-d'Azyr a purely anatomical investigation of organs was clearly not sufficient. If a true, natural method was the ultimate goal one had to study internal and external parts together. Indeed, like Daubenton, Vicq-d'Azyr observed mutual relations between all parts, internal as well as external. He also inferred relations between the conformation of these parts and the mode of life of the animal, as for example the mutual relations between the structure of the teeth, muscles, toes, claws, tongue, stomach and intestines in carnivorous animals. ${ }^{64}$

Thus, a programme was outlined according to which natural history, anatomy, and physiology would become one science. Vicq-d'Azyr would never realize this ambitious goal. But, as Daudin points out, he certainly was not the only one who aspired to it. For example, Storr, a German professor in medicine, chemistry and botany, in 1780 published a distribution of the Mammals, based on the principle that a zoological classification must take into account the physiologically most important organs. ${ }^{65}$ However, in Storr's view, external characteristics might well be significant in this respect, because they often appeared to be related to a mode of life and therefore also to the existence of less visible, physiologically important parts. For example, the hoof excludes certain movements and can therefore only belong to animals that feed in a particular way and thus have particular teeth and intestines. According to Daudin, it has probably been Storr's work that inspired Cuvier when writing a memoir with Geoffroy on a new classification of the Marmmals. In any case, it is clear that their memoir neatly reflected the way in which, at the end of the eighteenth century, several naturalists or anatomists were seeking to transform the practice of zoological classification. Certainly, this was only a beginning. To succeed, a programme clearly was not enough; conditions for zoological research had to be changed as well and, as we will see, it was precisely that which Parisian naturalists were attempting to achieve. 


\section{A museum of natural history}

For the naturalists at the Jardin du Roy, the outbreak of the Revolution brought threats as well as opportunities. An immediate threat was a proposal to reduce the budget. In an attempt to turn a threat into an opportunity, the naturalists at the Jardin suggested a reform of their institution that, as Appel observes, "would at the same time suit their needs and be in keeping with revolutionary ideals". ${ }^{66}$ So it was proposed to the Assemblee nationale that twelve professorships should be established in the different branches of natural history, with equal rights to everyone, constituting a veritable "Museum national d'histoire naturelle" which thus could become "a sort of metropolis for all the sciences useful to agriculture, commerce, and the arts". ${ }^{67}$

Of course, each professor should have his obligations regarding research and instruction. ${ }^{68}$ So the professors assigned to mineralogy, botany, the culture of plants, zoology, and anatomy should have the task of augmenting, arranging and cataloguing the collections pertaining to their field. With regard to instruction it was especially recommended that the professor of human anatomy should attempt to clarify the structure of man by reference to that of animals, whereas the professor of animal anatomy should demonstrate, through dissections, the internal organization of the various animal classes, notably those which were least known.

By a decree of 10 June 1793, the very year of the eradication of all academies including the Académie des Sciences, the Muséum was established and was placed, entirely in accordance with the original proposal, under the control of twelve professors. ${ }^{69}$ All available chairs were assigned to those who had worked at the Jardin, then in very different hierarchical positions. Thus it was that the chair in animal anatomy was given to Mertrud, the old demonstrator of anatomy, whereas Geoffroy Saint-Hilaire, the young protégé of Haüy and Daubenton and just appointed subkeeper and subdemonstrator of the Cabinet, became professor of mammals and birds. Two years later, the ageing Mertrud urgently needed an assistant who could give the courses in animal anatomy and in this capacity, Georges Cuvier entered the newly created world of Parisian naturalists.

However, in this world there was more to be created than positions. Already before the Muséum was established, both the naturalists at the Jardin and those active in the Sociêté d'Histoire naturelle had made it clear that instruction and research in zoology could not do without a menagerie. ${ }^{70}$ Plants could be examined alive in the Jardin and, preferably, in the field. But for the study of animals there were chiefly the remains exhibited in the Cabinet, locked up behind a window to be admired by the public rather than examined by a student. So, without forgetting to point out the usefulness of a menagerie for other than scientific purposes, it was stated in the regulations for the Muséum: 
Lorsque le Muséum aura les moyens d'entretenir dans une ménagerie les animaux vivants de diverses classes, les professeurs de zoologie seront charges de les decrire, d'étudier leurs moeurs; ils chercheront également à acclimater, muitiplier et distribuer les espèces utiles. ${ }^{71}$

With the establishment of the Museum the menagerie was indeed realized and, in fact, that was only the beginning of a zealous effort through which all sorts of collections in the Muséum were enormously enlarged. ${ }^{72}$ Initially, the opportunities to do so were largely the result of the Revolution and the events that followed it. For example, the menagerie received the animals that were left from the royal collection at Versailles; the library and collections of the Museum were filled with the confiscated property of "emigré nobles"; and some of the professors of the Muséum followed in the wake of Revolutionary and Napoleontic armies, bringing back collections confiscated from the invaded countries. A most valuable collection, for example, was taken from the Stadholder of Holland which contained not only a large number of zoological specimens, but also living animals, among which two elephants. So in 1805 Cuvier could write:

C'est une chose vêritablement admirable que le concours d'objets précieux d'histoire naturelle dont notre établissement s'enrichit chaque jour, et l'on peut dire qu'il n'est nulle part au monde une position plus favorable à celui qui désire étendre le domaine de cette belle science. ${ }^{73}$

But the abundance of confiscated collections was nothing compared to the flow of material and information that was to come from explorations and surveys of areas outside Europe. ${ }^{74}$ In this case, indeed, the disruptions of the Napoleontic wars in the early nineteenth century had been a hindrance, and it was in particular after 1815 that such explorations and surveys were undertaken on a large scale. From that time, collecting was organized at the Museum with the help of a special budget for the training and expeditions of "voyageurs naturalistes" who were sent to diverse parts of the world. Moreover, sizable collections were obtained through government expeditions, related to the expansionist policies of France as one of the major colonial powers. Appel provides figures which illustrate well the unprecedented growth of the collections which resulted from all these efforts. ${ }^{75}$ In 1822 the Museum had become the largest zoological repository in the world containing over 40,000 species of mammals, birds, reptiles, fish, insects, etc. There had been created a collection of 11,486 anatomical preparations, among which were skeletons, teeth, brains, eyes, hearts, viscera, and dissected molluscs and other "invertebrates". The menagerie contained over 500 species of foreign animals and the library was filled with 15,000 volumes. 
Thus, by the early nineteenth century the Museum had become a real stronghold of zoological research. Instead of a Cabinet filled with a variety of objects, stacked up in a few rooms, there were now various specialized collections, housed in different buildings or "galleries", and controlled by different professors. ${ }^{76}$ Geoffroy, for example, was responsible for the menagerie and the zoology collections, whereas the collections of comparative anatomy and palaeontology were created by Cuvier. It is evident that especially Cuvier's collections signified the growing ambitions of those who vindicated the stady of anatomy. But there were others with ambitions too. Revealing in this respect is Cuvier's observation in his autobiography that it was:

... tantôt secondé par quelques professeurs, tantôt contrarié par d'autres, que je parvins à rendre ma collection si importante que bientôt personne n'osa $s^{\prime}$ opposer à son agrandissement. ${ }^{77}$

In her analysis of Cuvier's career, Outram has emphasized that the arrangement and display of different collections within the Museum reflected, and helped to establish, various competing practices and opinions. The arrangement of Cuvier's comparative anatomy collection was a clear visualization of his critical stance against the use of external characteristics in natural history. In the words of Outram, his "galleries differed from the older collections in that they followed an order dictated by physiological systems and their hierarchies ... Cuvier's galleries were full of objects to be looked not at; but into" ${ }^{78}$ Unlike Pallas thirty years before, Cuvier even did not shrink from dissecting animals that were part of the precious collection preserved in alcohol. ${ }^{79}$ But other professors at the Muséum, without denying the importance of anatomy as a basis of zoological classification, were not inclined to follow his approach. ${ }^{80}$ Lamarck, who held the chair of worms and insects, referred if possible to shells when classifying invertebrate animals, and Lacépedde, the professor of fish and reptiles, likewise preferred to use external characteristics in his methodical arrangement of fish. So, at the Museum the debate on the significance of characteristics materialized into different collections, displaying "as many different classificatory systems as there were chairs to which Cabinets were attached". 81

Evidently, the Muséum was a community in which collections and people were closely knit. The majority of the staff actually lived on the grounds, with immediate access to the collections and often accompanied by relatives or protégés with whom they worked on particular projects. Outram even speaks of a series of "households" occupying a place "where many of the different views of what nature was; and who was to control and explain it, uneasily jostled together within the same physical space" ${ }^{82}$ It was in this space that Cuvier and Geoffroy started to work together, but, as we will see, they would end their careers in completely different "households". 


\section{A transformation reconsidered}

My description of natural history in chapter one ended with the conclusion that in our attempts to understand the abstractions of naturalists we should keep in view both the circumstances and opportunities that made these abstracting activities into a large-scale enterprise and the particular theoretical and epistemological ideals in terms of which these activities were justified. No doubt, this is also true for the history of zoological classification as I have described it in this chapter. To understand this history, we first of all have to appreciate the particular circumstances in which animals were being studied in the eighteenth century. As we have seen, those circumstances were very different for a cabinet naturalist aiming at a classification, a field naturalist with an interest in the living animal, or a physician anatomist in search of medical knowledge. Such differences evidently help us to explain why in creating systems of classification, naturalists in the eighteenth century were so very much concerned with the surface of things. Moreover, if we want to understand why naturalists in France at the end of the century began to place more emphasis on internal characteristics as a necessary basis for classification in zoology, we may again point to changing circumstances which led to new opportunities for a more thoroughgoing study of the animal body.

But in this case too, an appeal to such circumstances is clearly not enough if we want to understand what naturalists were doing. No doubt, in the eighteenth century the choice of characteristics to be used in a system of classification was often dictated by the existence of collections which had no more to offer than skins or shells. But this choice also depended on various and shifting ideas on how to proceed in creating a system. Thus, pleas for reform of the practice of zoological classification came from naturalists who were inspired by the idea of a natural method. And, as the history of the Museum d'histoire naturelle shows, such ideas also had their impact on the way collections were made up. Naturalists, then, were not simply the captives of circumstances, but also attempted to change those circumstances in keeping with their own ideals. Indeed, the development of natural history during the years of the revolution is very illuminating in this respect. As we have seen, in those times natural history was glorified for reasons which did not necessarily correspond to the scientific interests of naturalists themselves, but which naturalists nonetheless gratefully seized upon in an attempt to create unprecedented opportunities for teaching and research.

Thus, the professors of the Museum succeeded in creating a world of esoteric scientific activity with specialized collections, courses, textbooks, journals, etc. ${ }^{83}$ Seen from a Latourian perspective, such an inside world could only be 
created by building up, under often difficult and changing circumstances, an outside world of many different allies: individual patrons, political institutions, armies, foreign correspondents, students, a variety of audiences. ${ }^{84}$ However, seen from the archaeological perspective of Foucault, there is in this history of network building something much more important to point out. At the end of the eighteenth century, French naturalists created a world that, according to Foucault, was radically different from the world of classical natural history. That difference we will see only if we shift our attention from the daily preoccupations of naturalists to the underlying rules which constituted a new space in which a science of biology could emerge. Before I turn to Foucault's analysis, however, I will first discuss in detail the work of two naturalists who both played such a prominent, albeit very different, part in transforming the world of natural history. 


\section{References}

1. On the reception of Linmaeus's work in France, see Stafleu, 1971; and Daudin, $1926 \mathrm{~b}$, chapter 1 , pp. 3-21. For an account of Linnaean natural history in eighteenth-century Germany, see Larson, 1979.

2 Thus, in his discussion of taxonomy in eighteenth-century France, Stafleu contends that the attitude towards systematics and towards nature, of French naturalists like Adanson, de Jussieu and Lamarck, "led to the establishment of biology as a modern discipline". Mbid, , p. 291. See also my discussion in the Introduction.

3. Corsi, 1982. See also Corsi, 1988, chapter 1.

4. Geoffroy and Cuvier, 1795. All the quotations in this section are taken from this memoir.

5. Chapter II, p. 47.

6. Daudin, 1926a, p. 120 .

7. Stafleu, 1963.

8. Quoted by Daudin from Adanson's Familles des Plantes (1763). Daudin, 1926a, p. 122 .

9. Ibid., pp. 121-124. See also Stafleu, 1971, pp. 310-320.

10. Ibid., pp. 204-209.

11. Quoted by Stafleu from a letter written by de Jussieu to Sir James Edward Smith (1789). Stafleu, 1971 , p. 323.

12. Daudin, 1926a, pp. 209-213.

13. Ibid., pp. 188-204.

14. Ibid., p. 125.

15. Daudin, 1926b, chapter 1, pp. 3-6.

16. Daudin, 1926a, p. 120 and pp. 144-145; Stafleu, 1971, p. 281.

17. Stafleu, 1971, chapter 9. See also Appel, 1987, pp. 15-16.

18. Appel, $1987, \mathrm{p} .15$.

19. Gillispie, 1980, pp. 192-193.

20. Gillispie, 1957. See for a critical discussion of this point: Corsi, 1988, pp. 7-10.

21. Gillispie, 1957, p. 267.

22. Daudin, $1926 \mathrm{~b}$, chapter 1, pp. 7-11.

23. Corsi, 1982, p. 384 .

24. Daudin, 1926b, chapter 1, pp. 19-21.

25. Corsi, 1982, pp. 388-389. See also Albury and Oldroyd, 1977; and Stevens, 1984 .

26. Quoted by Corsi from Daubenton's "Observations sur les noms imposés aux pierres nouvellement découvertes, lues à l'ouverture du Cours de Minéralogie, le premier floreal an VI". Tbid., p. 393.

27. Ibid.

28. Daudin, 1926b, chapter 1, pp. 12-14. 
29. Ibid., chapter 2, pp. 139-140.

30. Chapter I, p. 36, Chapter II, pp. 57-58.

31. Daudin 1926b, chapter 1, pp. 16-18.

32. Quoted by Daudin from Bruguière's "Sur deux nouvelles espèces de Térebratules fossiles" (1792). Ibid., chapter 3, pp. 221-222.

33. Quoted by Daudin from Lamarck's "Sur les Coquilles, et sur quelques-uns des genres qu'on a etablis dans l'ordre des vers testacés" (1792). Ibid,, chapter 1, p. 17. Burkhardt observes that Lamarck's interest in conchology was also highly motivated by the importance of shells, and their fossil counter-parts, for the debate on the reality and the extent of species extinction. See Burkhardt, 1977, pp. 128-130.

34. Quoted by Daudin from Adanson (1757). Daudin, 1926a, pp. 151-152.

35. Ibid., pp. 149, 152 and 158.

36. Daudin, 1926b, chapter 3, p. 218.

37. Ibid., chapter 2, p. 110.

38. Daudin, 1926a, pp. 74-75.

39. Quoted from Daubenton's "De la Description des Animaux", in Buffon, 1753, IV, p. 119. See also Daudin. Ibid., pp. 132-135.

40. Coleman, 1964, pp. 46-51.

41. Quoted by Corsi from the preface to Vicq-d'Azyr's Système anatomique. Corsi, 1982, p. 390. See also Corsi, 1988, p. 28.

42. Quoted by Daudin from Pinel's "Recherches sur une nouvelle methode de classification des quadrumanes". Daudin, 1926b, chapter 1, p. 18. See also chapter 2, p. 135 .

43. Daudin, 1926a, pp. 49-50.

44. Daudin, 1926b, chapter 3, pp. 210-215.

45. Ibid., chapter 3, pp. 221; chapter 1, p. 48.

46. Gillispie, 1980, p. 164.

47. Ibid,, p. 177.

48. Buffon, 1749, I, p. 30.

49. Daudin, 1926a, p. 155.

50. Farber, 1975, pp. 64-65.

51. Albury and Oldroyd, 1977, pp. 210-211. See also Gillispie, 1980, pp. 204-206.

52. Ibid., p. 211. See also Gillispie, 1980, pp. 24-33.

53. Gillispie, 1980, pp. 29-33 and 196-203.

54. Coleman, 1964, pp. 46-51.

55. Gillispie, 1980, pp. 165-168.

56. Quoted from Daubenton's "De la Description des Animaux", in Buffon, 1753, IV, p. 135. See also Farber, 1975, p. 67.

57. Quoted by Balan from Diderot and d'Alembert, 1765, XI, p. 360.

58. Balan, 1979, chapter 2. 
59. Daudin, 1926a, pp. 134-136, 220 and 223; Farber, 1975, pp. 70-72.

60. Daudin, 1926a, pp. 154-156; Daudin, 1926b, chapter 1, pp. 39-41.

61. Quoted by Daudin. Daudin, 1926a, pp. 224-225.

62. Coleman, 1964, pp. 46-51.

63. Ibid., p. 49.

64. Corsi, 1982, p. 390. See also Daudin, 1926a, p. 226, note 1.

65. Daudin, 1926a, pp. 221-223. See also Daudin, 1926b, chapter 2, pp. 136-138.

66. Appel, 1987, p. 17. See also Corsi, 1988, pp. 10-13; and Daudin, 1926b, chapter 1, pp. 22-25.

67. Appel, 1987, p. 18.

68. Daudin, 1926b, chapter 1, pp. 34-37.

69. Appel, 1987, pp. 18-19. See also Corsi, 1988, p. 13; and Daudin, 1926b, chapter 1 , pp. 37-38.

70. Daudin, $1926 \mathrm{~b}$, chapter 1, pp. 26-30. See also I(sidore) Geoffroy Saint-Hilaire, 1847, pp. 44-45

71. Quoted by Daudin from E.T. Hamy, Les derniers jours du Jardin du roy et la fondation du Muséum d' Histoire naturelle (1893). Ibid., chapter 1, p 29.

72. Outram, 1984, p. 164; Appel, 1987, pp. 34-36; Daudin, 1926b, chapter 1, pp. 30-32.

73. Quoted from Cuvier, 1805, III, p. xil See also Daudin, 1926b, chapter 1, p. 33.

74. Farber, 1982a, pp. 33-41; Daudin, 1926b, chapter 1, pp. 32-34.

75. Appel, 1987, p. 36 .

76. Outram, 1984, pp. 175-178.

77. Quoted from Cuvier's autobiography (partly) published in Flourens, 1856, I, p. 183 . See also Outram. Ibid., p. 176.

78. Outram, 1984, p. 176.

79. Daudin, $1926 \mathrm{~b}$, chapter 1, p. 66 . See also Cuvier, $1800, \mathrm{I}$, p. ix.

80. Ibid., chapter 1, pp. 70-84.

81. Outram, 1984, p. 178.

82. Ibid., p. 171.

83. Appel, 1987, pp. 34-39.

84 Latour, 1987, chapter 4 . See Outram, 1984, chapter 8 , for a very interesting account of the many ways in which the naturalists of the Muséum were tied to the outside world. 
CHAPTER V

\section{CUVIER AND GEOFFROY}

\section{Two diverging careers}

In the foregoing chapter I have described how in France at the end of the eighteenth century the practice of zoological classification was debated by naturalists who emphasized the importance of anatomical and physiological knowledge as a prerequisite for a natural classification of animals. We have seen that the features of this debate were clearly reflected in the memoir of Geoffroy and Cuvier on a new classification of the Mammals. However, this memoir obviously also reflected the individual experiences, convictions and ambitions of its authors. In this chapter I will focus on these individual experiences, convictions and ambitions, because it was in pre-eminently the work of Geoffroy and Cuvier which, in the first half of the nineteenth century, came to shape and transform processes of abstraction in natural history. But, as we will see, Geoffroy and Cuvier shaped and justified their abstracting activities in completely different ways.

In fact, their memoir of 1795 marked the beginning of two very different careers. Cuvier, although a newcomer in the Parisian world of naturalists, was the dominating figure from the start. At the time they wrote their memoir on the Mammals, Cuvier was far more experienced in the field of natural history than Geoffroy, and he undoubtly was chiefly responsible for the style and content of the memoir. In the years that followed he quickly rose to the status of recognized scientist and gradually acquired a variety of prominent positions, not only as a scientist, but also as educator and administrator. In the shadow of Cuvier's career Geoffroy soon went his own way. Motivated by different experiences, convictions and ambitions than Cuvier, he ultimately became his bitter opponent.

\section{Georges Cuvier}

What was the nature of Cuvier's experience at the time he went to Paris in the hope of securing a position at the newly established Museum d'histoire naturelle? He had been thoroughly educated in Germany where he had been prepared for an administrative career, a study which introduced him to a great var- 
iety of subjects, including branches of science like chemistry, mineralogy, zoology, botany and geometry. ${ }^{2}$ In his student days Cuvier also found some friends with whom he could share his interest in natural history and with whom he founded a natural history society which embodied, in the words of Outram, "a co-operative programme of the description and redefinition of species ${ }^{*}{ }^{3}$ In these years it was also through personall contact with an older fellow student, Kielmeyer, that $\mathrm{Cu}$ vier learned how to dissect.

After his graduation in 1788 Cuvier went to Normandy to become tutor to the son of a noble family in Caen. Finding himself in a rather isolated position, Cuvier tried to maintain his German connections through a regular correspondence and continued to pursue the "Linnaean style" programme of description of species, exploiting as much as he could the local resources in natural history, such as the botanical garden of the town, private collections of fish and oriental birds, and the university library. ${ }^{4}$ However, his new environment also offered ample opportunities to study animals captured in the field, like birds and marine forms of life. That was especially the case from 1791 onwards, when Cuvier, accompanying the family of his pupil, moved to a residence a few miles from the Norman coast. Although Cuvier obviously found it difficult to leave the town where cabinet and garden had been within reach, he now was close to the sea and could range the fields, where he could feel, as he wrote to his German friend Pfaff, "nothing but a naturalist". 5

What all these activities meant to Cuvier we may gauge from his letters to Pfaff, written during the first four years of his stay in Normandy. A few months after his arrival, Cuvier wrote that he was working at a new project of a "general natural history" according to which:

on devrait rechercher soigneusement les rapports de tous les êtres existants avec le reste de la nature, et montrer surtout leur part dans l'économie de ce grand Tout. ${ }^{6}$

Cuvier added to these words that an understanding of all beings in relation to the whole of nature amounted to a study of the degree of complexity and the necessary effects of their properties, as well as the utility of these properties in the Creation. To exemplify the approach he had in mind, he referred to the ancient works of Aristotle and Pliny, but also to the "dry and meagre" words which Linnaeus had devoted to the "economy of nature". Of Buffon, whose aim had also been a general natural history, Cuvier remarked that he had lost himself too much in his imagination, piling up one hypothesis on another. ${ }^{7}$

In Cuvier's view a science had to be built on experience, stripped of any hypothesis. In this respect he often referred, in his letters to Pfaff, to develop- 
ments in chemistry and physics, sciences which he considered as the principal pillars of natural history. He enthousiastically described the new chemistry of Lavoisier which contained, as he said, neither hypotheses nor vague demonstrations. ${ }^{8}$ Yet, in formulating his project of a general natural history, Cuvier obviously had in view a particular kind of experience. Experience as it was embodied, for example, in his observations on the treecreeper, which we find described in the same letter in which he defined his project. In this description, Cuvier observes that the tongue of the treecreeper is hard and inflexible, in contrast to that of the woodpecker. He then explains that the cause of this difference became clear immediately upon dissection of the animal. It appeared that its stomach contained insects which couldn't have been eaten with a tongue like that of the woodpecker, which is geared to picking soft larvae. This also explains why the conformation of the stomach of the tree-creeper differs from that of the woodpecker. $^{9}$

During his seven years stay in Normandy Cuvier kept diaries in which he described hundreds of distinct varieties of birds, plants, insects and molluscs, for which, according to his own recollection, the tenth edition of Linnaeus"s Systema naturae served him as a companion and guide. ${ }^{10}$ But Cuvier evidently had other ambitions than just the perfection of a system of classification. As we have seen, he wished to understand living beings in their relation to the whole of nature, which implied for him that one should study the relations between the functional activities of animals and the anatomy of their parts. Thus, describing an animal was more than defining it in terms of a few conspicuous external characteristics. One also had to dissect it, to see how form and function were interrelated in the conformation and composition of its parts. " So in his letters to Pfaff, Cuvier repeatedly referred to dissections of birds, fishes and other marine creatures, taking for their description the work of Daubenton as his example. ${ }^{12}$

But what did Cuvier think of classification, the preoccupation of so many naturalists in the eighteenth century? In the letter to Pfaff in which he formulated his general project, he gave as his view that systems of classification were a means and not the end in natural history. ${ }^{13}$ Almost two years later he wrote in the same vein that:

les classes, les ordres, les genres, sont de simples abstractions de l'homme, et rien de pareil n'existe dans la nature .... Nota bene que je suis cependant convaincu de l'utillité de ces abstractions. ${ }^{14}$

However, several months later, in another letter to Pfaff, Cuvier seemed to go a step further, warning his friend that in creating a system one must not simply rely on the most conspicuous characteristics, but only on those parts which are shaped: 
semblablement chez les genres semblables, afin d'eviter des séparations ou des réunions quí ne seraient pas naturelles. ${ }^{15}$

In other words, Cuvier now seemed to think it possible that a system represents natural affinities, a possibility that undoubtedly had been suggested to him through his reading of the Genera Plantarum of 1789 , in which de Jussieu used his particular way of calculating the value of characteristics as the basis of a natural method in botanical classification. ${ }^{.16}$ It appears that, as soon as he became acquainted with this work, Cuvier began to apply its principles, not only in his own botanical studies, but also in a classification of insects. Thus, in 1791 he discussed the relative value of antennae, lips and jaws in defining those groups of insects which he deemed evidently natural, concluding that the lower jaw was the most important because its characteristics could be invoked in a classification without rupturing incontestable affinities. ${ }^{17}$

In this discussion Cuvier also referred to what he called metaphysical considerations. He explained that jaws were more important than antennae because nutrition is a precondition in animal life, which means that the conformation of the organs of mastication will be related to the entire mode of life and whole organization of the animal. Conclusion: characteristics taken from the organs of mastication will necessarily indicate natural divisions in the animal world. ${ }^{18}$ So, from 1791 on, Cuvier no longer tended to regard systems of classification as a purely conventional and subsidiary expedient to the description of species. On the contrary, he now apparently began to conceive of a way to relate his project of a general natural history to genuine attempts at classification, attempts that in 1795 led to its first visible results in his joint memoir with Geoffroy.

\section{Two worlds in one}

Cuvier"s early experience in natural history is interesting because the distance which in zoology often divided naturalists working in a cabinet from those who observed animals in a living or fresh state, was conspicuously lacking in his work. To be sure, during his stay in Normandy, a cabinet and library were resources which he could scarcely do without in maintaining his Linnaean-style programme. But Cuvier was also in the position to study animals in the field and, being familiar with dissection from his student days in Germany, he described animals externally as well as internally. Thus, the cabinet, the field and the scalpel all contributed towards the realization of his project. As a pupil of Cuvier recalled much later, it was considered so self-evident at the time that the study of anatomy was an occupation of physicians that in Paris it was generally assumed that Cuvier had a medical degree. ${ }^{19}$ 
Although Cuvier's background in natural history thus was very different from that of Daubenton or Vicq-d'Azyr, who indeed were physicians, he shared with them a particular conception of animal form. Like them, he conceived the animal body as a functional whole, characterized by mutual relationships between different parts depending on the mode of life of the animal. Like them, he sought to establish a comparative anatomy from this perspective. But in contrast to Daubenton and Vicq-d'Azyr, who by virtue of their medical background were mainly interested in the higher animal forms, Cuvier in Normandy also extensively studied insects and molluscs or what he called, after Linnaeus, the "animals with white blood". ${ }^{20}$

However, this was not the only difference. We have seen that both Daubenton and Vicq-d'Azyr considered the study of anatomy as a precondition of a natural classification of animals. Yet, neither of them really attempted or managed to construct a genuine natural system. In their work the interest of the physician anatomist in the animal economy, and the interest of the cabinet naturalist in nomenclature and elassification remained largely disconnected. Although in $\mathrm{Cu}-$ vier's world of experience there was never a large distance between these two spheres of interest, he too intitially perceived systems of classification as a means that was only subsidiary to his project of a general natural history. However, once he had knowledge of de Jussieu's work, Cuvier actually began to conceive of a way to inform systems of classification with his conception of the animal economy. The very reason why his memoir with Geoffroy is such an interesting document is that it represents his first public achievement in this direction. Moreover, Cuvier did not leave it at that. Within a month he read another memoir for the Société d'Histoire naturelle in which he proposed a new classification of the animals with white blood, usually called "Worms", based on his intimate knowledige of the anatomy of these creatures. ${ }^{21}$

\section{On Mammals and Worms}

How did Cuvier succeed in relating systems of classification to a conception of the animal economy? First of all he adopted from the work of de Jussieu the principle of subordination of characteristics. As we have seen, subordination was based by de Jussieu on a procedure in which he determined the value of characteristics as indicators of natural groups by observing their relative constancy in those groups of plants that were evidently natural. ${ }^{22}$ Cuvier then applied this procedure in his early discussion of insect classification and also in his memoir with Geoffroy on the Mammals. In the latter case, it was argued that the superior value of characteristics taken from the organs of touch was con- 
firmed by their constancy in some incontestable natural orders. However, as is evident from my discussion of this memoir in the foregoing chapter, in Cuvier's line of thought, considerations like these were only of secondary importance. No doubt, the principal, and most innovative, argument of the memoir was that subordination had to be based on considerations relating to the functional dependencies of the animal economy.

In a penetrating analysis of Cuvier's work, Daudin has observed that the principle of subordination seems difficult to reconcile with a conception in which mutual relations between organs are emphasized. ${ }^{23}$ How to determine the relative importance of characteristics taken from two different organs when these organs are interdependent in the animal economy? We know the answer from the memoir on the Mammals: in the animal economy some organs have a preponderant influence, that is, those which are most directly related to the existence and mode of life of the animal. Hence, it is the conformation of these physiologically most important organs which determines the constitution of most others. Cuvier formulated this basic idea most explicitly in his memoir on the Worms. In pursuit of, as he said:

une espèce de divisions des vers qui ... me permet d'exprimer d'un seul mot,

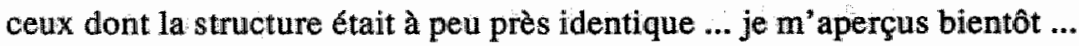
qu'ici, comme dans toute le reste de son ouvrage, la Nature a travaille sur un certain plan, a formé des groupes sensiblement rapprochés, et qu'elle a subordonné les organes les uns aux autres; de sorte que l'identité des principaux entraine une grande ressemblance dans la plupart des autres. ${ }^{24}$

Cuvier then presented a first division of the animals with white blood as a clear example of the fecundity of this principle of subordination and the laws to which it might lead. To begin with, he distinguished three large groups: those with a heart and a complete vascular system which have gills; those with only a simple dorsal vessel without a heart which have trachea; and those which have neither a heart, nor vessels, nor respiration. Cuvier now stated as a law that all the animals with white blood which have a heart also have gills, whereas the animals without a heart merely have trachea as a means to bring the body into contact with the ambient air or water, and he explained that:

Chacun sent maintenant que la force musculaire du coeur était nécessaire pour porter le sang dans les innombrables ramifications des branchies; que le coeur cessant, le sang ne pouvant plus aller chercher l'air, il a fallu que l'air vînt le chercher. 25 
As another example of a "beautiful and new" law, Cuvier referred to the observation that the liver is only found in those animals which have a heart and gills, which he explained on the basis of the "advanced opinion of chemists" that the liver is the organ where the blood is dephlogisticated. So, this organ has no function when there is no true circulation and the ambient air is transported by trachea. In other words, the liver is subordinated to the heart and gills, whereas the existence of the gills depends on that of the heart, whereby indeed in the latter case Cuvier seemed to think of a mutual dependence rather than subordination. ${ }^{26}$

Thus, in the memoirs on Mammals and Worms, Cuvier made the animal economy a relevant consideration in the classification of animals and in so doing he assured that the ensuing classifications would be natural. That is, the functional relations between organs, constituting the laws of the animal economy, suggested to him a way to represent the various characteristics of the whole animal by a description of only its primary parts. Because those animals that resembled each other for these primary parts, would necessarily resemble each other for the majority of the other parts, and so, would constitute a natural group. For example, the conformity between the primary organs of the Molluscs - the heart, vascular system and gills - did not merely involve, according to $\mathrm{Cu}$ vier, a comparable conformity with respect to the liver, but also with respect to a countless number of other characteristics and thus it was undoubtly justified to consider the Molluses a natural group. ${ }^{27}$

Cuvier, as Coleman points out, very probably saw the justification of subordination in terms of functional dependencies, as a truly philosophical approach to natural history. ${ }^{28}$ However, as is apparent from Cuvier's work, this subordination was rarely if ever invoked as an a priori principle from which a system of classification simply could be derived. The basic idea was that one had to find characteristics indicating the features of the animal organization as a whole, in order to represent the majority of characteristics "in just one word". In theory one had to take these characteristics from the physiologically most important organs, which could be known by reasoning, as Cuvier put it. But in practice, other, more empirical and mundane considerations evidently had to play a part. ${ }^{29}$ We have seen, for example, that Geoffroy and Cuvier argued in their memoir on the Mammals that organs of touch were more important than any other of the sense-organs, because the organs of touch lent themselves to the most numerous, salient and rigorous divisions. They also preferred the organs of touch to the organs of nutrition as a source of indicating characteristics, because the first were external, whereas the latter were partly internal. In his memoir on the Worms, Cuvier, it is true, rejected classifications based on shells, intimating that no philosophical naturalist could object to the use of anatomical characteristics in zoology. ${ }^{30}$ But in a second memoir on this subject he con- 
sidered the mantle of the Molluscs as an external characteristic which pre-eminently indicated this class of animals, since the existence of a mantle appeared to be related to the existence of the primary internal organs of the Molluscs. ${ }^{31}$ Thus, insights relating to the animal economy were accommodated to the practice of zoological classification and vice versa. In other words, in relating the point of view of a naturalist to that of an anatomist, Cuvier transformed those points of view as well.

\section{Becoming a legislator of science}

Cuvier's presentation of the memoirs on Mammals and Worms before the Société d'Histoire naturelle was only one step in a zealous effort to make himself known and to acquire a secure position within the world of Parisian naturalists. As we have seen in the foregoing chapter, this world had been profoundly transformed in the years before 1795. The Académie des Sciences had been abolished, several of its members had been imprisoned or sentenced to death and scientific life in the capital had been dispersed into private scientific societies like the Société d'Histoire naturelle and the Société Philomatique. It was especially in these societies that Cuvier was able to contact well-known scientists and to establish, as Outram puts it, his first claims to recognition in science. ${ }^{32}$ Indeed, already before he came to Paris, Cuvier had made contacts with some Parisian naturalists and it was through these contacts that, early in 1795, he had applied to a post at the Muséum d'Histoire naturelle and had been appointed assistant to Mertrud, the professor of animal anatomy. Together with Geoffroy, and benefitting from the collections of the Musêum, Cuvier presented in that year not only his general memoir on the Mammals, but also several other memoirs on the classification of particular mammalian species. ${ }^{33}$ His manifold activities evidently made a profound impression. When at the end of 1795 the old Académie des Sciences was resurrected in the form of the First Class of the Institut de France, Cuvier, at the age of 26 , was elected a member of the new section of anatomy and zoology. ${ }^{34}$ Much later, Cuvier would recall in his autobiography that he found himself well enough known to expect that he would be named. As an explanation of his success, he wrote:

Ce qui me donna le plus de faveur parmi les savants, c'est que j'étais presque le seul alors qui envisageât l'histoire naturelle sous un point de vue philosophique et raisonné qui fít entrer l'anatomie dans la zoologie. ${ }^{35}$ 
No doubt, Cuvier's thorough education, his long experience in the country of Normandy and his contacts with naturalists in Germany, made for his rapid rise to prominence. But, as Appel points out, this rise was also due to "his ability to identify patrons and to publicize his talents". ${ }^{36}$ Thanks to this ability Cuvier succeeded in availing himself of every opportunity that came his way to strengthen his position in the world of science. Actually he owed these opportunities to a large degree to his position at the Muséum. How important this position was to him becomes clear from his refusal in 1798 to participate as a scientific member in Napoleon's military expedition to Egypt. Later, in his autobiography, he would comment that:

Mon calcul fut bientôt fait. J'étais au centre des sciences, et au milìu de la plus belle collection, et j'y êtrais sûr d"y faire de meilleurs traveaux, plus suivis, plus systématiques, et des découvertes plus importantes, que dans le voyage le plus fructueux. ${ }^{37}$

Cuvier, then, preferred to be a cabinet naturalist rather than a naturalist voyager. Whereas, in his opinion, the latter more or less rapidly traversed some diverse lands, being unable to conserve of his observations more than "isolated and fugitive traces", the first had his cabinet in which he could traverse the universe in all directions, "passing in review" all its productions with ample time to study and compare them. ${ }^{38}$

But the collections at the Muséum were not the whole story of Cuvier's mobilisation of opportunities. ${ }^{39}$ It was a regular practice that teaching opportunities in prestigious public instititutions like the Collège de France were taken by those who were already teaching at the Muséum, a practice which secured the professors of the Muséum additional audience as well as income. Thus $\mathrm{Ca}$ vier was appointed at the Collège de France even before he became titular professor of comparative anatomy at the Muséum in 1802. The Muséum provided also a number of subordinate positions which offered Cuvier and the other professors the opportunity to appoint young naturalists and protégés to help them in teaching and research. Moreover, as Cuvier's career advanced in several directions, his influence as a patron soon went beyond the walls of the Muséum. When in 1803 he became one of the two permanent secretaries of the First Class of the Institut de France, he was given, in the words of Appel, "unparalleled opportunity to pass judgment on his predecessors and contemporaries ... through his reports on others' work, his annual analyses of the work of the Institut, and his éloges of deceased members". "From 1808 on, as Inspector-General and member of the Council of the newly established Imperial University, Cuvier also acquired a significant influence on appointments within the university sys- 
tem. In his quality of administrator he was further charged with the supervision of public education in the French Empire, whereby several tours outside France gave him ample opportunity to visit valuable collections and to maintain his contacts with naturalists in foreign countries. ${ }^{41}$

Evidently, the vicissitudes of Cuvier's career were bound up with profound changes in French society during and after the Revolution. Institutional changes like the establishment of the Muséum d'Histoire naturelle and several reforms of the educational system created, as Appel points out, a small but growing number of opportunities for a full-time career in natural history. ${ }^{42}$ French naturalists, among whom several of Cuvier's pupils, benefited from this circumstance and constituted nuclei around which, at the beginning of the nineteenth century, a science of zoology began to crystallize. But it was Cuvier who shaped this science more than anyone else. Characteristically, his contemporaries honoured him with the title "legislator of science". ${ }^{43}$ Using and extending the large collections at the Muséum, and with the help of pupils, protégés and correspondents, Cuvier not only laid the foundations of a science of comparative anatomy, but also led the way in the emerging science of paleontology and at the same time created what he perceived as a genuine natural system of zoological classification. Of course, Cuvier"s strength as a legislator of science was not only a question of material and institutional resources, it depended as much on the way in which he forged all these elements together into one comprehensive project aimed at the laws which constituted animal form and, thus, the plans of nature.

\section{The laws of animal organization}

Three multivolumed works, which were all published in the first two decades of the nineteenth century, clearly showed the comprehensiveness of Cuvier's project: the Leçons d' anatomie compareé, the Recherches sur les ossemens fossiles des quadrupèdes, and Le règne animal distribué d'après son organisation. In Cuvier's approach the different subjects of these works - comparative anatomy, the study of fossil bones, and classification - were intimately linked, but at the same time it is clear that of these subjects anatomy ranked first. In one of his lectures on comparative anatomy, Cuvier proposed a classification of the natural history sciences, just like Linnaeus had done in his Bibliotheca Botanica more than fifty years before. However, unlike Linnaeus, who had placed anatomists at the bottom of the list (together with gardeners, physicians, astrologers and chemists), Cuvier mentioned anatomy first. ${ }^{44}$ In the Leçons, the authorized publication of Cuvier's lectures on comparative anatomy, it is explained why. ${ }^{45}$

There, Cuvier introduced the idea of life as a notion which forces itself upon 
anyone who observes how the integrity of a living body is maintained against destructive physical and chemical forces. As such, however, life is a phenomenon which is very difficult to grasp. Life is a "torrent", in which "molecules" continuously enter the body, are combined with other molecules in a constant manner and, after some time, are separated and excreted again. Of course, we can study the material constituents of the body so formed, but for Cuvier it was clear that, in doing so, much remains invisible and escapes from our instruments. Moreover, whereas in chemistry and physics we may greatly simplify our problems by studying phenonomena in isolation and by subjecting each substance to various experiments, this cannot be done in physiology, because:

Les machines qui font l'objet de nos recherches ne peuvent être démontées sans être détruites; nous ne pouvons connoître ce quì résulteroit de l'absence d'un ou de plusieurs de leurs rouages, et par conséquent nous ne pouvons savoir quelle est la part que chacun de ces rouages prend à l'effet total. ${ }^{46}$

So, how to disclose the operations which are apparently concealed in this "impenetrable laboratory"? Cuvier had a clear answer:

C'est à l'anatomiste à y porter les premières lueurs: c'est à lui de fäire connoître au physiologiste la partie matérielle des phénomènes et les instruments des opérations. ${ }^{47}$

For Cuvier, anatomy stood first because he saw the organization of the body as the most palpable manifestation of life. He saw, that is, organization as a result and as a precondition of the action of vital forces. So, it is through the study of the facts of animal organization that the anatomist may hope to ascend to general causes. Therefore, it is not enough that the anatomist simply describes the different parts of the animal body. He must carefully compare the many different forms of organization, to understand what is essential and what is accessory and how the different parts are affected by their various combinations with other parts. Fortunately, nature has performed the experiments which the physiologist cannot do himself. For:

Elle nous présente dans les differentes classes d'animaux presque toutes les combinaisons possibles d'organes; elle nous les montre réunis, deux à deux, trois à trois, et dans toutes les proportions; il n'en est, pour ainsi dire, aucun dont elle n'ait privé quelque classe ou quelque genre; et il suffit de bien examiner les effets produits par ces réunions, et ceux qui résultent de ces privations, pour en déduire des conclusions très vraisemblables sur la nature et l'usage de chaque organe et de chaque forme d'organe. ${ }^{48}$ 
Thus, by making anatomy comparative one exploited the experiments of nature and instead of a laboratory one needed a collection. In the Leçons, Cuvier made it clear that he considered himself very fortunate with a most beautiful collection presenting him with all the parts of the animal body taken from a great variety of species. ${ }^{49}$ Thanks to that collection, he said, comparative anatomy had almost become a game, in which one could observe "at a glance" all the variations and successive degradations of each organ. Yet it was a glance which involved, as Cuvier acknowledged, the sustained efforts of more than one man; and which filled five stout volumes with detailed descriptions of all the important organs in all groups of animals.

Although Cuvier had high hopes of the physical sciences as the principal pillars of natural history, he emphatically distinguished comparative anatomy as a science of observation from physics and chemistry as sciences of calculation and experiment. Whereas in physics it was often possible to deduce the facts from known principles and in chemistry one could perform exact measurements, in comparative anatomy work had to be reduced to the description, or "history", of facts. Cuvier, of course, had more in mind than mere description. We have seen that he always sought to interpret anatomical facts in functional terms and that he perceived these facts as a clue to the understanding of the animal economy. Hence, Cuvier opened the Leģons with reflections on the animal economy, beginning with a description of the functions exercised by the animal body in which he especially emphasized how these functions act upon each other. He also emphasized the fact that the organs which exercise a particular function can be very different in different groups of animals, given different modes of life and the mutual dependencies between organs. ${ }^{5 !}$ In fact, it was these very differences that Cuvier identified as the principal subject of comparative anatomy. What he achieved in the Leçons was no more and no less than a systematic examination of the different ways in which the same function is exercised in different groups of animals, to begin with the organs of locomotion, then followed by the organs of sensation, etc.

What were the results of this programme? The first result which Cuvier put forward was a hypothetical one. If indeed each function is excercised in different ways and it is supposed that the different modes of one kind of organ combine with the different modes of all the others, then there would be a great number of different combinations which would answer to an equal number of different classes of animals. But as Cuvier immediately pointed out:

ces combinaisons, qui paroissent possibles, lorsqu' on les considère d"une manière abstraite, n'existe pas toutes dans la nature, parce que, dans l"état de vie, les organes ne sont pas simplement rapprochés, mais qu'ils agissent les uns sur les autres, et concourent tous ensemble à un but commun. ${ }^{52}$ 
In other words, many conceivable combinations of organs are in fact excluded as a result of mutual dependencies in the animal economy. An animal, that is, can only exist on the condition of a functional harmony between all its parts, which means that:

C'est dans cette dépendance mutuelle des fonctions, et ce secours qu'elles se prêtent réciproquement, que sont fondées les lois qui déterminent les rapports de leurs organes, et qui sont d'une nécessité égale à celle des lois métaphysiques ou mathématiques ... ${ }^{53}$

So it is evident that the restrictions pertaining to a science of observation did not exclude, in Cuvier's opinion, the establishment of genuine laws in comparative anatomy. He even believed that in principle it was possible to "deduce" the laws of animal organization from an analysis of mutual functional dependencies or, what he called, the conditions of existence. ${ }^{54}$ In the Leçons for example, he assured that the constant relationship between the mode of respiration and the way the nutritive fluid is moved through the body, necessarily followed from an understanding of the raison d'etre of these vital functions. It was a point indeed which he had also made in his early memoir on the Worms. He further reasoned that there must be a constant relationship between the mode of respiration and the activity of the body in general, because it was known from recent experiments that the principal function of respiration was the reanimation of the muscular force. Thus, he thought it possible to explain through an "almost mathematical deduction" why animals with a very effective, pulmonary respiration always have well developed powers of movement, sensation, circulation and digestion. ${ }^{55}$ Cuvier admitted that the laws of animal organization could not always be deduced that way. Why, for example, was there a constant relationship between the existence of lungs or gills and a more or less centralized nervous system? In cases like this, however, he did not doubt that it was justified to assume that the observation of constant relationships between organs indicated veritable laws, and thus, mutual influences still unknown.

Cuvier, then, was convinced that the laws of animal organization had their source in the functional dependencies of the animal economy, but this conviction did not prevent him from invoking such laws in cases where these sources were unknown. An example of this practice were Cuvier's reconstructions of fossil quadrupeds, published in a series of memoirs which ultimately were collected in his Recherches sur les ossements fossiles. ${ }^{56}$ Cuvier was the first to achieve a systematic and detailed comparison of fragmentary remains from fossil quadrupeds with skeletons from similar modern animals. Using his extensive anatomical knowledge, he succeeded in reconstructing a great number of fossil 
species and showed them to be different from contemporary species. In a general account of his method Cuvier emphasized that for these reconstructions a few fossil bones would do, because:

Tout être organisé forme un ensernble, un système unique et clos, dont les partics se correspondent mutuellement et concourent à la même action défunitive par un réaction réciproque. Aucune de ces parties ne peut changer sans que les autres changent aussi; et par conséquent chacune d'elles, prise séparément, indique et donne toutes les autres. ${ }^{57}$

Thus, it was Cuvier's claim that, given the laws of animal organization, that is, given the way in which different parts of a skeleton coexist, it was possible to conjecture the complete structure of an animal from the observation of a few bones. However, it is significant that the constant relations between the parts of a skeleton were denoted by Cuvier as "correlations". Since the causes of these relations often were unknown, the naturalist must, in Cuvier's opinion:

suppléer au défaut de la théorie par le moyen de l'observation; elle nous sert à établir des lois empiriques qui deviennent presque aussi certaines que les lois rationelles, quand elles reposent sur des observations assez répétées ... ${ }^{58}$

Cuvier's pronouncement was anything but a casual remark and reveals, as both Coleman and Daudin point out, the very style of his research. That is, in his studies of animal organization, Cuvier generally resorted to the observation of correllations rather than to their rational, a priori explanation. No doubt, such explanations were all-important to him. Yet, it was first of all the facts of comparative anatomy which suggested to him the laws that implied, in his own words, all the properties of the animal body in the manner of an "equation of a curve" ${ }^{59}$

\section{The plans of nature}

From Cuvier's early papers it is evident that his anatomical studies not only led to spectacular reconstructions of fossil animals, but also were at the root of attempts at an all-embracing reform of zoological classification. Problems of classification continued to occupy Cuvier's mind during his whole career. In the Leçons he pronounced that the natural method ought to form the goal of all efforts of naturalists, but it was a goal which would only be attained when classification and anatomy went hand in hand. ${ }^{60}$ After he had published his Leçons and his Recherches, Cuvier returned to the natural method as the ideal of natural history in 
another monumental work, the Règne animal. It was the first systematic work since Linnaeus's Systema naturae which contained a classification of the entire animal kingdom. ${ }^{61}$ Moreover, it was generally agreed that the order of Cuvier's detailed exposition of all known animals indeed approached a true, natural system of classification. In consequence, his work quickly became, in the words of Coleman, "the standard zoological manual for most of Europe ${ }^{\mathrm{t}}{ }^{62}{ }^{2}$

In Cuvier's project, anatomy and classification actually were conceived as two sides of the same coin. In his view, the study of anatomy was not simply the indispensible beginning of a natural method. He also saw the natural method as a precondition of a science of comparative anatomy. As Cuvier explained in the Leçons, comparative anatomy would become a very laborious affair if one had to enumerate each time all those animals in which a particular organ has the same structure. It would be much easier indeed if one could simply indicate those animals through the name of a class or genus. So a neat, comparative exposition of organs presupposed a natural system of classification in which classes or genera are composed of those animals which resemble each other for the majority of their organs. Of course, such a classification presupposed a thorough knowledge of the organization of all animals. Hence, in the Regne animal Cuvier made it clear that his project had compelled him:

... faire marcher de front l'anatomie et la zoologie, les dissections et le classement; chercher dans mes premières remarques sur l'organisation, des distributions meilleures; m'en servir pour arriver à des remarques nouvelles; employer encore ces remarques à perfectionner les distributions; faire sortir enfin de cette fécondation mutuelle des deux sciences l'une à l'autre, un système zoologique propre à servir d'introducteur et de guide dans le champ de l'anatomie; et un corps de doctrine anatomique propre à servir de developpement et d'explication au système zoologique. ${ }^{63}$

Cuvier's early memoir on the Worms was a most illuminating example of his procedure. Having dissected a great number of specimens, Cuvier attempted to arrange the white-blooded animals according to the features of their organization as a whole. This showed him, as he said, that nature (as always!) had worked upon a certain plan. A plan which was embodied in a number of distinct classes and which revealed some fundamental laws of organization. These laws then indicated a few primary organs which, given their constant relationships with other parts, could be used in a system to represent the ensemble of properties that were common to each class. Thus we have what Cuvier defined as the principle of subordination, according to which the most general groups of the animal kingdom had to be represented by characteristics taken from the most in- 
fluential or most constant organs. In this way the creation of a system became a means to reduce, as Cuvier put it, a science to the greatest possible economy of words, that is, to elevate its propositions to the greatest possible generality. ${ }^{64}$

However, in the light of this aspiration to reduce the science of natural history to a minimum of words, the animals with white blood remained a subject of both interest and trouble. In 1812, five years before the Règne animal appeared, Cuivier published an article in which he reflected on the grand distinction between "vertebrate" and "invertebrate" animals which had been introduced by Lamarck as the real foundation of the well-known partition of the animal kingdom into animals with red and white blood. Cuvier agreed that Lamarck's distinction was perfectly justified, but he also pointed out that between both groups of animals there was a striking lack of symmetry which he had been attempting to abolish for a long time already. Cuvier then explained that in his courses on comparative anatomy it indeed appeared to be easy to arrive at a great number of general features common to the four classes of the vertebrates. But, in the case of the invertebrates the situation was different, because:

chaque instant après avoir tracé d'une manière générale les lois qui président à l'organisation des animaux vertébrés, je retombois dans des particularités quand je voulois parler des animaux sans vertèbres, que l'on oppose sans cesse aux autres et que l'on considère en quelque façon comme une seconde moitié du Règne animal. ${ }^{65}$

Happily, Cuvier could tell his readers that he had traced the cause of the inconvenience. Being too respectful of previous usages, as he said, he unjustly had assigned the title of class to the distinct groups of invertebrate animals, implying for example that the Molluscs formed a group of the same order as the Mammals. But now it was clear to him that three large divisions of invertebrates - Molluscs, Articulata, and Radiata - constituted groups that were no less important than the entire series of vertebrate animals. So, Cuvier announced that he had found:

qu'il existe quatre formes principales, quatre plans généraux, d'après lesquels tous les animaux semblent avoir été modelés, et dont les divisions ultérieures, de quelques noms que les naturalistes les aient décorées, ne sont que des modifications assez légères fondées sur le développement ou sur l'addition de quelques parties, mais qui ne changent rien à l'essence du plan. ${ }^{66}$

Cuvier's attempts to discuss the features of animal organization at the highest level of generality thus led him to accept a new conception of the plans of na- 
ture. The result satisfied him especially because the four basic divisions or, what he called, "embranchements" seemed to be justified by experience as well as reason. It appeared that in each embranchement the nervous system had a particular structure. And, Cuvier declared, the nervous system was the essence of the animal to which all the other organs conformed. No wonder that all animals within the same embranchement resembled each other in the general disposition of their parts.

Of course, Cuvier's argument was a rationalization of empirical evidence, but it was not completely ad hoc. ${ }^{67}$ In the Leçons he had already pronounced that movement and sensation, the so-called animal functions, were the most important because of their preponderant influence on vital functions like digestion and circulation. Moreover, in a series of unpublished lectures which followed the Leçons, Cuvier more specifically emphasized the functional importance of the nervous system. ${ }^{68}$ Indeed, in his classifications Cuvier had used the possession of a nervous system as the outstanding characteristic which distinguished animals from plants. ${ }^{69}$ But, it was only with the introduction of his embranchements that he began to apply this principle as a major distinguishing characteristic between animals themselves. At last, the repartition of the animal kingdom was reduced to a few words and it was, Cuvier concluded, amazing to see:

à quel point ce changement si léger en apparence dans les méthodes reçues, donne de facilité et de netteté aux propositions de l'anatomie comparée. ${ }^{70}$

\section{The bounds of continuity}

In the Regne animal Cuvier arranged his detailed descriptions of all known animals according to a subdivision of each embranchement into classes, orders, genera and species, thus making the four embranchements the foundation of the long-desired natural system. However, we have seen that in the thinking of most naturalists the ideal of a natural method was not only bound up with a notion of natural groups, but also with a persistent notion of continuity between those groups. Buffon was of course a most conspicuous example. Indeed, he rejected any system of classification for the very reason that nature passes from one form to the other by imperceptible nuances. But we know that Linnaeus, the respected creator of systems, also thought of a true natural system as an ensemble of groups with relationships on all sides. In this he was followed by the early proponents of a natural method, Adanson and de Jussieu, who both conceived of their natural families of plants as continuously shading into each other. So what about Cuvier, who, in his letters to Pfaff, had so often praised de Jussieu? 
There is no simple answer to this question because Cuvier's thoughts on the notion of continuity gradually changed. But, one thing is clear. His attitude towards the way this notion was used in zoological classifications was critical almost from the start. ${ }^{71}$

Cuvier's first published statement on the notion of a continuous chain of being we find in the Leçons. To begin with, he observed that the accessory parts of beings show much more variation than their primary parts and he also immediately pointed out the reason. If there are no conditions which restrain nature in her fecundity, everything which is possible seems to be realized. Thus, whereas nature is bound to a restricted number of possible combinations between the modifications of the important organs, there is boundless variation in all accessory parts. We now see; Cuvier explained, why naturalists always observe such abundant variation at the surface of beings where nature has placed the least important parts! And, among these endless combinations of external parts:

il s'en trouve nécessairement beaucoup qui ont des parties communes, et il $y$ a toujours un certain nombre qui ne diffèrent que très-peu, en sorte q'en plaçant les unes auprès des autres celles qui se ressembles plus, on peut en établir une espèce de suite qui paroîtra s'éloìgner comme par degrếs d'un type primitif. C'est sur ces considérations que reposent les idées que certains naturalistes se sont formées d'une échelle des êtres qui les ressembleroit tous en une série unique ... ${ }^{72}$

Cuvier clearly did not accept the way in which naturalists often attempted to place the multiplicity of beings into a continuous chain and his objections were, as Daudin points out, typical for those who combined knowledge of anatomy with an interest in natural history. Naturalists who held the idea of continuity in high esteem often sought to confirm this notion by relating different classes of animals through intermediary forms which shared some salient, external characteristics with either class. Thus, bats, sea-lions, and flying fish served as intermediaries between quadrupeds, birds, and fish, linking together these classes into a chain or network of relationships. ${ }^{73}$ But anatomists like Daubenton and Vicg-d'Azyr rejected such links as crude and completely untenable in the light of open-minded anatomical investigations. In their view, it was out of the question that an ostrich or bat could fill the gap between quadrupeds and birds. ${ }^{74}$ Cuvier evidently agreed: the idea of a continous chain of being could be maintained only in the mind of those who held their eyes fixed upon the great variety of secondary and superficial parts.

However, we have seen that the notion of a chain of being also had its roots in the practice of anatomical research. Man generally was considered the most 
perfectly organized animal form, which served as a standard for comparison in anatomical investigations, and as such justified a hierarchical arrangement of animal forms according to a decreasing perfection of their organization. This hierarchical conception of aifferent modes of organization was manifest in the work of a physician anatomist like Vicq-d'Azyr, and it was not less manifest, as Daudin points out, in the work of Cuvier. ${ }^{75}$ Cuvier, however, did not endorse this view without some serious reservations. In the Leģons he observed that each organ, examined in isolation, indeed shows a uniform degradation when it is followed in a particular series of species. But each organ does not exhibit such degradations in the same order. That is, different organs approach their most perfect form in completely different species, which means that it is nearly impossible to arrange species according to a general scale of perfection. Moreover, to observe such gradual degradations of organs one must keep within certain bounds, because:

ces nuances douces et insensibles s'observent bien tant que l'on reste sous les mêmes combinaisons des organes principaux, tant que ces grands ressorts centraux restent les mêmes ... mais du moment où on passe à ceux qui ont d'autres combinaisons principales, il n'y a plus de ressemblance en rien, et on ne peut méconnoitre l'intervalle ou le saut le plus marque. ${ }^{76}$

For Cuvier then there was no unity in the animal world in terms of an all-embracing continuity of more or less hierarchically related forms. There was, no doubt, a fundamental unity on the level of the animal functions, but these functions were exercised in very different ways, bound up with very different modes of life. In the Leçons Cuvier especially referred to the vertebrate and invertebrate animals as beings that were formed upon plans so completely different that it was impossible to relate them to each other by one or the other intermediairy form. In 1812 , he returned to this theme with the introduction of his embranchements, which evidently had confirmed him in the conviction that the animal kingdom was formed on radically distinct plans. Thus, he emphasized that there was not the least nuance between the different embranchements, although the Vertebrates and Molluscs to a certain extent approached each other, since the Cephalopoda one of the classes of the Molluscs - were so complicated that it was impossible:

de trouver aucun autre animal susceptible d'être placé raisonnablement entre eux et les poissons; et dans l'intérieur de la classe il existe une série de dégradations d'un plan commun tout aussi suivie que parmi les animaux vertébrés, en sorte que l'on peut descendre de la seiche jusqu'a l'buitre à peu près comme de l'homme jusqu' a la carpe; mais ce n'est point par un seul ligne que l'on descend ainsi, dans un embranchement pas plus que dans l'autre. ${ }^{77}$ 
To be sure, Cuvier did not deny that one could observe various series of degradations in the animal kingdom, but more and more emphatically he rejected any suggestion, in whatever form, of a serial continuity between all animal beings. In the Regne animal he even remarked that such suggestions had harmed the progress of natural history to a degree that could scarcely be imagined. ${ }^{78} \mathrm{Sev}$ eral years later, in an article on "Nature" contained in the Dictionnaire des sciences naturelles, he castigated the "philosophers" who believed in a chain of being and who pretended that each gap between the known forms would be filled by beings still to be found. ${ }^{79}$ Cuvier answered them that even now that so many species had been collected the gaps still existed. Thus, the distinctions established by "true naturalists" obviously retained all their force. Of course, it could not have been different, because, as Cuvier explained, the laws of co-existence of organs necessarily imply that any significant change in one organ involves a change of all others. These very laws thus exclude all those pretended intermediary forms, supposedly combining parts that in fact can only belong to different beings. Moreover, what applies to an individual being, likewise applies to nature as a whole. That is, all beings of the world are mutually dependent like the organs of the human body: everything what must be is there, and nothing more. So, it is only in the speculative mind that nature is provided with useless beings to fill the gaps in a scale which reflects no more than a philosopher's sense of beauty.

\section{Etienne Geoffroy Saint-Hilaire}

In 1792, at the age of twenty, Geoffroy Saint-Hilaire was a student in Paris whose only ambition was to study mineralogy. ${ }^{80}$ One year later he was the youngest of the twelve professors at the newly established Muséum d'histoire naturelle and found himself responsible for research and instruction in zoology. Geoffroy owed his position not so much to any special competence in this field, but rather to his efforts in the preceding year to rescue his teachers from the revolutionary massacres. One of those teachers was his friend and mentor Haüy, the distinguished mineralogist. As the story goes, it was by way of the intercession of Haily that Geoffroy, half a year after these dramatic events, was selected by Daubenton to fill a vacant post at the Jardin du Roy as subkeeper and subdemonstrator of the Cabinet. When, a few months later, the Jardin was transformed into the Muséum and all who held a position at the former Jardin were raised to the status of professor, Geoffroy suddenly and unexpectedly became professor of mammals and birds. 
Initially, the scientific life of the young and inexperienced professor was clearly dominated by his collaboration with Cuvier, a collaboration which Geoffroy eagerly welcomed and which started shortly after Cuvier's arrival in Paris, early in $1795 .^{81}$ In that year, Geoffroy began to publish his first memoirs, dealing with the classification of various mammalian species. Of the nine memoirs that appeared in 1795 , four were published by Geoffroy and Cuvier together, among which their joint memoir on the classification of the Mammals. Except for this last one, all the memoirs that were published by Geoffroy during his first years at the Muséum dealt with the classification of particular species of mammals and birds, often referring to preserved specimens that had been recently acquired by the Museum from confiscated collections. ${ }^{82}$ As such, this work reflected Geoffroy's responsibility as professor of mammals and birds to augment and classify the zoological collections. Yet these memoirs also revealed a propensity of their author to reflect on more general questions concerning the natural relations in the animal kingdom. As far as such questions had been touched upon by Geoffroy and Cuvier together in their general discussion of the Mammals, it was no doubt Cuvier who had impressed his mark most deeply on this discussion, although there is no reason to believe that Geoffroy did not agree. In his own memoirs, however, Geoffroy revealed himself as someone who also cherished his own particular beliefs.

His first memoir, for example, which dealt with the classification of a peculiar quadruped from Madagascar, was originally provided with a long but never published preface in which Geoffroy critically discussed the doctrine of the chain of being. ${ }^{83}$ As becomes clear from the memoir itself, Geoffroy certainly did not reject the widespread notion of continuity in nature. But, like Daubenton and other Parisian naturalists, he seemed to resist any doctrinal statement of linear continuity because such a linear conception would never allow an adequate representation of the multiple affinities between animals. ${ }^{84}$ We have seen that, as more and more animals were being described in the second half of the eighteenth century, naturalists increasingly began to emphasize the versatility of relations between the multiplicity of forms. ${ }^{85}$ Continuity, then, remained a pervasive phenomenon in the eyes of eighteenth-century naturalists, but it was a continuity embodied in all kind of transitions between different forms rather than in a singular chain.

Geoffroy's early memoirs on classification were, as Daudin points out, most significant in this respect. ${ }^{86}$ In his attempts to classify several little-known exotic species, Geoffroy often tended to consider such species as intermediary forms, that is, as forms which, given the peculiar form of their teeth, toes, limbs, etc., appeared to fill a gap between already established genera. Thus, in a memoir of 1796 on the natural affinities of the makis, Geoffroy distinguished five genera which, however, he did not see as really distinct, because: 
Le galago est ... une espèce mixte, intermédiaire entre les loris et le tarsier, qu"ill semble que la nature ait formée pour qu' il $n^{3} y$ ait pas de saut brusque dans son ouvrage et pour faüre arriver, par une gradation insensible, à la forme si extraordinaire du tarsier, alors unique dans la création. ${ }^{87}$ ?

But the idea of continuity also appeared in this memoir in another, more comprehensive form..$^{88}$ By way of introduction, Geoffroy opened his taxonomic descriptions of the makis with the general statement that it was a constant truth for anybody who had observed a great number of nature's productions that:

il semble que la nature s'est renfermée dans de certaines limites, et n'a formé tous les êtres vivants que sur un plan unique, essentiellement le même dans son principe, mais q'elle a varié de mille manières dans toutes ses parties acessoires. ${ }^{89}$

He then added that it was especially when considering a particular class of animals that this common plan became evident:

nous trouverons que les formes diverses sous lesquelles elle s'est plu à faire exister chaque espèce, dérivent toutes les unes des autres; il lui suffit de changer quelques-unes des proportions des organes, pour les rendre propres a de nouvelles fonctions, ou pour en étendre ou restreindre les usages .... Ainsi les formes, dans chaque classe d'animaux, quelque variées qu'elles soient, résultent toutes, au fond, d'organes communs à tous: la nature se refuse à en employer de nouveaux. Ainsi toutes les différences les plus essen-

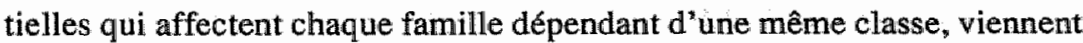
seulement d"un autre arrangement, d'une complication, d'une modification enfin de ces mêmes organes. 90

So, in Geoffroy's view, in each class the various forms of life were related to each other through gradual transitions, showing the various ways in which nature adapted a common plan to particular functional needs. In an interesting discussion of Geoffroy's work, Daudin has argued that Geoffroy's statements on a unity of plan essentially concurred with the views that Geoffroy and Cuvier had put forward together in their memoir on the Mammals. ${ }^{91}$ In that memoir, they had based their classification on the assumption that in a "well-related" system like the animal economy there must be fixed relations between most organs. Thus, as Cuvier put it shortly after in his memoir on the Worms, in all its works nature had followed a certain plan and had subordinated the organs to one another in such a way that the identity of the principal ones implied a great resem- 
blance between most others. But in Cuvier's view, the secondary, less important organs evidently were more variable than the primary ones. That is, these secondary parts, like the feet of the Mammals, might be as different as the wing of a bat and the flipper of a seal. ${ }^{92}$

Geoffroy's general observation that all beings within each class, whatever the variations of their accessory parts, appeared to be formed upon a common plan was thus consonant with Cuvier's cherished notion that the features of animal organization were necessarily and rigorously subjected to laws proper to the animal economy. Yet, in stating these ideas, Geoffroy's principal source of inspiration was probably not Cuvier but Buffon. ${ }^{93}$ Buffon's Histoire naturelle was, as Appel points out, full of scattered references to a single plan that could be followed from man to quadrupeds, cetaceans, birds, reptiles, fishes, etc. Like Buffon, Geoffroy seemed to take this plan as a very general rule which, in his view, might well extend to all living beings. Moreover, unlike Cuvier, who always sought to explain the features of animal organization in terms of underlying functional dependencies, Geoffroy, from his early attempts at classification, seemed primarily to be interested in the visible peculiarities of animal form.

\section{Moving away from Paris}

When, in the beginning of 1798 , Geoffroy and Cuvier were invited to accompany Napoleon on a military expedition as members of a party of scientists, they responded very differently. Cuvier, as we have seen, refused. He saw no point in leaving his position "at the centre of science". Geoffroy, on the other hand, eagerly accepted and so arrived in the summer of 1798 in Egypt where he would stay until the end of 1801 under increasingly difficult circumstances. ${ }^{94}$ During the first year of his stay he participated in a number of expeditions which brought him to different parts of the country and which gave him the opportunity to collect new specimens, especially unusual species of fish. But, as Appel makes clear, Geoffroy's real interests lay beyond mere collecting.

At first he concentrated on comparative anatomy, writing memoirs on subjects like the wing of the ostrich, the frontal prolongations of ruminants and the anatomy of fishes. As to the first subject, Geoffroy showed that in the ostrich one could observe the vestiges of the wishbone common to birds, although the ostrich, being flightless, has no need of such a bone. Nature, so Geoffroy concluded, always leaves the vestiges of an organ even when it is entirely superfluous. As to the antlers and horns of different ruminants Geoffroy attempted to show that they were all of the same nature. Thus, in these anatomical memoirs, 
Geoffroy started to reduce, as Appel points out, various peculiar anatomical structures to common forms.

But Geoffroy did not restrict himself to the study of anatomy. Suffering from poor health, weary of expeditions, and isolated from his colleagues in Paris, he increasingly indulged in reflections of a more theoretical nature. Thus he produced, during the third year of his Egyptian adventure, a series of memoirs in which he discussed various physiological problems, announcing for example "a plan of experiments to arrive at the proof of the coexistence of the sexes in the germs of all animals". This plan was very revealing with respect to Geoffroy's basic conception of animal form. What Geoffroy assumed was that in each embryo both sexes were always present and that, under the influence of the environment, the organs of one sex were developed, while the others were aborted. Moreover, this idea was part of a much more general claim that the "germs" of all those different organs observed in different families of animals existed together in all species and that "the cause of the infinite diversity of particular forms and of the existence of so many half-effaced or totally obliterated organs" was due to a "greater proportional development" of some organs at the expense of others. ${ }^{95}$

We have seen that Geoffroy had, from the very beginning of his career, been suggesting a plan common to all animals in which all organs, in whatever form, are always present. Hence his interest in rudimentary organs in his studies of anatomy. Now, he also conceived of an explanation of this phenomenon in materialist terms, hypothesizing germs which develop at the cost of others under the influence of various environmental conditions. Although Geoffroy attempted to acquire the means that would allow an experimental investigation of his ideas, there is, according to Appel, no evidence that he succeeded. Yet, this was not the end of his theoretical adventure. Evacuated to Alexandria, under siege by the British, and in expectation of his long-awaited return to France, Geoffroy began to labour at what he described as a very extended work on physics, chemistry, and physiology, containing a vast theory in which all physical and vital phenomena were explained on the basis of a few general principles. What he arrived at in these final weeks was, in his view, no less than "a series of deductions which appear to the mind with the character of a perfect lucidity". 96

It is clear that Geoffroy, in following Napoleon to Egypt, had been moving away from Paris not only in a literal, but also in an intellectual sense. That is, with his theoretical speculations he had moved far beyond the questions that were deemed proper to a professional naturalist responsible for description and classification in zoology. Whatever hopes he might have had about his intellectual endeavours, when the moment of retum had come Geoffroy was very well 
aware that his colleagues in Paris might think unfavourably about his ideas. Indeed, the memoirs in which he presented his speculative theorizing were never published. Thus, back in Paris, Geoffroy found himself in a position that was considerably different from that of Cuvier. Whereas the latter had published the first two volumes of the Leçons d'anatomie comparée and was soon to be elected permanent secretary of the First Class of the Institut de France, Geoffroy, in the words of Appel, "could boast of no more than his original chair at the Museum, nor had he published a single major work".97

\section{In search for analogies}

In Paris Geoffroy returned to descriptive taxomical work without, however, losing his interest in questions that were related to his basic conception of animal form. ${ }^{98}$ This interest was apparent, for example, in a number of memoirs published in the first year after his return in which he described the anatomy of fishes gathered in Egypt. Most revealing was a memoir in which he discussed the electric organs occurring in some species of fish. ${ }^{99}$ Noting that electric fishes could be found in very different genera which include many species that are similar but do not have electric properties, Geoffroy persistently searched, as he said, for "something analoguous" to the electric apparatus in related, non-electric species. In his view, for the electric apparatus of the torpedo ray one should find an analoguous organization in the other, non-electric rays, because:

Il ne faut pas avoir comparé entre eux beaucoup d'animaux pour être averti qu'il n'y a jamaĩs parmi eux d'organes nouveaux, sur-tout dans des espèces qui se ressemblent autant que des raies. ${ }^{100}$

Thus, motivated by his general belief that nature always followed a common plan, Geoffroy sought to establish in his memoir "analogies" between organs, whereby he succeeded in showing, for example, that the innervated tubes which seemed to be responsible for the extraordinary electric properties of the torpedo ray were also present in other rays, albeit in a modified form. In other words, for Geoffroy the systematic search for analogies became a means to inform the practice of his anatomical research with the notion of unity of plan, a notion which till then had been no more than a general and speculative idea. According to his own recollection, however, he really began to see how to trace the "philosophical resemblances of organs" when, a few years later, he studied the bones of his Egyptian fishes. ${ }^{101}$ 
In describing the skeleton of fishes Geoffroy had to deal with a problem with which, as Appel points out, every naturalist was faced who compared the parts of different species of animals. ${ }^{102}$ When should one use the same name for structures found in different animals and when should one invent a new name? Usually names were retained when parts had a shape and function similar to those found in man, whereas new names were introduced for parts that appeared to be different. When, for example, Cuvier described and named the wishbone in birds and the gill-cover in fishes he apparently assumed, in the words of Appel, "that these bones occurred only in birds and fishes because they were specialized pieces required for specialized functions, namely flying and respiration under water respectively". 103 According to Appel, it was indeed the publication of Cuvier's Leçons which prompted Geoffroy to his own programme of research of which the first results appeared in 1807 in a series of memoirs on osseous pieces found in fishes and in the skull of the crocodile and birds. ${ }^{104}$

In the very first pages of the first of three memoirs on the fishes, Geoffroy made it clear that he was more than ever convinced that even those organs in fishes that seemed to resist any comparison had their analogues in the other vertebrate animals. ${ }^{105}$ Taking the pectoral fin of the fishes as his subject, he pointed out that several naturalists had compared it to the forelimbs of the quadrupeds, but with varying and uncertain results. Geoffroy then observed that the determination of these pieces indeed was difficult because of the singular position of the forelimbs in fishes compared to the other vertebrates. In his view, however, these difficulties immediately disappeared as soon as one studied the pieces of the arm in relation to the other parts to which they were connected. That is, naturalists had been easily misled by differences in the form and position of organs because they considered each organ separately instead of following the connections between them. ${ }^{106}$

Thus, when Geoffroy identified a clavicle in fishes he justified this claim by describing the way in which this bone connected the sternum to the bones of the pectoral fin. He also identified two omoplates, arguing that in fishes these bones were connected to the clavicles in the same way as in the other vertebrate animals. He even identified a furcula or wishbone, connected to the bones of the shoulder just like in birds. Obviously, this furcula was often difficult to recognize, because in fishes this bone had lost the significant role in flight it had in birds. Yet, whatever its form or function, in fishes a furcula was retained, no doubt, as Geoffroy observed, because of:

l'affinité des poissons avec les oỉseaux, et ... la tendance de la nature à faire reparoître sans cesse les mêmes organes dans les animaux formés sur le même type. ${ }^{107}$ 
However, even with the help of the connections between bones, the establishment of analogies was not always an easy task, as is clearly demonstrated by Geoffroy's determination of the sternum, which was the subject of the third of his three memoirs on the fishes. ${ }^{108}$ Again, it was the anomalous position of the piscine sternum which made it very difficult to recognize. To find out which osseous pieces in fishes were analogous to the sternum and its annexes in the higher vertebrate animals, Geoffroy first resorted to some anomalous species of fish which he considered as intermediary forms that would let him pass, as he said, from the animals with lungs to the fishes by "a less sudden jump". Even by this procedure, the identification of the sternum in the true fishes met with difficulties. Difficulties which Geoffroy attempted to solve by comparing the fishes, not to the other vertebrates in general, but to the birds which embodied, in his view, the type on which the fishes were formed. But ultimately it was only by turning to the avian fetus that Geoffroy could trace the five separate bones which he had found in the sternum in fishes and so could state their identity in fishes and in other vertebrates on the basis of their "position, connections, form and uses". In his conclusion, Geoffroy explained that, given the different ways in which the sternal bones were used in birds and fishes, it was logical that in birds these bones sutured together in a process of ossification, whereas in fishes the ossification process stopped in a much earlier stage.

When Geoffroy in his early years at the Muséum speculated about a common plan on which all animals seemed to be formed, he expressed a thought which already had a long history. Many a naturalist before him had noted the striking correspondences among such diverse organs as the fin of a fish, the wing of a bird and the arm of a man. ${ }^{109}$ But, as Appel points out, almost no one had yet done what Geoffroy more and more consciously set out to do, that is, tenaciously seek out analogies. Geoffroy was, in the words of Appel, "one of the first to analyze osseous structures ... into individual bones, even parts of bones, and to seek bone-by-bone correspondences among mammals, birds, reptiles and fishes". ${ }^{10}$ In doing so, he not only posed a new kind of questions about animal organization, but he also introduced some new means to answer them. In tracing analogies, a naturalist would never lose the thread in the labyrinth of forms, as long as he followed the connections between bones. And, should these connections have disappeared from view in adult forms, then one always could reveal them in the fetus by counting centers of ossification. Thus, when Geoffroy boldly compared forms as different as the skull of fishes and that of man, he had no doubts about the key to his succes. Nature, he said:

tend à faire reparoître les mêmes organes en mêmes nombre et dans les mêmes relations, et elle en varie seulement la forme à l'infini. D'après ce 
principe, je n"aurai jamais à me décider, dans la détermination des os de la tête des poilssons, d'après la considération de leur forme, mais d'après celle de leurs connexions. 11 .

\section{A philosophicall research programme}

In 1818 , Geoffroy presented his anatomical studies in a much more elaborate form in what was his first major work, called Philosophie anatomique. The title of the book was, at least in the eyes of the author, entirely in accord with the spirit of the age. The present epoch, Geoffroy proclaimed in the preface to his work, was a period of philosophical studies. Indeed, in a report on Geoffroy's memoirs of 1807 , no less a person than Cuvier himself had emphasized the importance of Geoffroy's results for "philosophical natural history". ${ }^{12}$ Moreover, inspired by Geoffroy's work, several French naturalists had begun their own search for analogies, extending Geoffroy"s approach beyond the bones of vertebrates to many other parts and to other, invertebrate animals as well. So well-received was Geoffroy's work that, according to Appel, between 1807 and 1818 the search for analogies "threatened to displace the more traditional functional anatomy .... to become the most exciting and challenging branch of comparative anatomy". ${ }^{113}$

If indeed Geoffroy's anatomy was accepted as an exciting, philosophical adventure, in what sense then was it conceived as philosophical? An answer to that question is provided by Geoffroy himself in the preliminary discourse of the Philosophie anatomique. There he observed that naturalists had always been guided in their generalizations by analogies between forms. But often such analogies had been inspired by a vague sentiment rather than by evidence. Should one prefer a principle, even a philosophical principle, to a reality given by observation? Thus, naturalists had generally abandoned the search for analogies, abstaining from any abstract proposition and sacrificing the study of relations to a sort of predilection for details. As a consequence, the foot of a ruminant:

devint pour eux une griffe dans leur histoire de lion; une main dans celle du singe, une aile dans la description des chauve-souris; une nagoire à l'égard de la baleine; etc. Plus de nom commun; l'analogie de ces parties avait cessé $\mathrm{d}^{2}$ être aperçue. ${ }^{114}$

Fortunately, the multiplicity of these isolated observations had again moved naturalists to seek relations between them. So it happened that naturalists gradually returned to the "doctrine of analogues" and began to see how they could follow the forefoot of an animal: 
aussi bien dans ses divers usages que dans ses nombreuses metamorphoses, et le voir successivement applique au wol, à la natation, au saut, a la course, etc.; être ici un outil à fouiller, là des crochets pour grimper, ailleurs des armes offensives ou défensives; ou même devenir, comme dans notre espèce, le principal organe du toucher, et, par suite, un des moyens les plus efficaces de nos facultés intellectuelles. ${ }^{115}$

In Geoffroy's account, all this inevitably led up to the present epoch, in which natural history thrived on philosophical studies, that is, on the search for relations between the multiplicity of anatomical observations. But, how to determine such relations if one was unwilling to content oneself with vague and confused impressions? In Geoffroy's eyes, it was clear that general propositions on animal form were only possible with reference to the connections between parts, because, as he said, an organ was sooner altered, atrophied, or annihilated than transposed. Thus, only on the basis of connections, could we see an organ from a general point of view, and from there we might descend to an examination of its various metamorphoses and uses. Then, indeed, we would succeed:

à considerer, comme à vol d'oiseau, notre sujet, à l'embrasser dans ce qu'il offre de plus général, et à nous placer dans la situation la plus avantageuse pour l'etude comparative des détails. ${ }^{116}$

For Geoffroy, then, the principle of connections was of major philosophical import. In his view, it was the only way to put into practice, fully and without restriction, that grand doctrine, now called "theory of analogues", which teaches the unity of composition of all vertebrate animals. Without the principle of connections, Geoffroy maintained, comparative anatomy would lack the means for an all-embracing, general application of this doctrine. In comparative anatomy one might at best suggest a correspondence between a part of the leg of a horse and the hand of a man on the basis of resemblances between intermediary forms that allowed the anatomist to go, step by step, from one extreme to the other. But, what if intermediary forms were lacking, as in the case of the pectoral fin of a fish and the arm of a man? Then, the principle of connections was of crucial importance because it placed the anatomist in a position from which he could compare directly the most diverse forms. In fact:

il vous suffira de considérer l'homme, un ruminant, un oiseau, et un poisson osseux. Osez les comparer directement, et vous arriverez de plein saut à tout ce que l'anatomie peut vous fournir de plus général et de plus philosophique. ${ }^{117}$ 
What would be the fate of an anatomist who continued to do without the principle of connections? Geoffroy had no doubts about it. Like an explorer without a compass, who was forced to follow the coast, the anatomist would have to embark on a long and difficult voyage: he could only compare different organs by passing through a chain of intermediary forms. The principle of connections thus was like a compass which put an anatomist in the position to draw together distant points. Geoffroy also made it clear that, in using this compass, anatomists would have to leave man as their traditional point of departure. That is, in studying connections, one should not give priority to any particular anatomy. Organs had to be studied first in those forms in which they reached a maximum of development, as for example the wishbone in birds, or the sternum in the tortoise. There, we might say, the compass of connections worked without any declination.

\section{Conflicting abstractions}

It was not only the author of the Philosophie anatomique who spoke of a new era in the history of anatomy. Geoffroy's contemporaries likewise perceived in his work a new, more philosophical approach that was worth following. As a matter of fact, since the publication of his anatomical memoirs in 1807, Geoffroy's position in the scientific community had already undergone significant change. While he had had no more to boast of than his professorship at the Muséum upon his return from Egypt, by 1807 he had gained immediate recognition for his work with his election as a member of the Institut de France and, one year later, with his appointment as a professor of zoology at the Faculte des Sciences of the Imperial University. ${ }^{118}$

Indeed, at the time that the Philosophie anatomique appeared, Geoffroy had become a leading member of the scientific community with several enthousiastic followers. ${ }^{119}$ Even Cuvier initially shared the enthousiasm for Geoffroy's work, although in his reaction to the Philosophie anatomique he also showed skepticism. That is, he carefully distinguished the facts that the book contained, which would "always remain a precious acquisition for science", from the more theoretical considerations, which were obviously doubtful in his view. ${ }^{120}$ While Cuvier's functionalist and Geoffroy's philosophical anatomy thus were more or less in harmonious accord when the Philosophie anatomique was published, the situation had completely changed by the end of the 1820 s. In the intervening years the writings of Cuvier and Geoffroy had begun to reveal a conflict that would eventually culminate in a famous and acrimonious debate before the Académie des sciences. ${ }^{121}$ 
We have seen that Cuvier ultimately founded his own natural system in zoology on four embranchements which, in his view, were completely distinct. However, in their attempts to establish analogies between organs, Geoffroy and others began to extend their research not only to different embranchements, but also to comparisons between embranchements, thus suggesting that the search for unity of composition might even eliminate the gaps between Cuvier's four distinct plans. Moreover, in 1822, Geoffroy published a second volume of his Philosophie anatomique devoted to so-called human monstrosities. This work, in fact, was only the beginning of a new line of research in which Geoffroy further extended unity of composition to a partly experimental study of animal malformations. Geoffroy, then, attempted to show that malformations were the result of an excessive or defective development of parts that were always present, whereby he explained these phenomena, in line with his earlier Egyptian speculations, in terms of a disturbed embryological development under the influence of some extraneous cause. All this, finally, suggested the idea to him that different forms of life might have been the result of a gradual evolution due to the modifying power of a changing environment. Thus, in his view, unity of composition also came to imply common descent. ${ }^{122}$

Although Cuvier almost never openly reacted to Geoffroy's ideas, his pronouncements clearly showed a growing uneasiness about what he considered to be excesses of speculative thought. ${ }^{123}$ Both the idea of an all-embracing unity of type and the idea of evolution he evidently considered ridiculous speculations associated, in his view, with the objectionable romantic Naturphilosophie popular among German naturalists. But as Appel points out, for Cuvier there were other matters of concern as well. Faced with challenges to his authority in the Académie des Sciences and with the continuous threat of political unstability in France, a threat which in his view would only be reinforced by romantic thought, Cuvier began increasingly to resist speculative and controversial ideas. ${ }^{124}$

\section{How to conceive of types and laws?}

Thus, as Cuvier and Geoffroy found themselves ever more divided, Cuvier increasingly emphasized the importance of facts against the vanity of theoretical speculation, a point which indeed was already clearly implied in his comments on the Philosophie anatomique. In 1828, when Cuvier published the first volume of a major taxonomic work on fish, he proclaimed in the very first sentence that natural history was a science of facts. ${ }^{125}$ Geoffroy, on the other hand, made it perfectly clear that in his view a naturalist should look beyond the facts. Anatomy, as he said: 
... fut longtemps descriptive et particulière; rien ne l'arrêttera dans sa tendance pour devenir générale et philosophique. ${ }^{126}$

Yet what was involved in this conflict was more, of course, than facts against theories. Cuvier, it is true, considered natural history to be pre-eminently a science of observation. But he too sought to generalize his observations into laws governing the phenomena of animal organization. No less than with facts, Cuvier was preoccupied with order. ${ }^{127}$ Indeed, in his earlier mentioned article on "Nature", Cuvier attested to his conception of order in a most explicit, not to say polemical, way. ${ }^{128}$ Evidently, God's creations were necessarily subjected to the "conditions of existence" since the existence of a living being would be impossible without a co-ordination of structures to fulfill its needs. But there were philosophers, Cuvier observed, who also wished to subject animal form to doctrines like the "chain of being" or "unity of composition". Such doctrines, however, imposed limits on creation that were imaginary and completely unjustified. Why should the Creator have followed laws which needlessly fettered His activity? Some years later, Geoffroy took the opportunity to respond to Cuvier's argument in his own article on "Nature", published in the Encyclopédie moderne. ${ }^{129}$ Had Cuvier, so he asked, not unjustly confused a matter of faith with conclusions of a scientific nature? Laws of nature had to be discovered and not to be invented. Geoffroy, then, made it clear that unity of composition was a demonstrated law which might even be compared to such general laws of nature as the principle of universal gravitation.

Thus, it is clear that, Cuvier's insistence on facts notwithstanding, both $\mathrm{Cu}$ vier and Geoffroy sought to create particular abstractions. Each in their own way obviously believed that in natural history one ought to ascend from particularities. Revealing in this respect is the way in which Cuvier presented the facts in his courses on comparative anatomy. As we have seen, Cuvier organized his presentation starting from the functions exercised by the animal body. In discussing these functions, he grouped those animals together in which these functions were exercised in the same way, that is, which resembled each other in the majority of their organs. In other words, instead of teaching natural history by referring to different animals one after the other, Cuvier had decided to compare functional systems in classes of animals that were arranged in conformity to their organization. ${ }^{130}$ Thus it was possible, as he said, to "elevate" the propositions of his science to the greatest possible generality. Geoffroy, as we have seen, found in the search for analogies his own way to save natural history from what he called a predilection for details. Aiming at a "bird's-eye view" of his subject, he persistently sought to create a point of view that would be as general as possible. ${ }^{131}$ 
No doubt, the way in which Cuvier and Geoffroy actually shaped their abstractions revealed very different concerns. ${ }^{132}$ Cuvier, to be sure, did not deny the existence of analogies between organs in different forms of life, but the study of these analogies had to be subordinated, in his view, to the principle of "conditions of existence". This was, as he said:

... le vrai principe philosophique d'ou découlent les possibilités de certaines ressemblances et l'impossibilité de certaines autres. ${ }^{133}$

Thus, according to Cuvier, the necessary functional relations between organs were the only true foundation for the laws of animal organization. These laws constituted distinct and immutable zoological types in which the search for analogies obviously found its limits. For Geoffroy, on the other hand, the allembracing unity of type was the true base of natural history whereby, in his confrontations with Cuvier, he especially emphasized the practical utility of the principle of connections. ${ }^{134}$ In his own words, this principle was the "instrument" which made visible the true "philosophical resemblances" between organs, resemblances that were so often masked by apparent dissimilarities due to variations in form and function. Thanks to this instrument, a naturalist could trace the universal laws of animal structure in the labyrinth of forms.

\section{Natural history transformed?}

In the foregoing chapter I have introduced the transformation of natural history as a theme that often recurs in the work of historians of biology and that figures large in Foucault's archaeological analysis. I have subsequently focused on the history of zoological classification in France, because this history is obviously relevant if we want to understand what happened in natural history at the end of the eighteenth century. In what sense, then, was natural history transformed by naturalists like Cuvier and Geoffroy? No doubt the article of 1795 , in which both these naturalists proposed a new way to classify the Mammals, indicated a more general urge to reform: the usual, artificial systems of classification, in which animals were arranged on the basis of a few salient characteristics, should be replaced by a system that would be genuinely natural. Cuvier's subsequent attempts to found a zoological system on the laws of animal organization were indeed accepted by most naturalists as important steps toward the realization of this end. Geoffroy, on the other hand, grew more and more convinced that a natural system was impossible to attain. In natural history, he wrote in 1829 , there was something more important than classifications. ${ }^{135}$ The 
time had come for philosophical studies, like his own in comparative anatomy.

Thus were introduced, through the work of both Cuvier and Geoffroy, new practices and theoretical concerns which, in the early nineteenth century, changed the way in which animal form was studied and conceived. But as Farber has pointed out in his study of nineteenth-century ornithology, the more traditional concern with describing and naming of genera and species on the basis of variations in external characteristics, by no means disappeared in the nineteenth century. ${ }^{136}$ On the contrary, the classification of an ever increasing number of specimens into species and genera remained the principal occupation of many naturalists, whose activities gave rise to the emergence of several separate disciplines like ornithology, ichthyology, entomology, etc.

What we see in Farber's picture of the transformation of natural history is not a general shift from one kind of interest to another, but a more complex pattern of change: on the one hand, a new interest in the study of animal form whereby a comparative anatomy was made the foundation of a general conception of a natural system on the level of zoological classes and orders and, on the other hand, a continuing interest in identification and nomenclature on the level of species and genera. This picture agrees, indeed, with Daudin's observation that in zoology the higher taxonomic divisions have been established by means that were different and largely independent from those which led to the exact determination of units lower in the taxonomic hierarchy. ${ }^{137}$

From the foregoing we may conclude that Foucault's picture of a complete rupture which brought natural history to a close is a too simple notion of what happened at the turn of the eighteenth century. This is not to deny, however, that from the end of the eighteenth century naturalists began to conceive of problems of classification from new, more theoretically inspired points of view. It is in the light of this development that Foucault speaks of the emergence of a radically different, so-called, modern episteme which embodied new rules of what might count as a true, natural classification. Seen from a Latourian perspective, however, the credibility of a classification will not depend on particular rules, but on the number and the strength of the linkages by which a classification is tied to a variety of statements, things and phenomena. Indeed, as we shall see in the next chapter, to understand how naturalists like Cuvier and Geoffroy succeeded in transforming the classifications of eighteenth century naturalists, we need not refer to discontinuities in forms of thought, but to ways in which networks of statements, things and phenomena were continually extended. 


\section{References}

1. Daudin, $1926 \mathrm{~b}$, chapter 2 , p. 140.

2. Outram, 1984, chapter 1 .

3. Ibid., p. 28.

4. Ibid., chapter 2.

5. Cuvier, 1858, pp. 172 and 227.

6. Tbid., p. 71 .

7. Ibid., pp. 71-72.

8. Ibid., pp. 119 and 131-134.

9. Ibid., pp. 73-74.

10. Coleman, 1964, p. 24.

11. Daudin, 1926b, chapter 1, pp. 57-60.

12. Cuvier, 1858, pp. 79-81,136-138,144, 203-204, 208, $209,224$.

13. Ibid., p. 72.

14. Ibid., pp. 178-179.

15. Ibid., p. 198-199.

16. Ibid., pp. 134-136, 247 and 261 .

17. Daudin, 1926b, chapter 8, pp. 17-18.

18. Ibid., chapter 8, pp. 19-20.

19. Tbid., chapter 1, pp. 56-57.

20. Ibid., chapter 1, p. 57; and chapter 3, pp. 224-226.

21. Cuvier, 1795a.

22. Chapter IV, p. 111.

23. Daudin, 1926b, chapter 8, pp. 20-35, especially pp. 25-26.

24. Cuvier, 1795a, p. 386.

25. Ibid., pp. 388-389.

26. Daudin, 1926b, chapter 8, p. 49.

27. Cuvier, 1795 b, p. 434.

28. Coleman, 1964, p. 79.

29. Daudin, 1926 b, chapter 8 , pp. 50-51.

30. Cuvier, 1795a, p. 395.

31. Daudin, 1926b, chapter 8, p. 30.

32. Outram, 1984, p. 54.

33. Daudin, 1926b, chapter 1, p. 31.

34. Appel, 1987, pp. 38-39.

35. Flourens, 1856, I, p. 182. See also Appel, 1987, p. 39.

36. Appel, 1987, p. 39. See also Outram, 1984, chapters 2 and 3.

37. Flourens, 1856, I, p. 185. See also Outram, 1984, p. 61.

38. Outram, 1984, pp. 62-63. 
39. Appel, 1987, chapter 3.

40. Ibid, p. 42. See also Outram, 1984, pp. 125-126.

41. Outram, 1984, chapter 4.

42. Appel, 1987, pp. 59-68.

43. Ibid., p. 40.

44. Coleman, 1964, p. 31.

45. Cuvier, 1800 , I, pp. i-vi and 1-9.

46. Ibid., p. v.

47. Ibid., p. iii.

48. Ibid., pp. v-vi

49. Ibid., pp. i-ii. See also pp. ix-xviii.

50. Ibid., pp. iv and 9. See also Cuvier, 1817, pp. 3-6.

51. Ibid., pp. 1-45.

52. Ibid., pp. 45-46.

53. Ibid., p. 47.

54. Ibid., pp. 47-58.

55. Daudin, $1926 \mathrm{~b}$, chapter 8 , p. 58.

56. Coleman, 1964, chapter 5; Daudin, 1926b, chapter 8, pp. 62-68.

57. Quoted by Daudin from Cuvier's Recherches sur les ossements fossiles (1825). Daudin, 1926 b, chapter 8, p. 64 .

58. Ibid., chapter 8, p. 66.

59. Coleman, 1964, p. 120.

60. Cuvier, 1800 , I, pp. xviii-xix.

61. Appel, 1987, p. 44.

62. Coleman, 1964, p. 13.

63. Cuvier, 1817 , pp. vi-vii.

64. Cuvier, 1800, I, p. 62. See also Cuvier, 1817, pp. xvi and 10 .

65. Cuvier, 1812, pp. 75-76.

66. Ibid., p. 76 .

67. Daudin, 1926b, chapter 9, pp. 97-101.

68. Coleman, 1964, pp. 90-91.

69. See for example Cuvier, 1817, p. 21. See also Outram, 1986; pp. 361-362.

70. Cuvier, 1812, p. 83.

71. Daudin, 1926b, chapter 9.

72. Cuvier, 1800, I, p. 58.

73. Daudin, 1926a, pp. 159-173.

74. Ibid., pp. 184-185.

75. Ibid., p. 186; Daudin 1926b, chapter 9, pp. 76-87.

76. Cuvier, 1800 , I, p. 60.

77. Cuvier, 1812, p. 79. 
78. Cuvier, 1817 , p. $x x i$.

79. Cuvier, 1825, pp. 261-268.

80. Appel, 1987, pp. 19-22; I(sidore) Geoffroy Saint-Hilaire, 1847, chapter 1.

81. Appel, 1987, pp 29-34; I(sidore) Geoffroy Saint-Hilaire, 1847, chapter 2.

82. Daudin, 1926 b, chapter 1, p. 31.

83. Appel, 1987, pp. 27-28.

84. Daudin, 1926b, chapter 1, pp. 49-51; chapter 9, pp. 71-73.

85. Chapter I, p. 29.

86. Daudin, $1926 \mathrm{~b}$, chapter 9, pp. 73-75.

87. Quoted by Daudin from Geoffroy"s "Mémoire sur les rapports naturels des MakisLemur L. et description d'une espèce nouvelle de Mammifere". Ibid., chapter 9, p. 74.

88. Appel, 1987, pp. 28-29; I(sidore) Geoffroy Saint-Hilaire, 1847, pp. $71-73$ and 133-135.

89. Quoted in I(sidore) Geoffroy Saint-Hilaire, 1847, p. 134.

90. Tbid., pp. 134-135.

91. Daudin, $1926 \mathrm{~b}$, chapter 8 , pp. $40-46$.

92. Ibid., chapter 8, pp. 31-35.

93. Appel, 1987, pp. 22-24.

94. Ibid., pp. 72-81.

95. Ibid., p. 76.

96. Ibid., p. 78.

97. Ibid., p. 72.

98. Ibid., p. 83.

99. Geoffroy, 1802 .

100. Ibid., p. 394.

101. Appel, 1987, p. 86.

102. Ibid., pp. 69-70.

103. Ibid., p. 70.

104. Ibid., p. 85. See for a general description of the content of these memoirs: Appel, 1987, pp. 86-89; I(sidore) Geoffroy Saint-Hilaire, 1847, pp. 148-162

105. Geoffroy, $1807 \mathrm{a}$.

106. See also: Geoffroy, $1807 \mathrm{~b}, \mathrm{pp} .87-89$.

107. Geoffroy, 1807a, p. 370 .

108. Geoffroy, $1807 \mathrm{~b}$.

109. Appel, 1987, p. 70.

110. Ibid, p. 70 .

111. Geoffroy, 1807 c, p. 344.

112. Appel, 1987, p. 91.

113. Ibid., p.93.

114. Geoffroy, 1818, p. xxi. 
115. Ibid., pp. xxii-xxiil.

116. Ibid. pp. xxvii-xxviii.

117. Ibid., p. xxxvilit.

118. Appel, 1987, p. 92.

119. Ibid., pp.101-104.

120. Ibid., p. 101.

121. I will not discuss this debate here. See Appel for an elaborate and very interesting account. Ibid., chapter 5 and 6.

122. See for Geoffroy"s ideas on evolution also Laurent, 1977; and Corsi, 1988, chapter 8.

123. Cuvier"s earlier mentioned article "Nature" in the Dictionnaire des sciences naturelles is illuminating in this respect. See Cuvier, 1825.

124. See also Outram, 1984 , chapter 6.

125. Appel, 1987, p. 105.

126. Geoffroy, 1830b, p. 188. See also I(sidore) Geoffroy Saint-Hilaire, 1847, pp. 125-126.

127. Appel, 1987, pp. 46-59. See also Coleman, 1964, pp. 10-17; and Outram, 1984, pp. 91-92 and 128-129.

128. Cuvier, 1825. See also Appel, 1987, pp. 136-138.

129. Geoffroy, 1830a. See also Appel, 1987, pp. 140-141.

130. Outram, 1984, pp. 181-182. See also Coleman, 1964, pp. 76-77.

131. See also Laurent, 1977, pp. 44-48.

132. Appel, 1987, pp. 172-173. See also Russell, 1916, p. 75.

133. Cuvier, 1830 , p. 66. See also Appel. Ibid., p. 148.

134. Appel, 1987, p. 149. See also Laurent, 1977, p. 47.

135. I(sidore) Geoffroy Saint-Hilaire, 1847, p. 331 .

136. Farber, 1982a. See also Farber, $1982 \mathrm{~b}$ and $1982 \mathrm{c}$.

137. Daudin, 1926b, "Avant propos",p. iv. 
CHAPTER VI

\section{THE RELATIVTTY OF CHANGE}

\section{Foucault: the end of natural history}

The history presented in the foregoing chapters is only one of the stories that can be told about the transformation of natural history. As I indicated in the Introduction, we may add to this story accounts like those of Foucaull, or a of Latourian observer, in which the reader is asked to look beyond the experiences, practices, ambitions and conceptions of naturalists for a deeper understanding of what was going on. Foucault is indeed very explicit on this point. In his eyes, a history on the level of "what historians say", like the foregoing history of zoological classification, is no more than a history of a surface movement. If we really want to know what happened in natural history at the end of the eighteenth century, we have to analyse this history on the level of underlying forms of knowledge. Then, we will see that what appeared in the debates on a natural system as a movement of shifting judgements and opinions was in fact a sign of a deeper and fundamental rupture. What really happened, according to Foucault, was the emergence of a new mode of thought, a modern episteme, which constituted a new mode of being and so "fragmented in depth" the great table of natural history. In his analysis of the fate of natural history on the lavel of these archuedlogical events, Foucault especially focused on the work of one man, namely, the French naturalist George Cuvier.'

What was the nature of the modifications that so fundamentally affected the study of living beings on the threshold of the nineteenth century? We have seen that in terms of Foucault's analysis, it was the aim of classical natural history to represent the visible structures of beings in such a way that these beings might be ordered according to their identities and differences. In fact, such a representation was nothing more than a selection, from the totality of visible structures of plants or animals, of those elements that were deemed appropriate for representing identities and differences. Such a representation, then, was established by a relation of "the visible to itself". However, from the end of the eighteenth century onward, naturalists began to base the choice of characteristics indicating relations between the forms of life, upon a principle that lays outside the domain of the visible. From then on, the choice of such indicative 
characteristics was justified with reference to the "coherent totality of organic structure". In other words, these characteristics merely became visible points in a web of hidden, functional relations between organs.

According to Foucault, all this was of fundamental importance because through the appeal to the peculiarities of organic structure, the notion of "life" became indispensible to the ordering of beings. Now, the dividing line between the living and the non-living was no longer one characteristic among many others, but defined the very space for a classification. Thus it was that in those crucial years the traditional distinction between the three kingdoms - plants, animals and minerals - was superseded by the opposition of only two: organic and inorganic. But Foucault again regards this change merely as a surface effect of a much more important archaeological event in which the possibility of a biology came into being and the era of natural history was brought to a close.

De Jussieu is mentioned by Foucault as one of the naturalists whose work showed the first signs of this event. De Jussieu not only upheld a principle of subordination of characteristics, but also explicitly pointed out that particular characteristics of plants often appeared to be related to each other, which suggested the possibility of dividing the whole vegetable kingdom into a few comprehensive classes corresponding to different modes of organization. In Foucault's view, however, it was Cuvier who in his zoological work definitively established a relation between the principle of subordination and the peculiarities of the various organic structural plans of living beings. Thus, in The Order of Things, Foucault tries to make clear, in his own and intriguing way, that Cuvier's conceptions and techniques indeed marked a crucial, archaeological event.

In his analysis, Foucault first of all emphasizes that in Cuvier's thought functions were all-important. That is, Cuvier's work was based essentially on the idea that the existence of an animal depends on functions - such as circulation, respiration, and sensation - which are relatively few in number, but which are performed by organs that may be very different in different groups of animals. Organs, then, might resemble each other in the effects they produce, like lungs and gills that both serve for respiration, without sharing any identical element. Thus, from Cuvier's point of view, it became possible to relate elements to each other, not because there was some visible identity, but because there was a hidden, functional resemblance. Moreover, it was also from this functional point of view that it became possible to understand why some organs always implied the presence of some others, as in the case of the observed coexistence between a particular conformation of the digestive system and the form of the teeth and the limbs of an animal. That is, in describing an animal Cuvier was dealing not with independent variables - the number and form of teeth, nails, etc. but with a functional whole in which the conformation of the most important organs determines the plan upon which a certain animal is built. 
Why is it that in Foucault's analysis the work of Cuvier exemplifies a discontinuity in the history of thought, a sudden movement in which the table of natural history was opened up in depth? That is because in Cuvier's work the homogeneous space of visible identities and differences was replaced by a space in which identities and differences were no longer on the same level. What drew animals together in Cuvier"s zoological classification was the interrelated way in which the various functions were performed, whereby animals in which the main internal organs had a similar structure constituted the most general taxonomic groups of his system. Thus, to establish identities a naturalist had, as Foucault puts it, to penetrate into the organism's "inner darkness", into that essential dimension of its life that "eludes perception". What, on the other hand, divided animals in Cuvier's system into less general groups were those characteristics that were more variable and visible, just because they were taken from accessory, that is, less important and more superficial parts. So; the analysis of differences took place against a background of identities that were deeper and that no longer were part of that classical "unitary field of visibility and order". Hence Foucault's conclusion that, from Cuvier onward, the possibility of classification arose from the depths of life, in a movement which, at the same time, established the possibility of a biology.

In relation to Cuvier's work, Foucault also discusses two techniques which appeared upon the dissociation of the space of natural history. First, there was the constitution of a comparative anatomy, which obviously implied more than just a deepening of the descriptive techniques employed in the classical age. Foucault speaks of a new space in which animals were cut up, especially to reveal the patterns according to which organs are mutually related to each other and so, to disclose broad structural resemblances between the forms of life that would otherwise have remained invisible under the teeming profusion of visible differences. Connected to this comparative anatomy was another technique in which the necessary correlations between the various parts of an animal were invoked to establish that the form of some of its parts indeed indicated the structure of most others.

In creating these techniques, Cuvier shattered, as Foucault points out, not only the homogeneity of the tabular space of identities and differences, but also its continuity. Naturalists who in the seventeenth and eighteenth century juxtaposed all beings in a table, did so on the assumption that these beings were connected to each other both through identities and differences. That is, forms of life might be different but never distinct, because nature always passed from one form to the other by almost imperceptable degrees. Hence, the traditional image of a continuous chain of being which was generally accepted in the eighteenth century. From Cuvier's work, however, a totally different view emerged. 
Now, a difference between forms always multiplied itself, since one difference necessarily implied all kinds of other differences diffused throughout the organism. The difference in the colour of the blood between red-blooded and whiteblooded animals was thus correlated with many other differences, related to the skeleton, the nervous system, the circulation, the digestive system, etc., isolating the first group of animals completely from the second.

Cuvier's recomposed space of identities and differences is described by Foucault as a space in which a living being must be a coherent whole in order to maintain its life, that is; a space in which beings must group themselves around "nuclei of coherence" that were totally distinct from one another. Nineteenthcentury nature, according to Foucault, was discontinuous exactly in so far it was alive. But Foucault immediately adds to this conclusion that, in the view of $\mathrm{Cu}-$ vier, the maintenance of life also depended on an unexpected, but fundamental continuity. In fact, Cuvier's work was permeated by the idea that a living being, just because it is alive, is continuously subjected to all that surrounds it: the air it breathes, the water it drinks, the food it absorbs. Ruminants, then, are distinct from Rodents, differ in kinds of dentition, in their digestive systems, in their extremities and nails, because they have different modes of life, depend on different kinds of food. At the background of Cuvier's thought there was always this conception of a continuous relation between forms of life and conditions of existence and in this respect, too, his thought implied a fundamental break. Whereas the classical table had been filled with an endless continuity of forms, Cuvier bound the possibilities of form, not only to the necessities of an interior, anatomical coherence, but also to an exterior reality of widely divergent conditions of existence.

Indeed, from the depth of Foucault's archaeological analysis, Cuvier appears as a most rewarding subject for anyone with an interest in genuine revolutions of thought. Here we have the story of a man who, through his concern with the phenomena of life and their relation to a history of divergent conditions of existence, definitely tore apart the homogeneous, continuous and timeless space of natural history. A man who created the conditions which made possible not only the idea of a science of biology, but also the idea of a history of nature. As I have indicated in the Introduction, Foucault is by no means the only one who has traced the origin of a modern science of life to the early nineteenth century, and his work has inspired some authors to expand his archeeological analysis to developments in mineralogy and physiology. So we may indeed ask ourselves if Latour, in his infectuous enthousiasm for the way in which scientists continually attempt to extend networks of statements, things and phenomena, is not ignoring the very point which in Foucault's archaeology is all-important: the occurence from time to time of far-reaching qualitative changes in man's conceptions of the world. 
Of course, in the seventeenth and eighteenth century, naturalists were very successful in their attempts to extend a network of botanical and zoological classifications and a Latourian account of what made for their success no doubt puts things in a fascinating light. However, what happened in the eighteenth century was more than an extension of the number of plants and animals that were being tied together in systems of classification. What changed, that is, was also the way in which those plants and animals were being tied together. How to understand those changes in the structure, in the logic of systems of classification? From a Foucauldian point of view, it is clear that we should study such changes on the level of thought. ${ }^{2}$ But what about a Latourian observer? How to account for the appearance of enigmatic, Foucauldian changes in the logic of classification in terms of a Latourian sociologics?

\section{Latour on relativity}

The question of a Latourian account of Foucauldian discontinuities in the history of thought is all the more interesting because the clue to an answer can be found in an article by Latour in which he presents a so-called relativistic account of Einstein's relativity. ${ }^{3}$ Could one think of a better example of a revolution of thought than Einstein's relativity theory? Latour presents his readers with another interpretation of what Einstein did. What Einstein hoped to avoid with relativity was relativism: if we simply accept that actors who are "delegated" to different spatial and temporal frames of reference have different, subjective points of view, then it becomes impossible to combine their observations. With his relativity Einstein created relations between frames of reference, in such a way that any observation of any actor could contribute to the credibility of one and the same description of one and the same event. As Latour sees it, for Einstein the question was not how to revolutionize our thinking, but how to conserve the laws of nature.

Latour's account is based on a work in which Einstein explains relativity in a semi-popular way, and which, as Latour points out, is of great interest because in this text the attention is focused on the very operations which allow an "enunciator" to align the observations of actors delegated to different spatial and temporal frames. How, for example, to relate the observation of an event by someone in a train and by someone on the embankment? First of all, the delegated observers must be thoroughly disciplined. What is expected from them is neither more nor less than an exact recording of the hands of watches and the notches of rulers. Thus, as a first step in the attempts of the enunciator to relate the observations of different actors, these actors are equipped with clocks and 
rulers which allow them to produce coded inscriptions. But before the reports sent back by the delegated actors can be combined into one single description of one and the same event, these reports first have to be "retranscribed". In Einstein's special theory of relativity this is done by means of the so-called Lorenz transformation, which allows the enunciator freely to move from one frame of reference to another without, as Latour puts it, "having to lose, in the jump, the documents gathered by the delegated actors".

It is not difficult to recognize in this account some of the essential elements of Latour's argument in Science in Action. There, for example, cartography likewise is described as the result of the accumulation and combination of coded observations gathered by disciplined travellers with the help of instruments like compasses, rulers and clocks. But what becomes especially clear in the story of Einstein is that the accumulation and combination of observations always involves a transformation. Latour even refers to Einstein as someone who was obsessed with "transporting information through transformations without deformation". Indeed, the transformation of information is central in the activity of scientists. It is always involved when some details are abstracted from an observation which render the result mobile, stable and combinable. Einstein equipped his observers with clocks and rulers and in doing so he turned into insignificant details the view from, or the colour of the train. Linnaeus prescribed how naturalists ought to describe plants and animals in a methodical way and so, he likewise rendered superfluous information on odours, uses or localities.

In these abstracting activities there is not only something lost, but also something gained. Only by equipping his observers with clocks and rulers, could Einstein create for himself the possibility to combine different observations in one reversible movement from one frame of reference to the other. And only by forcing naturalists to describe plants and animals methodically, did it become possible to combine any plant or animal, from any part of the world, into one comprehensive system. Only by binding, then, the abstracting activities of any observer to a chain of metrological procedures, observations could be kept equivalent. In the eyes of a Latourian observer, Einstein's revolution was neither more nor less than an additional step in this process, and in this respect his work was not different from that of a Linnaeus.

When even Einstein's "revolutionary" work is presented by Latour as an outstanding example of the effort of scientists to extend networks of statements, things and phenomena, is he not ignoring the occurrence in the history of thought of far-reaching qualitative changes in man's conceptions of the world? After all, was Einstein not the man who shattered our most common notions of space and time? Latour's answer is that Einstein did not present us with a break from usual ways of thinking, but with a choice between two ills, that is, "either 
we maintain absolute space and time and the laws of nature become different in different places; or we maintain the equivalence of the laws of nature and we discard absolute space and time". Why, then, did Einstein break with some of our most cherished beliefs, the notions of absolute space and time? Because it was only in this way that something more important could be conserved, namely, the possibility to extend as far as possible a network connecting different points of view. What Einstein sought, according to Latour, was not a revolution, but "the weakest point that should give way for everything else to be maintained".

\section{How to align different points of view?}

What clues are there in the foregoing for an account of Foucauldian discontinuities in terms of a Latourian sociologics? Evidently, the extension of networks is not all that Latour is talking about. In his account of what scientists do, there is also room for changing conceptions of the world, and for epistemological concerns. However, whereas Foucault's archaeology gives priority to such changes and concerns over the daily activities of scientists, for Latour it is quite the other way around. In the latter's view, changing conceptions and epistemological concerns simply are a consequence of the "lowly work" of building and relating networks. Anybody who persistently seeks to extend a network, cannot but sacrifice from time to time a usual way of thinking or a favourite epistemological ideal. So Einstein was willing to give up absolute space and time.

Let us now go back to natural history and again confront Foucault's analysis with that of a Latourian observer. In part one I concluded that in both a Latourian and a Foucauldian account of natural history the analysis is focused on the emergence of a framework that allowed naturalists to move freely from one plant or animal to another. By now we can say that, seen from a Latourian perspective, the creation of such a framework involved changes that were quantitative as well as qualitative. That is, the mobility, stability and combinability of beings could only be enhanced by a series of transformations in which some details were abstracted from a plant or animal at the cost of others. Only thus did it become possible to relate plants or animals in an all-embracing system of classification. What was maintained in this process and what was lost, of course varied from one system to the next. So, we may conceive of any system of classification as a frame of reference, characterized by some dominating points of view.

We have seen that natural history in the eighteenth century was marked by a battle in which the relative merit of different systems was the subject of continuous debate. Those who conceived of a system of classification as nothing more than an instrument to serve a practical purpose, could in principle accept 
any point of view which allowed a convenient classification. However, such relativism was generally rejected by those naturalists for whom the search for a system of classification was a true scientific endeavour. Their ideal was a natural system, and implicated in the realization of this ideal was a tendency towards either absolutism or relativity. In the first case, one adhered in classifying to one "essential" point of view. But we have seen that there was a limit to this absolutism even in the work of a Linnaeus. He who simply and solely relied on pistils and stamen had, by his own admission, created an artificial system. A natural system would become possible only by taking into consideration a multitude of characteristics, and that is why Linnaeus defined each of his natural genera in terms of a combination of characteristics taken from the system of fructification. ${ }^{4}$ Of course, such a relativity of points of view was much more explicitly pursued by those naturalists who criticized Linnaeus for not taking all parts into account, as is clearly illustrated by the work of Adanson. ${ }^{5} \mathrm{He}$ showed that it was possible to devise no less than sixty-five artificial systems of classification, each based on one particular attribute of plants, providing him with all the points of view that were combined in his own "natural method".

Indeed, notions of relativity were also manifest in the French debate on classification in zoology. As we have seen, naturalist-nomenclators, who ruled the practice of classification from their cabinets, were criticized by physiciananatomists like Daubenton and Vicq-d'Azyr for being overly concerned with the surface of things. Thus, Daubenton upheld the view that naturalists first of all had to appreciate the integrity of the animal as a whole. Instead of describing and comparing animal forms on the basis of only a few external parts, one had to make complete descriptions, including all the important organs, internal as well as external. Vicq-d'Azyr expressed similar feelings when he noted the distance between a natural history in which only external parts were considered, and an anatomy that was restricted to the study of internal parts.

Thus, when Cuvier, at the end of the eighteenth century, proposed a new approach to the classification of animals, seeking to justify classes and orders with reference to the mutual dependencies of the animal economy, he moved in a direction that had already been hinted at by some distinguished naturalists. Like Daubenton and Vicq-d'Azyr, he took it for granted that in classifying animals one had to consider both the external and internal parts. That is, like them, he assumed that the credibility of a classification depended on a multiplicity of points of view. But, how to relate those points of view in such a way that the observations of a naturalist might be aligned with those of an anatomist or physiologist? This was the very problem that Cuvier attempted to solve in his early memoirs on Mammals and Worms. Thus, in the first of these two memoits, he and Geoffroy did not deny the possibility of a rigorous definition of 
genera, orders and classes in terms of a few indicative characteristics, a possibility which was, as they observed, the basis of any artificial system of classification. However, they wished to inform this practice with knowledge of the "well-related" system of the animal economy, which could serve them as a basis to assess the relative value of characteristics in creating a natural system of classification. ${ }^{6}$

In theory, it is true, Cuvier based his zoological classifications on characteristics taken only from the physiologically most important organs, thus apparently accepting some privileged point of view. But he did so explicitly on the argument that this very point of view actually involved most others. In fact, in a system of classification, any indicative characteristic was acceptable in his view, insofar as it indicated the features of the animal organization as a whole. Thus, in his classification of the Worms, or so-called white-blooded animals, Cuvier referred to the mantle of the Molluscs as an indicative, external characteristic, not because he knew it to be physiologically important, but because it appeared to be constantly related to the conformation of the primary, internal organs of this class. ${ }^{7}$

We have seen that, in Foucault's view, it was Cuvier who definitely established a relation between a principle of subordination, whereby characteristics were ranked according to their taxonomic value, and a conception of animal organization, whereby the emphasis was laid upon the coherent totality of organic structure. But what Foucault really wishes to point out is that Cuvier thus freed the subordination of characteristics from its purely taxonomic function, and turned it into the foundation of a radically new, functional and hierarchical conception of organic structure. That is why, in Foucault's view, Cuvier's work led to an upheaval in natural history and implied a discontinuity in the history of thought.

But in this case, too, we might argue from a Latourian point of view, that for Cuvier the question was not how to revolutionize our thinking, but how to maintain, to conserve as many points of view as possible. Cuvier, then, did not free the subordination of characteristics from its taxonomic function. On the contrary, in his hands the principle of subordination became a means to tie together the traditional interests of naturalists and anatomists. As a naturalist, he wished to unite the multiplicity of beings into a rigid hierarchy of more and more comprehensive taxonomic groups, as an anatomist he sought to define those groups in such a way that they would neatly indicate all the important features of animal organization. ${ }^{8}$ We know how he succeeded: he indicated the most general groups of his system through those features of an animal which appeared to be highly correlated to the majority of other features and which thus, to use the words of Foucault, became "visible points" in a web of hidden, functional relations between organs. 
Foucault refers to Cuvier's comparative anatomy and to his establishment of correlations between parts as techniques which constituted a new space for the study of animal form. But it is clear that, in terms of Foucault's archaeological analysis; these techniques were part or consequence of a more fundamental event, that is, the dissociation of the space of natural history through the constitution of "life" as a new form of knowledge. In the eyes of a Latourian observer, however, these techniques did not reveal a sudden and radical change on the level of forms of thought, but were the very means through which Cuvier succeeded in tying together different, but long-standing points of view. Indeed, in the eighteenth century a concern with life and with the "animal economy" was part and parcel of the trade of anatomists and physiologists. ${ }^{9}$ But it was $\mathrm{Cu}-$ vier who managed to link this concern to the endeavour of naturalists by furnishing life with a particular kind of visibility. ${ }^{10}$

We have seen how Cuvier introduced comparative anatomy in his Leçons $d^{\prime}$ anatomie comparée as the outstanding means to bring to light the phenomena of life which, as he said, remained so largely invisible and hidden from our instruments. ${ }^{11}$ In his view, it was by comparing the different forms of animal organization that one could study the most palpable manifestations of life in a way that fully exploited the experiments of nature. Thus, by means of his comparative anatomy, Cuvier made visible how the different parts of the body affected each other in the animal economy, and it was this particular visibility of the correlations between parts which allowed him to establish anatomical laws as well as a natural system. Cuvier, then, succeeded in moving freely between different points of view because with his technique of correlation he added a minor innovation to the tools of a naturalist, an innovation which made it possible to establish, as Foucault has so aptly formulated it, "networks connecting any point in the body with any other".

However, as we may learn from Latour's account of Einstein's relativity, networks are never extended without cost. Indeed, to create for himself the possibility of combining different points of view, Cuvier introduced techniques which furnished animal life with a new visibility, and in so doing he also to some extent transformed the traditional practices and concerns of both naturalists, anatomists and physiologists. No doubt, anatomists and physiologists already had a long-standing interest in the animal economy, but in the eighteenth century they were concerned with vital forces and the localization of these forces in different parts of the body, rather than with animal organization and the mutual dependencies between organs. ${ }^{12}$ So Cuvier's work, in fact, strongly reinforced an interest in the phenomena of organization and in comparative anatomy as its proper science. 3 
Cuvier's work obviously also to some extent displaced the interests of naturalists. Already in his very first memoir on the Worms, Cuvier made it clear that shells, the pride of many collectors, were useless in classifying the animals with white blood for anyone who did not cling to old routines and studied the animals themselves. But that was not all. Faced with the impossibility of connecting the time-honoured group of white-blooded, or invertebrate animals with a few simple anatomical laws that would elevate the propositions of the science to the greatest possible generality, Cuvier ultimately completely discarded this group in the face of previous usages. As we have seen, the animal kingdom was now partitioned into four distinct plans. ${ }^{14}$ Thus, as the means of his comparative anatomy allowed him to establish increasingly firm correlations between parts as the basis of both anatomical laws and a natural system, Cuvier increasingly weakened one of the most cherished beliefs of naturalists, that is, the belief in a fundamental continuity of forms. ${ }^{15}$ In other words, Cuvier's hard work of building and relating networks was inevitably attended by a transformation of traditional modes of thought.

From a Latourian point of view, then, there is certainly no reason to deny Foucault's argument that Cuvier's work implied some far-reaching qualitative changes in naturalists's conceptions of the world. In several respects, Foucault's description of these changes is illuminating indeed. Foucault, however, invokes in addition an enigmatic great divide between a classical and a modern mode of thought as the fundamental condition which made it possible for these changes to occur, whereas, from a Latourian point of view, these changes can be very well explained by shifting the attention to the concrete means through which Cuvier created a divide between his system of classification and that of others. Cuvier, as we have seen, was neither the first, nor the only one, to see knowledge of both external and internal characteristics as a precondition for a true, natural system of classification. Why did he succeed while Vicq-d'Azyr, for example, failed? Was it, as Foucault suggests, because Vicq-d'Azyr's work modified the methods and the techniques of a classical taxonomy, but without refuting "its fundamental conditions of possibility"? ${ }^{16}$ That is, without escaping from the bounds of classical thought? There seems to be a much more mundane and plausible explanation. While, as an anatomist, Vicq-d'Azyr did indeed propose a new approach to the practice of classification, he nonetheless failed to find a means or tool through which anatomy and natural history could really be combined. In other words, what divided Cuvier and Vicq-d'Azyr was not a fundamental difference in modes of thought, but the way in which Cuvier succeeded in using the notion of correlations between parts as a technique to unite anatomical laws and a natural system into one durable whole. 


\section{A philosophical natural history}

Although Foucault, in his archaeological analysis of the transformation of natural history, focuses on the work of Cuvier, it is clear that his analysis should also hold for Geoffroy, because, just like Cuvier, Geoffroy sought to establish identities that lay beneath immediately visible forms. Whereas a Linnaean taxonomist considered forms as identical only insofar as the number, form, proportion and situation of immediately recognizable characteristics were the same, Geoffroy conceived of analogies between organs that might be as different as the hand of a man and the wing of a bat. In the eyes of Foucault, the work of Cuvier and Geoffroy offered different kind of solutions to the same problem: tracing organic identity on the basis of constants which are not immediately perceptible. That is, on the archaeological level, we find in their work the same transformation of the rules according to which objects of study were defined and concepts and theories were formed. ${ }^{17}$

But how can we define the relation between Cuvier's and Geoffroy's work from a Latourian point of view? In terms of a Latourian sociologics, we might say that Cuvier and Geoffroy followed a common rule, but it was not a rule which divided their work from that of earlier naturalists like Linnaeus or Buffon. On the contrary, it was a rule which all scientists follow at all times and with all means, namely: how to assemble and hold together as many allies as possible in order to maximize the credibility of statements. Thus we have seen how Linnaeus introduced standards, like the number, form, proportion and situation of parts, as a means which allowed him, not only to enhance the combinability of plants or animals in a system of classification, but also to keep equivalent the descriptions of many different observers. With Linnaeus's work, however, the debate on the credibility of systems did not end. Other naturalists were seeking other means to enhance the number and strength of the linkages between a rapidly increasing variety of forms. Thus Cuvier and Geoffroy introduced some new means which allowed them, each in their own way, to ascend from isolated observations, to combine everything on the highest level of generality. ${ }^{18}$ That is, if they chose to study hidden identities, they did so in order to extend a network of statements, things and phenomena.

Geoffroy's conception of science is very revealing in this respect. Much more explicitly than Cuvier, he stated as the aim of a true, "philosophical" natural history that one should raise one's abstractions to a point from which everything might be related to each other. Indeed, abstraction was for Geoffroy a way to establish links between unrelated domains and we might see his work as a typical example of what Latour has called the "obsession of theoreticians for easy transportation and rapid communication". ${ }^{19}$ Instead of separately conside- 
ring and naming the forefoot of a ruminant, a lion, a bat, a whale, etc., a naturalist should find a way to move reversibly from one organ to the other in order to establish "philosophical resemblances" between them. ${ }^{20}$

However, Geoffroy's philosophical obsession was clearly insufficient to hold together many different allies. His career nicely illustrates what we have seen earlier in the case of Buffon, namely, that the force of a philosophical natural history did not depend on some special features of thought, but on the concrete, practical means which lent this thought a particular credibility. Thus there is no reason for Goulven Laurent's surprise at the fact that Geoffroy pronounced the idea of unity of composition at the very beginning of his career and yet, much later, claimed that he got this idea only after many years of study. ${ }^{21}$ If we look at the words quoted by Laurent to substantiate this point, it appears that what Geoffroy was claiming was something rather different. And what he was really saying is very interesting in the light of my earlier remark. Geoffroy, that is, was pointing out that it was only after many years of study that he saw how to use two principles - that of analogues and of connections - as "means of investigation" which could serve him as "a guide, a practical instrument, a sort of compass" $^{\prime 22}$ In other words, the idea was indeed there from the beginning, but it remained a weak, speculative thought as long as it could not be linked up with a variety of forms. Geoffroy, then, succeeded in enhancing the credibility of his ideas only when the establishment of connections between parts offered him a means which allowed him to move freely between forms as different as a man, a bird and a fish. ${ }^{23}$

Thus we have seen how Geoffroy sought to establish more and more tenacious analogies between forms, even in those cases in which such analogies were most difficult to trace. He moved from rather obvious cases like the antlers and horns of ruminants to the connections between bones; from adult forms to the fetus, from normal development to malformations, from vertebrates to invertebrates. In other words, it was just because of his continual attempts to $e x-$ tend a network, that Geoffroy increasingly began to look behind immediately visible identities. Indeed, what Cuvier had been doing with regard to the notion of life, Geoffroy was doing with regard to the classical notion of analogy. Using the principle of connections as his principal tool, he furnished analogies between forms with a new and particular kind of visibility and so he, too, effected a transformation of established modes of thought. That is, a philosophical natural history might only be attained if naturalists were prepared to give up form and function as a guide in the search for relations between the variety of forms. 


\section{Conclusion}

In a recent article on Cuvier's work, Dorinda Outram has observed that in the literature Cuvier has been portrayed in two radically different ways. ${ }^{24}$ Coleman, for example, has identified him as an intellectual and political conservative who adopted an old-style, Aristotelian kind of teleology and who on those grounds was resistant to transformism. In marked contrast with this picture stands Foucault's interpretation, in which Cuvier is presented as a radical innovator who, his fixism notwithstanding, paved the way for Darwin's evolutionary theory. ${ }^{25}$ In her own analysis of Cuvier's work, Outram shows that neither view is justified. She places Cuvier's ideas in, what she calls their intellectual context and then shows that Cuvier "began to use ideas from many different specialties to change completely the notion of what was involved in natural history". In other words, Cuvier's characteristic mode of procedure was not that of radically breaking with existing ideas, but of "intellectual appropriation and a bold capacity for altering the relationships between different fields of knowledge". ${ }^{26}$

Outram's observations are of course very interesting in the light of my own Latourian account of Cuvier's work, because she too, emphasizes that Cuvier transformed natural history by relating various existing points of view: In terms of my Latourian analysis, we might say that Cuvier, like any scientist, was a conservative who in a continuous attempt to strengthen the credibility of his statements wished to maintain as many accepted beliefs as possible. Thus, to fortify his classifications in zoology, Cuvier not only built up an impressive collection of anatomical preparations, but he also attempted to incorporate in his project the points of view of naturalists, anatomists and physiologists. However, to align those different points of view, Cuvier also had to be an innovator who transformed existing conceptions of both a natural system and the animal economy. So instead of contrasting a Latourian history of networks that are continually extended with a Foucauldian history of discontinuities in forms of thought, we should see changing forms of thought as a consequence of attempts to extend a network of statements, things and phenomena as far as possible. ${ }^{27}$

Latour, then, is right when he asks us to take the notion of scientific revolutions with a grain of salt. ${ }^{28}$ Cuvier, no doubt, changed the notion of what was involved in natural history, but he was not a revolutionary who was simply breaking away from orthodoxy. What we need is a more subtle formulation of the kind of problem that he and other naturalists attempted to solve: to extend a network of statements, things and phenomena, there are not only many things that one should maintain, but also a few things that should be given up. For $\mathrm{Cu}$ vier, as we have seen, it was all-important to maintain the notion of the functional integrity of the animall body as the foundation of both the laws of animal 
organization and a natural system of classification, and so he was willing to give up the old idea of continuity between forms. Geoffroy"s work, however, clearly shows that in extending a network there was more than one way that a naturalist could go. In his attempts to establish universal laws of animal form, unity of type appeared to be the notion that he most wished to maintain. Thus, Geoffroy sacrificed a traditional concern with the more obvious similarities in regard to form or function and created a new system of alliances in which anatomy, embryology and the study of malformations became "indissolubly united", ${ }^{29}$

Of course, the idea that scientists are continually seeking to relate different points of view will sound familiar, especially to philosophers of science. In their terms, all we are talking about here is the aim of science to enlarge the scope of theories as far as possible. Moreover, in his analysis of Cuvier's work, Foncault has also put forward the idea that Cuvier established a relation between notions that originally were distinct, namely, the principle of subordination and a conception of animal organization. So what is the particular value of my Latourian account? First of all, it is clear that Latour's conception of networks involves much more than just the ideas and theories which philosophers of science tend to talk about. From a Latourian point of view, extending a network means tying together many heterogeneous elements: conceptions, interests, institutions, things, people, etc. Thus, we have seen that Cuvier's reform of classification in zoology was not only a question of aligning very different ideas - the notions of system and of animal economy - but also of aligning very different groups of practitioners - naturalists, anatomists and physiologists. To succeed, Cuvier created an elaborate collection of anatomical preparations, established techniques which enhanced the visibility of animal organization, and sought to relate internal characteristics indicating natural groups to external characteristics that for naturalists would be easy to identify. ${ }^{30}$

No doubt, Foucault's archaeological analysis also reaches further than ideas or theories. But in discussing how naturalists established relations between words and things, Foucault focuses his analysis on the rules of a discursive practice, rules which imply an invisible power restraining people in the way they speak and act towards the world about them. In his view, it is only when a new discursive practice arises, when a new restraining power manifests itself in the way people think and name, that words and things will be related in a new way. From a Latourian perspective, however, the ability or power to relate many heterogeneous elements depends crucially on means through which those elements may be mobilized, stabilized and combined. Thus I have shown how Linnaeus's success depended on a variety of means which allowed him to produce ever more simplified inscriptions, and how naturalists like Cuvier and Geoffroy succeeded in transforming the practice of zoological classification by 
establishing means which allowed them to make visible what for naturalists had so long remained invisible. ${ }^{31}$

The means through which scientists attempt to tie together many different elements are, indeed, as heterogeneous as these elements themselves. We may think of material means, like the methods of preservation used by naturalists to protect specimens in a cabinet, but also of rhetorical, social and political means. Thus, in the article mentioned above, Outram relates Cuvier's ability to emerge as the leading French naturalist of his day to many different resources: the sheer scale of his undertakings, his expertise as a practical anatomist, his appropriation of the many different ideas available in his intellectual environment, and the use of his political and social power. ${ }^{32}$ But, from a Latourian point of view, it was not so much a question of political and social power added to Cuvier's expertise as a scientist. On the contrary, Cuvier's inside world of esoteric scientific activity crucially depended, as we have seen, on the creation of an outside world of many different allies. ${ }^{33}$ Yet, without denying the heterogeneity of the means through which networks are extended, there are good reasons to emphasize, as I have done in my own Latourian analysis, the concrete, practical means through which naturalists succeeded in mobilising ever more things and phenomena in favour of their statements. For one thing, as Latour has pointed out in Science in Action, what we call "scientists" are simply those people who are subtle enough to include in their "Machiavellian" search for alliances not only human beings, but also non-human elements, like plants, animals, correlations and connections. ${ }^{34}$

The crucial importance of the concrete, practical means through which scientists mobilise resources contrasts sharply, as we have seen, with Foucault's emphasis on forms of thought. For Foucault there always are bounds to the possibilities of thought in any particular period in history, that is, there always is a particular "space" within which scientists have to move. For a Latourian observer, however, the problem is not what can, or cannot, possibly be thought, but how to make one's ideas stronger than those of others. Hence, the crucial importance of the means or tools which allow scientists to enhance the credibility of statements by relating their ideas to ever more statements, things and phenomena. Scientists, then, do not move within one particular space, they move through networks that are in between many different spaces. 


\section{References}

1. Both the transformation of natural history and the work of Cuvier are discussed by Foucault as part of a more comprehensive analysis in which he traces the emergence of the so-called modern episteme in the development of three different fields of study: labour, life and language. See chapters 7 an 8 of The Order of Things.

2. In The Order of Things Foucault does not aim at an explanation of the changes he describes. His archaeology allows him to establish fundamental discontinuities in the history of thought, but leaves open the question of how these changes have been caused.

3. Latour, 1988.

4. Chapter II, p. 52 .

5. Chapter TV, p. 110. See for Adanson's discussion of systems Stafleu, 1963, section 4.

6. Ibid., pp. 104-106. See also Outram, 1986, especially pp. 333-340.

7. Chapter V, pp. 139-140.

8. Daudin, 1926b, chapter 8, pp. 3-12.

9. Chapter IV, pp. 121-123. See also Cross, 1981.

10. See for an interesting description of the means through which Cuvier established this visibility: Daudin, 1926b, chapter 1, pp. 89-102.

11. Chapter V, pp. 143-144.

12. Albury, 1977; Cross, 1981.

13. Figlio, 1976. See also Outram, 1986, pp. 324-333. The idea of the interrelatedness of organs was not new indeed, as becomes clear from Frederic Holmes comment that "the concept that organs are interconnected in functional systems is at least as old as Aristotle's description of the heart and blood vessels as a system serving the general functions of nutrition and sensation". See Holmes, 1977, p. 218.

14. Chapter V, pp. 146-149.

15. Ibid, pp. 149-152.

16. Foucault, $1970 \mathrm{a}, \mathrm{p} .231$.

17. See the discussion added to Foucault, 1970 b, especially pp. 73-75.

18. Chapter V, pp. 163-165.

19. Latour, 1986, p. 25. A very interesting document in this respect is Geoffroy"s article on "Nature". See Geoffroy, 1830a, especially pp. 11-12.

20. Chapter V, pp. 160-162.

21. Laurent, 1977.

22. See Geoffroy's words quoted by Laurent. Ibid., p. 47. See also my chapter V, p. 162 .

23. In Geoffroy's biography, Isidore Geoffroy Saint-Hilaire nicely describes the great divide between all those naturalists who ever pondered the idea of unity of type and Geoffroy in whose work we find its "rational demonstration". For the author, 
however, it seems to be evident that this demonstration depended on Geoffroy's mind rather than on his means. See I. Geoffroy Saint-Hilaire, 1847, especially the fourth section of chapter 5 and the first three sections of chapter 8.

24. Outram, 1986.

25. This point is made in: Foucault, $1970 \mathrm{~b}$.

26. Outram, 1986, p. 366.

27. We might also say that discontinuities appear on the level of ready made science as a result of continuity on the level of science in action. See for the distinction between "ready made science" and "science in action": Latour, 1987, Introduction.

28. Latour, 1988, p. 24 .

29. I(sidore) Geoffroy Saint-Hilaire, 1847, p. 259. For the notion of "systems of alliances" see Latour, 1987, pp. 121-124.

30. For a very interesting account of the impact of Cuvier's work on the practice of classification, see Daudin, 1926b, chapter 1, pp. 70-89.

31. It was, as we have seen, precisely on this point that Buffon failed.

32. Outram, 1986, p. 368 .

33. See my account of Cuvier's network building activities in chapter $\mathrm{V}, \mathrm{pp}$. 140-142, and also my discussion in the concluding section of chapter IV, pp. 127-128.

34. Latour, 1987, pp. 124-125. 


\section{BIBLIOGRAPHY}

Albury, W.R., 'Experiment and Explanation in the Physiology of Bichat and Magendie', Studies in History of Biology 1, 1977, 47-131.

Albury, W.R., D.R. Oldroyd, 'From Renaissance Mineral Studies to Historical

Geology, in the Light of Michael Foucault"s "The Order of Things"', British Journal of the History of Science 10, 1977, 187-215.

Allen, D.E., The Naturalist in Britain. A Social History, Harmondsworth, Penguin Books, 1976.

Appel, T.A., The Cuvier-Geoffroy Debate. French Biology in the Decades before Darwin, New York, Oxford University Press, 1987.

Balan, B., L'orde et le temps: l'anatomie comparée et l' histoire des vivants au XIXe siècle, Paris, Vrin, 1979.

Bertin, L., "Buffon, Homme d"Affaires", in L. Bertin (et al.), Buffon (Les Grand Naturalistes Français), Paris, Le Musée National d'Histoire Naturelle, 1952, 87-104.

Boerman, A.J., 'Linnaeus and the Scientific Relations between Holland and Sweden', in G. Broberg (ed.), Linnaeus. Progress and Prospects in Linnaean Research, Stockholm, Almquist and Wiksell, 1980, 43-56.

Buffon, G.L. Leclerc de (et al.), Histoire naturelle, générale et particulière, avec la description du Cabinet du roi, Paris, Imprimerie Royale, 1749-1789, 31 volumes.

Burkhardt, R.W., The Spirit of System: Lamarck and Evolutionary Biology, Cambridge Mass., Harvard University Press, 1977.

Caron, J. " "Biology" in the Life Sciences: A Historiographical Contribution", History of Science 26, 1988, 223-268.

Carus, J.V., Geschichte der Zoologie bis auf Johannes Müller und Charles Darwin, München, Oldenburg, 1872.

Coleman, W., Georges Cuvier, Zoologist: a study in the history of evolution theory, Cambridge Mass., Harvard University Press, 1964.

Coleman, W., Biology in the nineteenth century. Problems of form, function and transformation, London, Cambridge University Press, 1977. 
Corsi,P., "Models and Analogies for the Reform of Natural History. Features of the French Debate 1790-1800', in W. Bernardi, A. La Vergata (eds, Lazzaro Spallanzani e la Biologia del Settecento. Teorie, Esperimenti, Istituzioni Scientifiche, Florence, Olschki, 1982.

Corsi, P.,The Age of Lamarck. Evolutionary Theories in France 1790-1830, Berkeley, University of California Press, 1988.

Cross, S., 'John Hunter, the animal economy, and late eighteenth-century physiological discourse', Studies in History of Biology 5, 1981, 1-110.

Cuvier, G., "Mémoire sur la structure inteme et externe, et sur les affinités des animaux. auxquels on a donné le nom de Vers', Décade philosophique 5, 1795a, 385-396.

Cuvier, G., 'Second Mémoire sur l'organisation et les rapports des animaux à sang blanc, dans lequel on traite de la structure des Mollusques et de leur division en ordre', Magasin encyclopédique 2, 1795b, 433-449.

Cuvier, G., Leçons d' anatomie comparée, C. Duméril (ed.) Vols. 1-2, 1800, G.L. Duvernoy (ed.) Vols. 3-5, 1805, Paris, Baudouin.

Cuvier, G., 'Sur un nouveau rapprochement à établir entre les classes qui composent le règne animal', Annales du Muséum d' Histoire Naturelle 19, 1812, 73-84.

Cuvier, G., Le règne animal distribué d' après son organisation pour servir de base à l' histoire naturelle des animaux et d' introduction à l' anatomie comparée, Paris, Déterville, 1817,4 volumes.

Cuvier, G., 'Nature',Dictionnaire des sciences naturelles 34 , Strasbourg-Paris, Levrault, 1825, 261-268.

Cuvier, G., 'Première Argumentation ou considérations sur les mollusques, et en particulier sur les céphalopodes', in E. Geoffroy Saint-Hilaire, Principes de Philosophie Zoologique, discutés en mars 1830 , au sein de l'Académie Royale des Sciences, Paris, Pichon et Didier, 1830, 53-72.

Cuvier, G., Lettres de Georges Cuvier à C.H. Pfaff, 1788-1792, sur l' histoire narurelle, la politique, et la littérature. Traduites de l'allemand par Louis Marchant, Paris, Masson, 1858.

Daudin, H., De Linné à Jussieu. Les méthodes de la classification et l' idée de série du Botanique et du Zoologie (1740-1790), Paris, Alcan, 1926a.

Daudin, H., Cuvier èt Lamarck. Les classes zoologiques et l' idéee de sếrie animale (1790-1830), Paris, Alcan, 1926b.

Dechambre, Ed., 'L'article des chiens dans 1'Histoire Naturelle', in L. Bertin (et al.), Buffon (Les Grand Naturalistes Français), Paris, Le Musée National d'Histoire Naturelle, 1952, 157-166.

Diderot, D., J. Le Rond d'Alembert (eds.), Encyclopédie ou dictionnaire raisonné des sciences, des arts et des métiers, Facsimile of the first edition of 1751-1780, Stuttgart-Bad Cannstadt, Frommann, 1966. 
Eisenstein, E.L., The Printing Press as an Agent of Change: Communications and cultural transformations in early-modern Europe, Cambridge, Cambridge University Press, 1979.

Eriksson, G., The Botanical Success of Linnaeus. The Aspect of Organization and Publicity', in G. Broberg (ed.), Linnaeus. Progress and Prospects in Linnaean Research, Stockholm, Almquist and Wiksell, 1980, 57-66.

Eriksson, G., 'Linnaeus the Botanist', in T. Frängsmyr(ed)., Linnaetus: the man and his work, Berkeley, University of California Press, 1983, 63-109.

Farber, P.L., 'Buffon and the concept of species', Journal of the History of Biology 5 , 1972, 259-284.

Farber, P.L., 'Buffon and Daubenton: Divergent traditions within the Histoire naturelle', Isis 66, 1975, 63-74.

Farber, P.L., The Emergence of Ornithology as a Scientific Discipline: 1760-1850, Dordrecht, Reidel, 1982a.

Farber, P.L., 'Research Traditions in Eighteenth Century Natural History', in W. Bernardi, A. La Vergata(eds.), Lazzaro Spallanzanie la Biologia del Settecento. Teorie, Esperimenti, Istituzioni Scientifiche, Florence, Olschki, 1982b, 397-403. Farber, P.L., "The Transformation of Natural History in the Nineteenth Century", Journal of the History of Biology 15, 1982c, 145-152.

Figlio, K.M., 'The Metaphor of Organization: An Historiographical Perspective on the Bio-Medical Sciences of the Early Nineteenth Century', History of Science 14, 1976, 17-53.

Fleck, L., Genesis and Development of a Scientific Fact, Chicago, University of Chicago Press, 1979 (first published in German in 1935).

Flourens, P.,Recueil des Eloges Historiques. Lus dans les séances publiques de $l$ 'Académie des Sciences, Paris, Garnier Frères, 1856-1857, 2 volumes.

Foucault, M., The Order of Things. An Archaeology of the Human Sciences, London, Tavistock Publications, 1970a.

Foucault, M., 'La situation de Cuvier dans l'histoire de la biologie', Revue d' Histoire des Sciences 23, 1970b, 63-69, followed by a discussion: 70-72.

Foucault, M., The Archaeology of Knowledge, London, Tavistock Publications, 1977.

François, Y., 'Buffon au Jardin du Roi', in L. Bertin (et al.), Buffon (Les Grand Naturalistes Français), Paris, Le Musée National d'Histoire Naturelle, 1952, 105-124.

Geoffroy Saint-Hilaire, E., G. Cuvier, 'Mémoire surune nouvelle division des mammifères et sur les principes qui doivent servir de base dans cette sorte de travail', Magasin Encyclopédique 2, 1795, 164-190. 
Geoffroy Saint-Hillaire, E., 'Mémoire sur l'anatomie comparée des organes électriques de la rais torpille, du gymnote engourdissant, et du silure trembleur', Annales du Muséum d' Histoire Naturelle 1, 1802, 392-407.

Geoffroy Saint-Hilaire, E., "Premier mémoire sur les poissons, où l'on compare les pièces osseuses de leurs nageoires pectorales avec les os de l'extrémité antérieurs des autres animaux à vertè bres, Annales du Muséum d' Histoire Naturelle $9,1807 \mathrm{a}, 357-372$.

Geoffroy Saint-Hilaire, E., 'Troisième mémoire sur les poissons, où l'on traite de leur sternum sous le point de vue de sa détermination et de ses formes générales', Annales du Muséum d' Histoire Naturelle 10, 1807b, 87-104.

Geoffroy Saint-Hilaire, E., 'Considérations sur les pièces de la tête osseuse des animaux vertébrés, et particulièrement sur celles du crâne des oiseaux', Annales du Muséum d' Histoire Naturelle 10, 1807c, 342-365.

Geoffroy Saint-Hilaire, E.,Philosophie anatomique,Paris, Méquignon-Marvis, $1818-1822,2$ volumes.

Geoffroy Saint-Hilaire, E., "Nature', Encyclopédie moderne, ou dictionnaire abrégé des hommes et des choses 17, Brussels, Lejeune, 1830a, 5-15.

Geoffroy Saint-Hilaire, E.,Principes de Philosophie Zoologique, discutés en mars 1830, au sein de l'Académie Royale des Sciences, Paris, Pichon et Didier, $1830 \mathrm{~b}$. Geoffroy Saint-Hilaire, I(sidore)., Vie, Traveaux et Doctrine scientifique d'Etienne Geoffroy Saint-Hilaire, Paris, Bertrand, 1847.

Gillispie, C.C., 'The Encyclopédie and the Jacobin Philosophie of Science', in M. Clagett(ed.), Critical Problems in the History of Science, Madison, University of Wisconsin Press, 1957, 255-290.

Gillispie, C.C., Science and Polity in France at the End of the Old Regime, Princeton, Princeton University Press, 1980.

Golinski, J.V., 'Science in the Enlightenment', History of Science 24, 1986, 411-424. Goodman, D., Buffon's Natural History, Open University Press, Milton Keynes, 1980.

Holmes, F.L., 'Conceptual history. A Review of François Jacob, The Logic of Life, A History of Heredity', Studies in History of Biology 1, 1977, 209-218. Hoppe, B., 'Umbildungen der Forschung in der Biologie im 19. Jahrhundert, in A. Diemer (ed.), Konzeption und Begriff der Forschung in den Wissenschaften des 19. Jahrhunderts, Meisenhaim am Glan, Hain, 1978, 104-188.

Jacob, F., The Logic of Life. A History of Heredity, New York, Pantheon Books, 1973. Jordanova, L.J., 'Towards the Light? Science, Politics and the Enlightenment', European Studies Review 12, 1982, 479-488. 
Larson, J.L., Reason and Experience: The Representation of Natural Order in the work of Carl von Linné, Berkeley, University of California Press, 1971.

Larson, J.L., 'An Alternative Science, Linnaean Natural History in Germany, 1770-1790, Janus 66, 1979, 267-283.

Latour, B., "Visualization and Cognition: thinking with eyes and hands ${ }^{3}$, Knowledge and Society 6, 1986, 1-40.

Latour, B., Science in Action. How to follow scientists and engineers through so. ciety, Open University Press, Milton Keynes, 1987.

Latour, B., 'A Relativistic Account of Einstein's Relativity', Social Studies of Science 18, 1988, 3-44.

Laurent, G., 'Le cheminement d'Etienne Geoffroy St. Hilaire vers un transformisme scientifique", Revue d' Histoire des sciences 30, 1977, 43-70.

Lenoir, T., 'The Göttingen School and the Development of Transcendental Naturphilosophie in the Romantic Era', Studies in History of Biology 5, 1981, 111-205.

Lenoir, T., The Strategy of Life. Teleology and Mechanics in Nineteenth-Century German Biology, Dordrecht, Reidel, 1982.

Lepenies, W., Das Ende der Naturgeschichte. Wandel Kultureller Selbstverständlichkeiten in der Wissenschaften des 18. und 19.Jahrhunderts, München, Hanser Verlag, 1976.

Linnaeus, C., Systema Naturae (1735), Fascimile of the First Edition with an Introduction and first English translation of the "Observations" by Dr. M.S.J. Engel-Ledeboer and Dr. H. Engel, Nieuwkoop, de Graaf, 1964.

Lönnberg, E., Carl von Linné's Bedeutung als Naturforscher und Artz, Jena, Gustav Fischer, 1909.

Lyon, J., P.R. Sloan (eds.), From Natural History to the History of Nature: Readings from Buffon and his Critics, Notre Dame Ind., University of Notre Dame Press, 1981.

Outram, D., Georges Cuvier: Vocation, Science and Authority in Post-Revolutionary France, Manchester, Manchester University Press, 1984.

Outram, D., "Uncertain Legislator: George Cuvier's laws of nature in their intellectual context', Journal of History of Biology 19, 1986, 323-368.

Piveteau, J. (ed.), Oeuvres philosophiques de Buffon, Paris, Presse Universitaires de France, 1954.

Roger, J., Les Sciences de la Vie dans la Pensée Française du XVIIle Siècle: La Génération des Animaux de Descartes à l'Encyclopédie, Paris, Colin, 1963.

Roger, J., 'The Living World', in G.R. Rousseau and R. Porter (eds.), The Ferment of Knowledge: Studies in the historiography of eighteenth-century science, 
Cambridge, Cambridge University Press, 1980, 255-283.

Rudwick, M.J.S., The Meaning of Fossils. Episodes in the History of Palaeontology, New York, Science History Publications, 1976.

Russel, E.S., Form and Function: A Contribution to the History of Animal Morphology, London, Murray, 1916.

Schmidt, K.P., "The "Methodus" of Linnaeus, 1736', The Journal of the Society for the Bibliography of Natural History 2, 1952, 369-374.

Secord, J.A., 'Natural History in Depth', Social Studies of Science 15, 1985, 181-200.

Sloan, P.R., 'John Locke, John Ray and the Problem of the Natural System', Journal of the History of Biology 5, 1972, 1-53.

Sloan, P.R., 'The Buffon-Linnaeus Controversy', Isis 67, 1976, 356-375.

Sloan, P.R., 'Buffon, German Biology, and the Historical Interpretation of Biological Species', British Journal of the History of Science 12, 1979, 109-153.

Smit, P., 'The Zoological Dissertations of Linnaeus', in G. Broberg (ed.), Linnaeus. Progress and Prospects in Linnaean Research, Stockholm, Almqvist and Wiksell, 1980, 118-136.

Stafleu, F.A., 'Adanson and his "Familles desPlantes"', in G.H.M. Lawrence (ed.), Adanson: the bicentennial of Michel Adanson's Famille des Plantes, Pittsburgh, Carnegie Institute of Technology Monograph Series, No. 1, 1963, 123-264.

Stafleu, F.A., Linnaeus and the Linnaeans. The spreading of their ideas in systematic botany, 1735-1789, Utrecht, Oosthoek, 1971.

Star, G.L., J.R. Griesemer, "Institutional Ecology, Translations and Boundary Objects: Amateurs and Professionals in Berkeley's Museum of Vertebrate Zoology, 1907-39', Social Studies of Science 19, 1989, 387-420.

Stevens, P.F., 'Haily and A.P. Candolle: Crystallography, Botanical Systematics and Comparative Morphology, 1780-1840',Joumal of the History of Biology $17,1984,49-82$.

Wohl, R., 'Buffon and his Project for a New Science', Isis 51, 1960, 186-199. Wood, P.B., 'Buffon's reception in Scotland: The Aberdeen connection', Annals of Science 44, 1987, 169-190. 


\section{PLANTEN, DIEREN EN FORMULES}

\section{De natururlijke historie in het licht van Latour's Wetenschap in Actie en Foucault's De Woorden en de Dingen}

\section{Samenvatting}

Dit proefschrift bevat drie verhalen. Het eerste verhaal is een geschiedenis van de natuurlijke historie, in het bijzonder van het wetenschappelijk classificeren van planten en dieren in de achttiende en vroeg negentiende eeuw. De beide andere verhalen zijn het resultaat van een beschouwing van deze geschiedenis vanuit twee sterk verschillende gezichtspunten die ik in dit proefschrift met elkaar confronteer.

Een van deze gezichtspunten heb ik ontleend aan het werk van de Franse filosoof Michel Foucault. Evenals vele moderne wetenschapshistorici heeft Foucault in zijn werk sterk de nadruk gelegd op het bestaan van discontinuîteiten in de historische ontwikkeling van wetenschappelijke kennis. Dat wil zeggen, in plaats van een voortdurende en cumulatieve groei van kennis laat de ontwikkeling van wetenschap van tijd tot tijd diepgaande breuken zien in de manier waarop de wereld wordt gekend. Foucault heeft deze gedachte op een specifieke manier uitgewerkt in zijn boek De Woorden en de Dingen. Daarin laat hij zien hoe halverwege de zeventiende eeuw onze Westerse cultuur een radicale verandering onderging en vanaf dat moment beheerst werd door een specifieke wijze van classificerend denken. Foucault spreekt van het ontstaan van een klassieke "epistèmè" en ziet het streven naar ordening in de natuurlijke historie van de zeventiende en achttiende eeuw als een van de typische verschijningsvormen daarvan. Wanneer aan het begin van de negentiende eeuw de klassieke manier van denken plaats maakt voor een radicaal nieuwe, moderne epistèmè, verdwijnt ook de natuurlijke historie om plaats te maken voor een biologie. Aldus formuleert Foucault op eigenzinnige wijze een gedachte die ook bij veel historici van de biologie te vinden is: planten en dieren zijn in de loop der eeuwen vanuit radicaal verschillende gezichtspunten bestudeerd en van een biologie als levenswetenschap kan daarbij pas vanaf het begin van de negentiende eeuw gesproken worden.

Het werk van de Franse wetenschapsonderzoeker Bruno Latour, en in het bijzonder zijn boek Wetenschap in Actie, heeft mij geïnspireerd tot een geheel andere analyse van de lotgevallen van de natuurlijke historie. Niet het abstracte 
denken van wetenschappers staat in Latour's werk centraal, maar de concrete en zeer uiteenlopende middelen waarvan wetenschappers zich bedienen in hun streven om uitspraken zo geloofwaardig mogelijk te maken. Het werk van Latour weerspiegelt daarbij de groeiende belangstelling in het moderne wetenschapsonderzoek voor de praktijken waarin wetenschappelijke kennis wordt gemakk. Vanuit een Latouriaans gezichtspunt vormden de classificatieschema's van de achttiende eeuwse natuurlijke historie slechts het topje van de ijsberg. Deze schema's waren slechts een middel naast vele andere middelen - zoals het gebruik van schepen, van legers, van conservatiemethoden, van de drukpers waarmee planten en dieren op steeds grotere schaal konden worden bijeengebracht, bewaard, beschreven, vergeleken en geordend. Juist dergelijke middelen, aldus Latour, stellen wetenschappers in staat om beweringen op steeds grotere schaal te koppelen aan dingen en verschijnselen en om zo hun beweringen geloof waardiger te maken dan die van anderen. Vanuit dit Latouriaanse gezichtspunt moeten we de lotgevallen van de natuurlijke historie dan ook niet verbinden met grootse omwentelingen in het denken, maar met al die kleine en veelvormige vernieuwingen die het mogelijk maakten om de mobiliteit, de stabiliteit en de combineerbaarheid van planten en dieren voortdurend te verhogen.

$\mathrm{Bij}$ de confrontatie van deze zeer verschillende gezichtspunten ben ik uitgegaan van Latour's advies om, in onze pogingen om wetenschap te doorgronden, onze aandacht altijd eerst te richten op de middelen waarmee uitspraken, dingen en verschijnselen worden aaneengesmeed in een reeks van opeenvolgende abstracties. Op deze manier blijkt het mijns inziens inderdaad heel goed mogelijk om de classificatieschema's van de natuurlijke historie, die in Foucault's analyse verschijnen als de uitdrukking van een specifieke manier van denken, te begrijpen als resultaat van een eindeloze keten van heterogene activiteiten waarin planten en dieren werden gemobiliseerd, gestabiliseerd en gecombineerd. Maar kunnen we op deze manier nu ook de radicale veranderingen begrijpen in de logica van het classificeren die volgens Foucault aan het begin van de negentiende eeuw het lot van de natuurlijke historie bezegeld hebben? Mijn antwoord op deze vraag luidt bevestigend. Wat ik daarbij probeer te laten zien is dat juist naarmate naturalisten er in slaagden om steeds weer nieuwe middelen te vinden waarmee een toenemend aantal planten en dieren kon worden gecombineerd in een allesomvattend classificatiesysteem, ze ook steeds weer voor de keus werden gesteld om bepaalde vertrouwde manieren van denken op te geven. Het Latouriaanse gezichtspunt sluit dus de door Foucault besproken veranderingen in manieren van denken allesbehalve uit. Vanuit dit gezichtspunt, echter, verschijnen deze veranderingen niet als manifestatie van geheimzinnige, en weinig tastbare, epistemische breuken in de geschiedenis van het denken, maar als resultaat van een geschiedenis van zeer uiteenlopende concrete middelen 
waarmee in de natuurlijke historie netwerken van uitspraken, dingen en verschijnselen voortdurend werden uitgebreid.

Een groot deel van dit proefschrift is gewijd aan een geschiedenis van de natuurlijke historie in de achttiende en vroeg negentiende eeuw die me in staat heeft gesteld om de gezichtspunten van Foucault en Latour op specifieke wijze met elkaar te confronteren. Daarbij heb ik in deze geschiedenis geprobeerd om me zoveel mogelijk tussen verschillende gezichtspunten te bewegen. Met andere woorden, mijn verhaal is een poging om zowel aan de geschiedenis van ideeën, als van praktijken en instituties in de natuurlijke historie recht te doen. In het bijzonder beschrijf ik (1) de wijze waarop planten en dieren werden verzameld in tuinen, in herbaria, en in kabinetten of musea voor natuurlijke historie, (2) de verschillende manieren van doen en kijken belichaamd in de activiteiten van apothekers, van artsen, en van naturalisten in kabinetten of in het veld, (3) de kennistheoretische idealen in termen waarvan deze activiteiten werden gerechtvaardigd, en (4) sommige van de systemen, theorieën en concepten zoals die in de geschriften van individuele naturalisten te vinden zijn. Ik heb bovendien geprobeerd om deze verschillende verhaallijnen met elkaar te verbinden door de activiteiten van naturalisten te beschouwen als te zijn betrokken in een proces van abstractie: collecties van planten en dieren, manieren van doen en kijken, en kennistheoretische idealen verschijnen dan als bepalend voor de manier waarop in de natuurlijke historie aan abstracties zoals "typen" en "wetten" is vorm gegeven.

In het eerste deel van dit proefschrift staat centraal de manier waarop de natuurlijke historie zich in de achttiende eeuw ontwikkelde tot een ware wetenschap van het classificeren. Planten en dieren uit alle delen van de wereld werden op grote schaal verzameld en beschreven en daarbij kwamen kwesties van orde en naamgeving hoog op de agenda te staan. Door sommigen werden deze kwesties vooral als een praktisch probleem beschouwd. Vanuit dat gezichtspunt gezien was een classificatiesysteem niet meer dan een handig hulpmiddel bij het identificeren van planten en dieren. De meeste naturalisten echter, zagen het classificeren als het kernprobleem van een wetenschappelijke natuurlijke historie, juist omdat het in hun ogen om meer ging dan een praktische oplossing voor een praktisch probleem. Een systeem zou ook uitdrukking moeten geven aan de natuurlijke stand van zaken. Maar wat moest daarbij als de natuurlijke stand van zaken worden beschouwd, en hoe zou kennis over die stand van zaken kunnen worden verkregen? Over deze vragen bestonden in de zeventiende en achttiende eeuw grote verschillen van mening.

Een wel zeer duidelijke illustratie daarvan levert de vergelijking van het werk van twee van de meest bekende naturalisten van de achttiende eeuw: Lin- 
naeus en Buffon. Voor Linnaeus werd de naturlijke orde in het planten- en dierenrijk belichaamd door een hiërarchisch systeem waarin alle planten en dieren waren ondergebracht in klassen, ordes, genera, en soorten, en waarbij elk van deze groepen op elk niveau was gedefinïeerd in termen van een beperkt aantal essentiële kenmerken. Buffon, daarentegen, zag een dergelijk systeem als een onduldbare abstractie van een natuurlijke werkelijkheid, een werkelijkheid die alleen maar gekend zou kunnen worden door een volledige beschrijving van plant en dier en door de werkelijke, genealogische relaties tussen individuen in kaart te brengen. Buffon's aanpak werd, in tegenstelling tot die van Linnaeus, echter nauwelijks aanvaard. Dit onderstreept, zoals ik in hoofdstuk drie laat zien, het Latouriaanse adagium dat we bij het bestuderen van de wetenschap onze aandacht niet op het denken, maar op het doen moeten richten. Linnaeus' succes berustte namelijk niet op de wijze waarop hij zijn systeem rechtvaardigde, maar vooral op de middelen die hij introduceerde - zoals een rigoreus gestandaardiseerde manier van beschrijven - waarmee de combineerbaarheid van planten in een classificatiesysteem aanzienlijk werd verhoogd. Buffon faalde, niet vanwege onbegrip voor zijn ideeën, maar vooral omdat hij niet de middelen wist te vinden waarmee de genealogische relaties tussen individuen in heden en verleden zouden kunnen worden opgespoord.

Toch blijkt op grond van mijn analyse in het eerste deel van dit proefschrift een Latouriaanse interpretatie van de abstraherende activiteiten van naturalisten niet geheel bevredigend. Wat naturalisten deden was duidelijk meer dan alleen het creëren van abstracties. Ze waren ook verwikkeld in een strijd over de betekenis die aan deze abstracties moest worden toegekend: waren classificatiesystemen er alleen om het geheugen te ontlasten of drukten ze ook een natuurlijke stand van zaken uit? In de ogen van veel naturalisten voldeed het systeem van Linnaeus, hoe bruikbaar ook in de praktijk, niet aan het ideaal van een natuurlijk systeem. Historici van de biologie zien daarbij het einde van de achttiende eeuw vaak als een keerpunt in de geschiedenis van het classificeren, juist omdat vanaf dat moment het denken over een natuurlijk systeem het doen van naturalisten in hoge mate ging bepalen. En het is in dit verband dat Foucault spreekt van een epistemische breuk die het einde betekende van de klassieke natuurlijke historie en de voorwaarden schiep voor het ontstaan van een moderne biologie. Hoe deze geschiedenis te begrijpen vanuit een Latouriaans gezichtspunt?

Deze vraag wordt beantwoord in het tweede deel van dit proefschrift waarin ik het bovengenoemde thema van de transformatie van de natuurlijke historie centraal heb gesteld. Mijn blik concentreert zich daarbij op het werk van Franse, in het bijzonder Parijse, naturalisten die aan het einde van de achttiende en het begin van de negentiende eeuw in deze transformatie van de natuurlijke historie 
een cruciale rol hebben gespeeld. De meeste van deze naturalisten waren het er over eens dat een natuurlijk classificatie-systeem alleen dan binnen bereik zou komen wanneer, in plaats van een beperkt aantal willekeurig gekozen eigenschappen, het geheel aan kenmerken van een plant of dier in ogenschouw genomen werd. Dit betekende dat, in het bijzonder in de zoologie, classificaties niet op de meest opvallende, uiterlijke, maar vooral ook op innerlijke kenmerken zouden moeten worden gebaseerd. Kennis van de inwendige anatomie was in de achttiende eeuw echter voornamelijk voorbehouden aan artsen-anatomen die meer in ziekten dan in zoölogische classificaties waren geinteresseerd Naturalisten daarentegen richtten zich bij het classificeren wooral op uiterlijke kenmerken, niet alleen omdat deze gemakkelijk te herkennen waren, maar ook omdat zij in hun werk voornamelijk waren aangewezen op collecties in kabinetten voor natuurlijke historie waarin schelpen, huiden, tanden en nagels zich gemakkelijker lieten verzamelen en bewaren dan weekdieren of ingewanden. Het ideaal van een natuurlijk systeem was voor de verwezenlijking daarvan dus afhankelijk van kennis die in de achttiende eeuw met twee zeer verschillende praktijken verbonden was: die van artsen-anatomen in de snijzaal en die van naturalisten in een kabinet.

De Franse naturalist Cuvier is bij uitstek degene geweest die aan het einde van de achttiende eeuw deze praktijken tot elkaar heeft gebracht en die vervolgens, in de ogen van zijn tijdgenoten, een natuurlijk systeem in de zoölogie aanzienlijk dichterbij wist te brengen. Zijn werk beschrijf ik naast dat van zijn collega, en latere tegenstrever, Geoffroy Saint-Hilaire, die in het begin van de negentiende eeuw naturalisten eveneens in hoge mate geinspireerd heeft tot een nieuwe kijk op de relaties in het dierenrijk. Ook in Foucault's analyse van het lot van de natuurlijke historie is Cuvier een centrale figuur. Cuvier, aldus Foucault, gaf in zijn werk gestalte aan een nieuwe, moderne epistèmè waarin de aandacht verschoven is van de zichtbare buitenkant van de levensvormen naar het binnenste, waar het onzichtbare leven verborgen ligt. Juist in deze verschuiving van de blik werd het lot van de klassieke natuurlijke historie bezegeld en school de mogelijkheid van het ontstaan van een biologie. Deze verschuiving van de blik vinden we volgens Foucault ook terug in het werk van Geoffroy die, net zo als Cuvier, overeenkomsten probeerde te vinden welke onzichtbaar onder het oppervlak van levensvormen verscholen lagen.

In het slothoofdstuk van dit proefschrift confronteer ik Foucault's analyse opnieuw met een aan het werk van Latour ontleend gezichtspunt. Mijn stelling is dat het werk van Cuvier niet door een verschuiving van de blik gekenmerkt werd, maar door een poging om verschillende blikrichtingen met elkaar te verbinden. Alleen door het gezichtspunt van naturalisten te verbinden met dat van fysiologen en anatomen zou volgens Cuvier een werkelijk geloof waardige 
classificatie kunnen worden bereikt. Cuvier slaagde omdat hij inderdaad ook de middelen wist te vinden waarmee een dergelijke verbinding tot stand kon worden gebracht, waarmee, anders gezegd, een netwerk van uitspraken, dingen en verschijnselen daadwerkelijk kon worden uitgebreid. Was Cuvier uit op een radicale breuk met bestaande manieren van denken? Verre van dat Zijn vraag was juist hoe zoveel mogelijk bestaande gezichtspunten in een classificatie zouden kunnen worden behouden.

Toch is er ook vanuit dit Latouriaanse gezichtspunt geen reden om te ontkennen dat Cuvier's werk leidde tot een breuk met onder naturalisten diep gekoesterde beelden en overtuigingen. Zo kon het aloude beeld van continuîteit in de natuur, gesymboliseerd in de voorstelling van een ononderbroken reeks van vormen, in Cuvier's ogen geen genade vinden zodra naast de uiterlijke schijn ook de interne anatomie van dieren serieus genomen werd. Cuvier's probleem was echter veel subtieler dan dat van een revolutionair die simpelweg breekt met bestaande ideeën: wie er naar streeft om een netwerk van uitspraken, dingen en verschijnselen zo ver mogelijk uit te breiden, ontkomt er niet aan om daarvoor ook het een en ander op te geven. Een vergelijking van het werk van Cuvier met dat van Geoffroy leert ons daarbij dat er voor een naturalist meer dan een manier was waarop een netwerk kon worden uitgebreid. Op heel verschillende manieren braken Cuvier en Geoffroy beide met bestaande ideeën, maar wat zij daarbij opgaven werd in de eerste plaats bepaald door al het andere dat zij wilden behouden. In dit proefschrift laat ik dus niet alleen zien dat kenmerken van de natuurlijke historie die door Foucault aan een onderliggende epistèmè worden toegeschreven heel goed begrepen kunnen worden als het resultaat van het concrete werk van het maken van abstracties. Ook wordt duidelijk hoe veranderingen in manieren van denken die Foucault toeschrijft aan het op geheimzinnige wijze ontstaan van een radicaal nieuwe epistèmè op Latouriaanse wijze kunnen worden verklaard vanuit een dynamiek van behouden en opgeven die aan de uitbreiding van netwerken verbonden is. 
8 


\section{CURRICULUM VITAE}

Dirk Stemerding, geboren op 18 april 1951 te Amsterdam

1963 - 1968: HBS-B te Groningen

1968 - 1975: Biologiestudie aan de Rijksuniversiteit Groningen met hoofdvak microbiologie en bijvakken fytomorfologie en polemologie

1976 - 1980: Wetenschappelijk medewerker voor Wetenschap en Samenleving aan de subfaculteit Biologie van de Rijksuniversiteit Groningen

Sinds 1980: Universitair docent verbonden aan de vakgroep Filosofie van Wetenschap en Techniek van de Faculteit Wijsbegeerte en Maatschappijwetenschappen, Universiteit Twente. 